UNIVERSIDADE DE SÃO PAULO

FACULDADE DE FILOSOFIA LETRAS E CIÊNCIAS HUMANAS

DEPARTAMENTO DE GEORAFIA

Programa de Pós-graduação em Geografia Humana

\title{
ÉDEN: PARAIISO INDUSTRIAL EM SOROCABA OU PURGATÓRIO SOCIAL?
}

\author{
Michel Soares Rodrigues da Silva
}

Versão corrigida

São Paulo, 2011 
UNIVERSIDADE DE SÃO PAULO

FACULDADE DE FILOSOFIA LETRAS E CIÊNCIAS HUMANAS

DEPARTAMENTO DE GEORAFIA

Programa de Pós-graduação em Geografia Humana

\section{ÉDEN: PARAÍSO INDUSTRIAL EM SOROCABA OU PURGATÓRIO SOCIAL?}

Michel Soares Rodrigues da Silva

Dissertação de Mestrado desenvolvida no Programa de Pós-graduação em Geografia Humana, sob orientação da Prof ${ }^{\mathrm{a}}$ Dra Glória da Anunciação Alves

Versão corrigida "de acordo":

Versão corrigida

São Paulo, 2011 


\section{Agradecimentos:}

- à Professora Dra. Glória da Anunciação Alves pela oportunidade e contribuições acadêmicas;

- a todos os colegas do grupo de estudos nos momentos de reflexão: Adailton, Emerson, Nedir, Neide, Sandra, Gil, Paula e tantos outros;

- às pessoas que contribuíram com informações valiosas;

\section{Agradecimento especial:}

- aos meus pais, Teresinha e Sebastião (muitas lembranças) que me guiaram sutilmente na simplicidade;

- à minha esposa Cláudia que compartilhou momentos ótimos e alguns deles difíceis;

- aos meus filhos Matheus e Beatriz pela paciência e compreensão;

- às minhas irmãs Nazira e Nara;

- a todos que me apoiaram;

- a Deus por agraciar e iluminar meus caminhos 


\section{Resumo:}

Esta dissertação discute como ocorreu o processo de industrialização recente da cidade de Sorocaba a partir da desconcentração industrial da capital paulista em direção ao interior do Estado de São Paulo. Frente a essa realidade que ocorre a partir da década de 1970, a cidade de Sorocaba se organizou para receber essas indústrias destinando uma área da cidade que chamou de Zona Industrial com a função de abrigá-las. Nessa zona, constituída pelos bairros do Éden, Cajurú do Sul e Aparecidinha, a presente dissertação analisa as transformações mais recentes que ocorreram no bairro do Éden caracterizando alguns de seus aspectos históricos, sua relação com os agentes públicos e com as atividades industriais desenvolvidas. $O$ cotidiano da população é considerado como um aspecto relevante para compreender as transformações promovidas no espaço geográfico, tanto do bairro como do município, o que agrega não só as pretensões, os anseios da população local, bem como dos agentes públicos e privados, parceiros mais próximos em atingir a reprodução do capital em detrimento do bem estar social.

Palavras-chave: indústria, industrialização, Sorocaba, Éden, organização espacial 


\section{Abstract:}

This dissertation discuss how the recent industrialization process of Sorocaba City coming from the desconcentration of the industrial capital of São Paulo toward the country side of this same State. Due to this reality that happens since the decade of 1970 , the city of Sorocaba organized itself to receive these companies earmarking an area of the city that was called Industrial Zone with the function of placing them. In this zone, consisted by Éden, Cajurú do Sul and Aparecidinha, the following dissertation analysis the most recent transformations that happened in Éden neighborhood featuring some of the historical aspects, its relation with the public agents and with the industrial activities developed. The population everyday is considered as a relevant aspect to understand the changes occurred in the geographical space, not only of the neighborhood but of the municipality as well, which adds not only the pretensions, the local population wishes, and also the public and private agents, the closer partners to reach the capital reproduction in detriment of the social welfare.

Key words: industry, industrialization, Sorocaba, Éden, spatial organization 


\section{ÍNDICE}

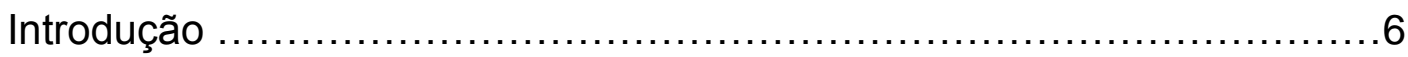

1- A dinâmica da indústria de Sorocaba e o processo de desconcentração

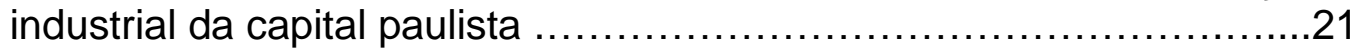

1.1- Indústria Sorocabana: a zona industrial ................................25

1.2- Os investimentos no setor industrial sorocabano ......................31

1.3- Investimentos: as atividades industriais em destaque.............. 37

2- O bairro do Éden e as indústrias ................................................. 40

2.1- Os problemas enfrentados pela população do bairro: uma breve análise..............................................................................

2.2- Uma nova perspectiva para a Zona Industrial..........................57

2.3- A divulgação de novos investimentos ...................................61

3- A luta pela emancipação ...................................................66

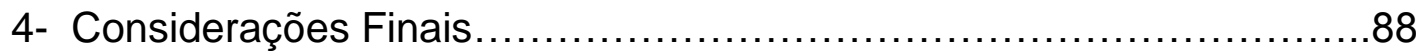

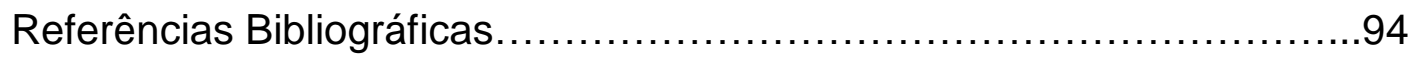




\section{INTRODUÇÃO}

A cidade de Sorocaba está localizada na região sudoeste do Estado de São Paulo, a 96 Km de distância da capital - São Paulo. A partir dos anos de 1970, com o processo de desconcentração industrial da cidade de São Paulo, recebeu diversas indústrias o que permitiu transformações na cidade. Desde os anos de 1960, com criação de uma comissão do Plano Diretor ${ }^{1}$ do Município (1961) e sua aprovação em 21 de novembro de $1966^{2}$, bem como alterações nos anos seguintes, houve a implantação de diversas indústrias interessadas em realizar seus negócios na chamada Manchester Paulista ${ }^{3}$.

Olhar para a cidade de Sorocaba atualmente e realizar comparação com que tínhamos há 40 anos atrás é sem dúvida notar grandes transformações espaciais que muito contribuíram para o crescimento econômico e social da cidade.

Estudar um lugar onde se vive e se percebe transformações em seu espaço, permite elaborar questionamentos sobre a cidade, sua história, sua indústria e a sua natureza, enfim sobre os motivos que proporcionaram as transformações. É bem verdade que a grande proximidade com o que se quer analisar exige cautela. É necessário ir além do superficial, realizando uma pesquisa que permita desvendar os processos que levaram e levam às mudanças na produção do espaço. Sendo assim, quando BAITZ (2006)

\footnotetext{
${ }^{1}$ LEI № 837, de 30 de Setembro de 1961

2 LEI № 1438, de 21 de novembro 1966

${ }^{3}$ Com a inauguração da Estrada de Ferro Sorocabana (EFS) em 1875 e a instalação de indústrias têxteis de origem inglesa, Sorocaba passou a ser conhecida como a Manchester Paulista - ( comparação com a cidade de Manchester na Inglaterra, devido ao desempenho das indústrias têxteis)

http://www.sorocaba.sp.gov.br/PortalGOV/do/conhecendoCidade?op=viewForm\&coConteudo=14002\&co SeqEstrutura=2242\&coEstruturaPai=12 - (acesso em 02/05/2008)
} 
escreve sobre o trabalho de campo, suas experiências, a implicação, o pesquisador, entre outros, uma frase chama atenção:

Implicação significa, primeiramente, que não se pode isolar certas peculiaridades da pesquisa em si mesmas; que o pesquisador faz parte da pesquisa (no campo, ele é mais um elemento do conjunto, portanto, mais um elemento a analisar) e que ele, consciente ou não, está imerso nessa relação e desempenha um mandato social muito especial (BAITZ, 2006, p.32).

Pensando no que foi revelado no texto de BAITZ, foi possível verificar que desenvolver uma pesquisa em um bairro da cidade de Sorocaba chamado Éden ${ }^{4}$, e fazer um paralelo com o que verificamos no bairro atualmente contendo áreas residencial e industrial, demonstra que há o crescimento da cidade e do bairro. Realizar um estudo dessa parte da cidade de Sorocaba ganha um significado especial pois, temos bibliografia sobre a indústria sorocabana como um todo, mas não especificamente da área para onde foram destinadas as indústrias da cidade, no caso o Éden e bairros vizinhos. Sendo assim, concentrar a análise numa relação entre bairro, cidade, estado e país vislumbrando as diversas escalas tornando a tarefa um compromisso social valoroso e expressivo que demandará comprometimento social.

O presente trabalho buscará estabelecer as relações que possam explicar o processo pelo qual ocorreram as transformações no bairro do Éden, associando à industrialização de Sorocaba e à desconcentração das indústrias da capital paulista desde a década de 1970, além de verificar quais foram as

\footnotetext{
${ }^{4}$ Éden - Bairro de Sorocaba. Inicialmente conhecido como vilarejo do Pirajibu do Meio, eram terras que pertenciam ao Estado e foram distribuídas às famílias de agricultores, através de intercessão do deputado estadual Cunha Bueno. Por esse motivo, o bairro homenageou a esposa do deputado, chamada Edna, com o nome Éden. Na década de 1960 o bairro do Éden foi escolhido para ser a futura zona industrial de Sorocaba, devido a apresentação de condições favoráveis a sua implantação. Devido a esse fato, o Éden recebeu muitos outros moradores, a maioria trabalhadores das indústrias, vindos de outras cidades. Assim o Éden teve sua origem terras que pertenciam ao Estado, composta por famílias de agricultores e anexadas ao município sorocabano a partir da Lei no 539 de 17 de dezembro de 1957. Fonte:http://www.sorocaba.com.br/enciclopedia/index.php?local=titulos\&tipo=verbetes\&ler $=1093318180$ (acesso em 02/05/2008)
} 
transformações que culminaram no crescimento do bairro e as possíveis tendências.

Sendo assim, a industrialização de Sorocaba, segundo SILVA (1995), tem sua gênese industrial datada na segunda metade do século XIX e nas primeiras décadas do século XX (1880 - 1930), possibilitou um dinamismo não apenas nas áreas centrais, mas expandindo-se a outras localidades da cidade gerando modificações nas funções que anteriormente existiam que no caso estudado passou de um bairro historicamente com características rurais para urbana.

A partir da necessidade em atender a instalação das indústrias que optam pela cidade como resultado do processo de desconcentração industrial no Estado de São Paulo, houve a criação de um Plano Diretor em meados da década de 1960, o qual teve sucessivas revisões, que orientava para uma organização espacial que atendesse esse processo de desconcentração industrial.

A questão que tentamos levantar é: como uma área que inicialmente foi constituída basicamente por famílias de agricultores, formada por poucas residências e uma infraestrutura considerada deficiente, conforme relato de moradores mais antigos do bairro, passou por melhorias atendendo as necessidades das indústrias e, ainda que marginalmente da população, a partir da instalação de indústrias no final dos anos de 1960, atualmente parece continuar a desfrutar de poucos investimentos públicos que melhorem o bem estar da população?

Podemos, por exemplo, citar a falta de investimentos em melhorias nas vias de acesso e circulação na Zona Industrial onde também temos o bairro do 
Éden, e na implementação de mais escolas públicas, pois as existentes já não são suficientes para atender a demanda da população local. Devemos lembrar que o bairro do Éden fica distante dos principais hospitais da cidade, aproximadamente $15 \mathrm{~km}$, conta apenas com uma unidade de Pronto Atendimento para uma população estimada em 40 mil pessoas entre Éden, Cajurú do Sul e Aparecidinha o que, segundo relatos de populares, apresenta deficiência no atendimento e na realização de determinados exames, sendo necessário se deslocarem a outras unidades pré-hospitalares para serem atendidos.

Embora a estrutura existente como fornecimento de água tratada, coleta de esgoto, energia elétrica, telefone, entre outras, esteja disponível para maior parte da população, não estamos desconsiderando ou negando a existência desses serviços e sim defendendo que outras benfeitorias poderiam ser realizadas, como ocorre em outros bairros, inclusive alguns mais recentes, que receberam investimentos, em sua melhoria no que diz respeito aos empreendimentos imobiliários, fato esse que será aprofundado posteriormente, mesmo não sendo o foco principal, mas fazendo parte do processo de transformação.

Ao observar um espaço e analisar as mudanças espaciais ocorridas pode-se perguntar: Quais são os elementos que influenciaram para que houvesse transformações nesse lugar?

Sabendo que as mudanças fazem parte do processo de constituição de um lugar, observar, analisar e aprofundar os estudos sobre a cidade de Sorocaba e especificamente a Zona Industrial no bairro do Éden, é de valor expressivo para mostrar a função que a cidade exerce, demonstrando que a 
cidade tem ganhos econômicos com a atividade industrial praticada. Em linhas gerais, ao analisar dados, imagens e informações é possível perceber as mudanças e a partir desses elementos verificar e analisar os processos espaciais que ocorreram e que muito deixam evidências que permitem uma melhor compreensão do local.

\section{Como CARLOS escreve:}

A nosso ver, o espaço geográfico deve ser concebido como um produto histórico e social das relações que se estabelecem entre sociedade e o meio circundante. Essas relações são, antes de mais nada, relações de trabalho dentro do processo produtivo geral da sociedade. Nesse contexto, o homem tem um papel central na medida que é sujeito, cuja humanidade é construída ao longo do processo histórico, concomitante à reprodução de sua própria vida (CARLOS, 2001, p.15).

Ao fazer a leitura do trecho citado podemos dizer que a ligação entre a indústria, bairro e cidade é parte de um processo da construção social que necessitou da atuação de um grupo de pessoas, pensando na gestão pública municipal, que mantinham interesses em organizar a cidade de forma que atraísse investimentos privados para compor a base econômica da cidade, sem, contudo, desconsiderar os interesses de outros agentes como, empresários, sociedade de amigos de bairros e associações de empreendedores. Há de termos a real consciência que os investimentos que se pretende atrair, além do industrial, também perpassam pelo comercial, o hoteleiro, o imobiliário, etc., objetivando o crescimento da cidade e dos negócios que nela possam acontecer. 
Segundo o último Plano Diretor ${ }^{5}$, revisado em 2007, estão presentes no bairro do Éden os seguintes zoneamentos: a Zona Industrial (ZI), a Zona Residencial (ZR3), a Zona de Chácaras Urbanas (ZCH) e a Zona de Conservação Ambiental (ZCA). O estabelecimento de alguns dos zoneamentos visa atender as necessidades de produção impulsionada pelo Estado e faz parte da lógica de transformação e crescimento econômico da cidade de Sorocaba.

Conforme a administração municipal divulgou em 2006, a cidade de Sorocaba cresce economicamente entre $3 \%$ e $4 \%$ ao ano, e o crescimento industrial é a atividade que mais tem contribuído para alavancar esses índices. Também faz parte desse processo de crescimento econômico o bairro do Éden localizado próximo à Rodovia Castelo Branco ${ }^{6}$, da Estrada Sorocaba-Itu (SP79), da Rodovia José Ermírio de Moraes (Castelinho) e Rodovia Raposo Tavares, interligadas pela Rodovia Celso Charuri. Sua localização estrategicamente favoreceu a instalação de indústrias, possibilitando a chegada de matéria-prima e o escoamento dos produtos da Zona Industrial. Portanto, potencializando a ampliação de negócios lucrativos para a cidade e absorvendo investimentos externos.

A ligação entre as vias de acesso citadas anteriormente que interligam a cidade tanto para a capital paulista quanto para o interior, explica na implantação da Zona Industrial nessa área estabelecida estrategicamente pelo Plano Diretor.

\footnotetext{
${ }^{5}$ LEI № 8.181, DE 05 DE JUNHO DE 2007. (Revisão da Lei 7.122 de 04/6/2004, que instituiu o novo Plano Diretor de Desenvolvimento Físico Territorial do Município de Sorocaba, e dá outras providências). ${ }^{6}$ A Rodovia Estadual Presidente Castelo Branco (SP-280), foi inaugurada em três etapas, tendo a primeira ocorrido em 10 de novembro de 1968, durante o governo Roberto de Abreu Sodré, trecho esse compreendido entre São Paulo e Torre de Pedra, num total de 171 quilômetros.
} 
Sobre a importância das vias de acesso que permitem a circulação de mercadorias para a instalação de um setor produtivo, Milton SANTOS afirma:

Com a difusão dos transportes e das comunicações cria-se a possibilidade da especialização produtiva. Regiões se especializaram, não mais precisando produzir tudo para sua subsistência, pois, com os meio rápidos e eficientes de transporte, podem buscar em qualquer outro ponto do país e mesmo do planeta, aquilo que se necessitam (SANTOS, 1991, p.50).

Já CARLOS explica que o processo de industrialização, ao provocar uma profunda alteração na divisão social e espacial do trabalho, implica mudanças radicais na vida do homem. A aglomeração da população, dos meios de produção e capitais num determinado ponto do espaço, multiplica os pontos de concentração e produz uma rede articulada e hierarquizada. E completa:

A indústria, por sua vez, para se desenvolver pressupõe a
concentração espacial beneficiando-se daquilo que os
economistas chamam de "economia de aglomeração":
infraestrutura, mão-de-obra, proximidade de outras indústrias
complementares, mercado diversificado e economia dos gastos de
produção. A indústria se aproveita, ao máximo, dessas vantagens
enquanto socializa as desvantagens (poluição,
congestionamentos, etc.) (CARLOS, 2001, p.35).

Levando-se em consideração o que citamos anteriormente, CARLOS (2001) escreve sobre a socialização das desvantagens e podemos fazer uma relação com os objetivos do Plano Diretor da cidade de Sorocaba, indicando que um de seus objetivos é o pleno desenvolvimento das funções sociais da cidade. Para tanto, chegamos a um questionamento se realmente haverá o desenvolvimento descrito ou simplesmente verificaremos as desvantagens socializadas a partir das transformações geradas pela industrialização da cidade que são identificadas facilmente por meio dos noticiários televisivos, do 
rádio, dos jornais entre outros meios de comunicação, tais como aumento da criminalidade, deficiência no atendimento médico, aumento do tráfego de veículos causando danos nas ruas e estradas, além dos acidentes.

É importante salientar que a cidade de Sorocaba só pode ser estudada na relação com outras escalas, seja diretamente ou indiretamente quando verificamos que existe uma variedade de indústrias de origem externa, oriundas de localidades tanto nacionais como internacionais. Também é prudente lembrar que as indústrias existentes em Sorocaba, e parte delas no Éden, atuam em diversos segmentos, como as de máquinas, autopeças, químicas, petroquímicas, farmacêuticas, entre outras. O atendimento a essa diversidade de segmentos necessita: mão-de-obra especializada, vias de acesso que permitam o escoamento da produção e o deslocamento de pessoas, sem esquecer de outros itens de infraestrutura como comunicação, transporte, universidades, etc., ampliando assim os requisitos que atendam os interesses de empresas de diversos setores, como por exemplo, as de informática, a química, a de telecomunicações e a farmacêutica.

Há de se considerar também que além da infraestrutura oferecida pela cidade, a proximidade com a capital do Estado de São Paulo, as cidades em seu entorno podendo oferecer mão-de-obra e áreas industriais a serem ocupadas por empresas interessadas em investir na cidade possibilitarão, segundo a prefeitura, o crescimento econômico e, porque não a nosso ver, algumas benfeitorias que a população possa desfrutar.

Como nos mostra CARLOS que:

O deslocamento de estabelecimentos industriais de São Paulo ganha sentido no bojo de um processo de mundialização que muda o perfil da economia a partir de profundas transformações 
no setor produtivo, em função da queda de taxas de lucros que exige uma diminuição dos custos de produção; neste setor cabem os custos com a modernização da fábrica, os custos com o terreno (seja com aluguel, IPTU), os impostos. Mas neste movimento dialético revela-se a integração de vários ramos da economia num outro patamar, bem como a desintegração de ramos tradicionais (CARLOS, 2004, p.54).

O deslocamento dos estabelecimentos industriais de São Paulo indicado por CARLOS, já nos anos de 1990, bem como a desconcentração industrial, esta atingindo um raio de $150 \mathrm{Km}$ da capital seguindo os principais eixos rodoviários a partir dos anos de 1970, conforme nos mostra LENCIONI (1994), são fenômenos que ajudam a entender as transformações na cidade de Sorocaba , exigindo das gestões públicas municipais desde os anos de 196070 , o planejamento e a organização da cidade de modo que pudesse receber novas indústrias e novos investimentos de outros setores.

Para que houvesse condições em receber novas indústrias, doação de terrenos e incentivos fiscais fizeram parte das medidas estratégicas para atrair empresas do ramo industrial, como exposto por CARLOS (2004), o que viabilizou o deslocamento de algumas indústrias da capital paulista em direção as cidades do interior do Estado, entre elas Sorocaba.

Com a instalação de um maior número de indústrias na cidade de Sorocaba e, consequentemente na Zona Industrial onde temos o bairro do Éden, atividades prestadoras de serviços como a bancária, supermercados, hotéis, restaurantes, entre outras, ganharam estímulos e empresários dessas atividades passaram a investir na cidade proporcionando assim o crescimento econômico sorocabano. 
No bairro do Éden, como exemplo, verificamos mudanças no trecho de aproximadamente de 6,5 Km da Avenida Independência ${ }^{7}$, acesso ao centro da cidade, as indústrias e as principais rodovias de escoamento da produção. Nesse trecho, nos últimos 20 anos surgiram mais intensamente atividades comerciais e bancárias e uma intensa circulação de veículos (foto 1).

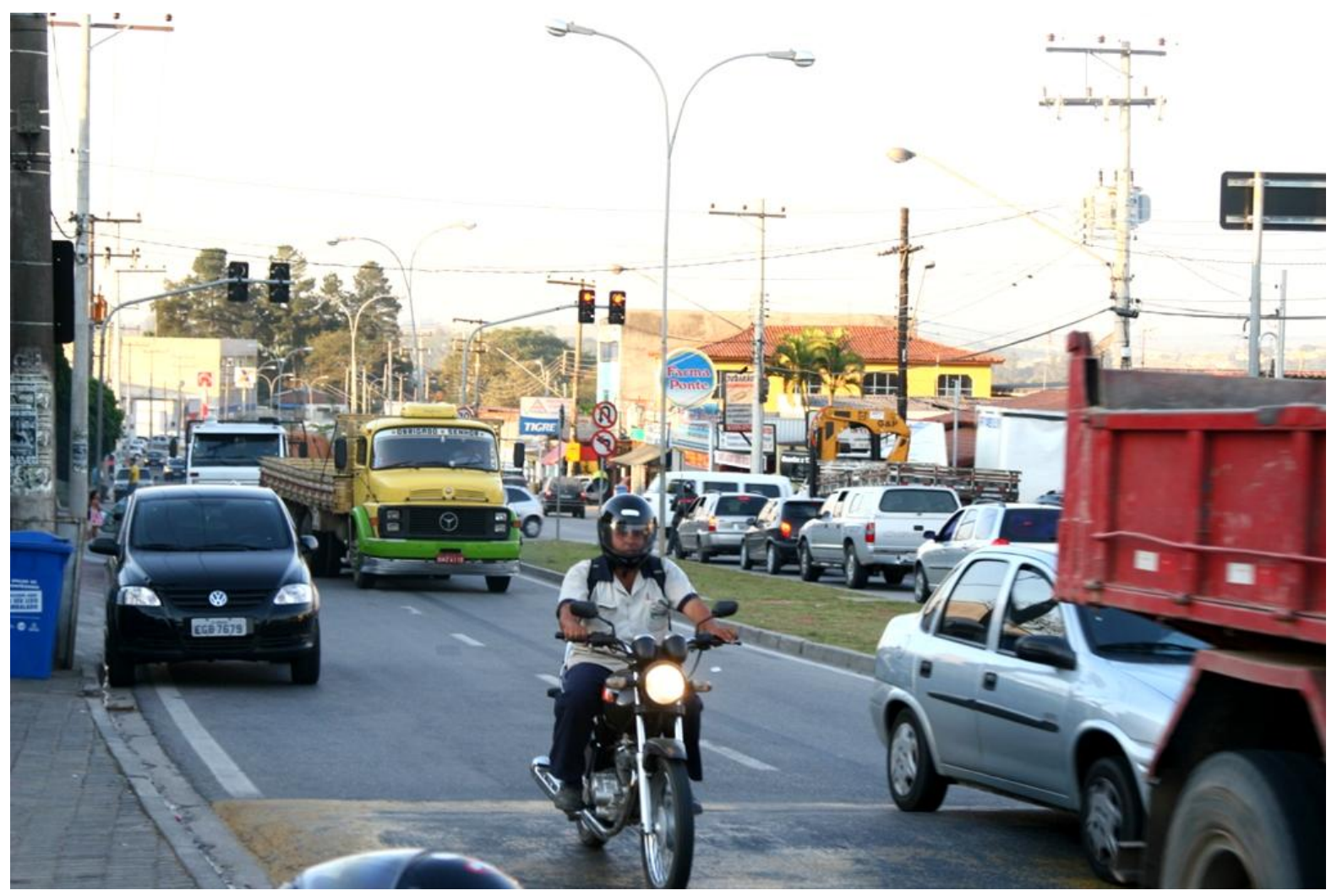

Foto1: Avenida Independência - Uma das principais vias do bairro e com elevado trânsito Autor: José Bernardo da Silva Data: 02/09/2009

Outro elemento presente na transformação do bairro é a presença de pequenas empresas na Zona Residencial 3 (ZR3) que conforme o Plano Diretor prevê no Art. $20^{8}$, itens I e II, a instalação de outras atividades que não

\footnotetext{
${ }^{7}$ Nos 6,5 km de extensão que passa pelo bairro, o trecho recebe o nome de Avenida Independência e faz parte da chamada Estrada Sorocaba-Itu (SP-79).

${ }^{8}$ Art.20 - Nas Zonas Residenciais 3 - ZR3, que compreende áreas localizadas junto aos principais vetores de expansão da cidade, destinadas predominantemente ao uso residencial, as normas de parcelamento, uso e ocupação do solo devem:

I- Admitir usos não residenciais, visando a proximidade entre habitação e locais de trabalho, desde que não causem incômodos para a população residente;
} 
sejam residenciais, surgindo assim diversos galpões de aluguel destinados tanto para fins comerciais quanto industriais.

O mesmo Plano Diretor, que traça diretrizes que regulamentam a atividade industrial e comercial, apresenta também a regulamentação para loteamento na cidade, o que tem promovido empreendimentos em condomínios fechados e loteamentos no bairro do Éden dinamizando o setor imobiliário.

Promover a manutenção e a ampliação da infraestrutura que a cidade de Sorocaba vem apresentando nas últimas três a quatro décadas, demonstra as fortes pretensões em atender as necessidades que possam permitir ligação com a capital, o estado e o país, alcançando escala mundial na realização de negócios potencializando o sistema econômico da cidade. Para isso SANTOS explica que:

Os espaços assim requalificados atendem sobretudo aos interesses dos atores hegemônicos da economia, da cultura e da política e são incorporados plenamente às novas correntes mundiais. O meio técnico-científico-informacional é a cara geográfica da globalização (SANTOS, 2001, p.239).

É prudente lembrar que a organização espacial da cidade de Sorocaba, bem como de outras cidades, por meio de suas infraestruturas atrai investimentos que passam por interesses tanto de investidores como da gestão pública, procurando seguir as tendências mundiais, adotando uma organização que especifica as áreas onde serão instaladas as indústrias, o comércio, as residências e adequando as estruturas já existentes.

Em Sorocaba, num determinado momento de sua história, foi propiciado nas estratégias do poder público, que um de seus bairros, o Éden, tivesse

II- Fixar índices urbanísticos compatíveis com edificações de padrão popular, inclusive prédios e apartamentos. 
significativas transformações adequando-o a uma Zona Industrial. Como consequência houve o crescimento da população do bairro passando nos anos de 1970 de 2.019 habitantes para 16.398 em 2000, conforme dados oficiais divulgados pelo IBGE e apresentado no gráfico 1.

Gráfico 1 - Crescimento da população do bairro do Éden (1970-200)

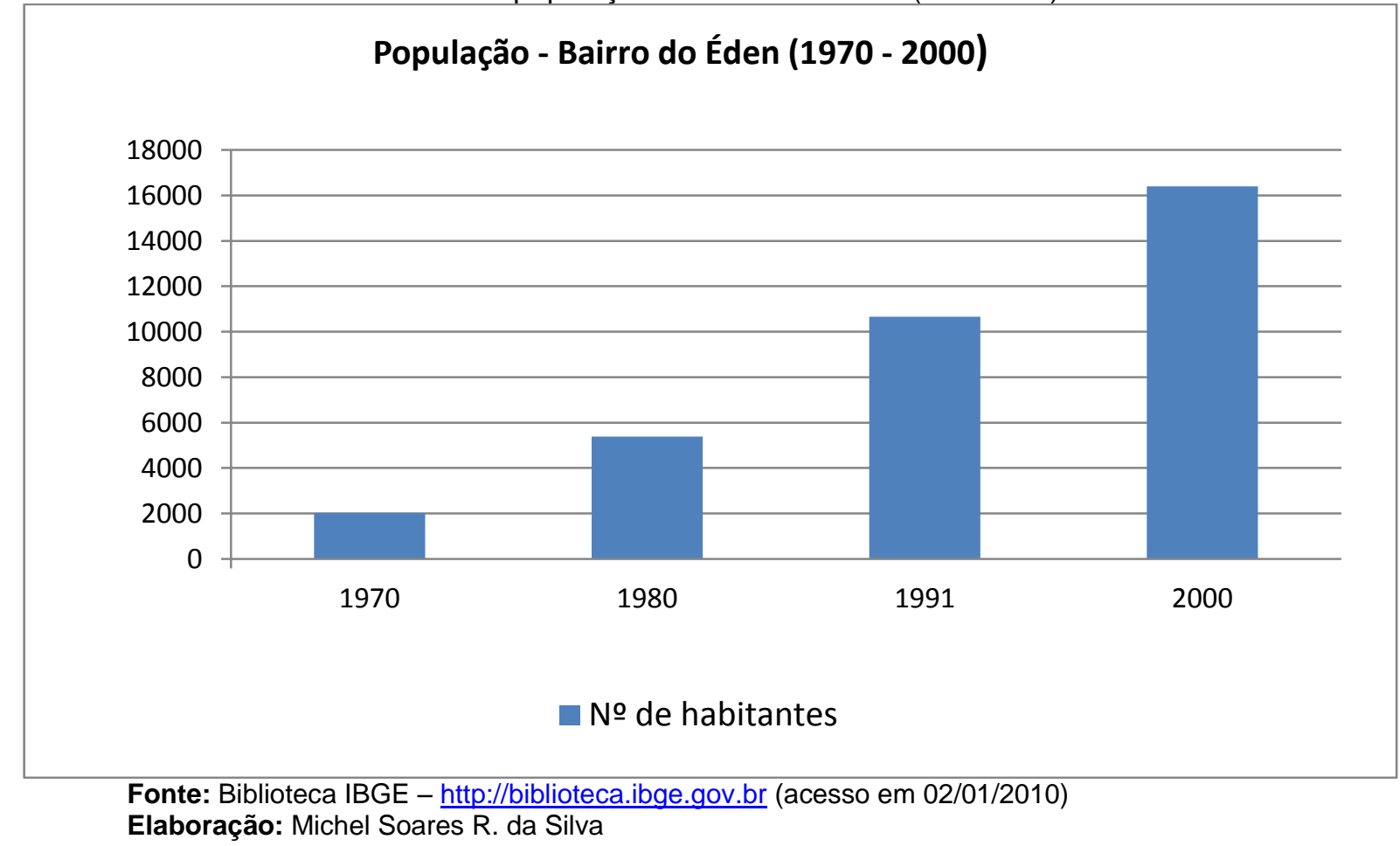

A título de comparação, o aumento da população de Sorocaba no mesmo período também apresenta crescimento conforme podemos verificar no gráfico 2, onde em 1970 a população de Sorocaba que era de 175.677 habitantes em trinta anos passa para 494.649 habitantes. 
Gráfico 2 - Crescimento da população de Sorocaba (1970-200)

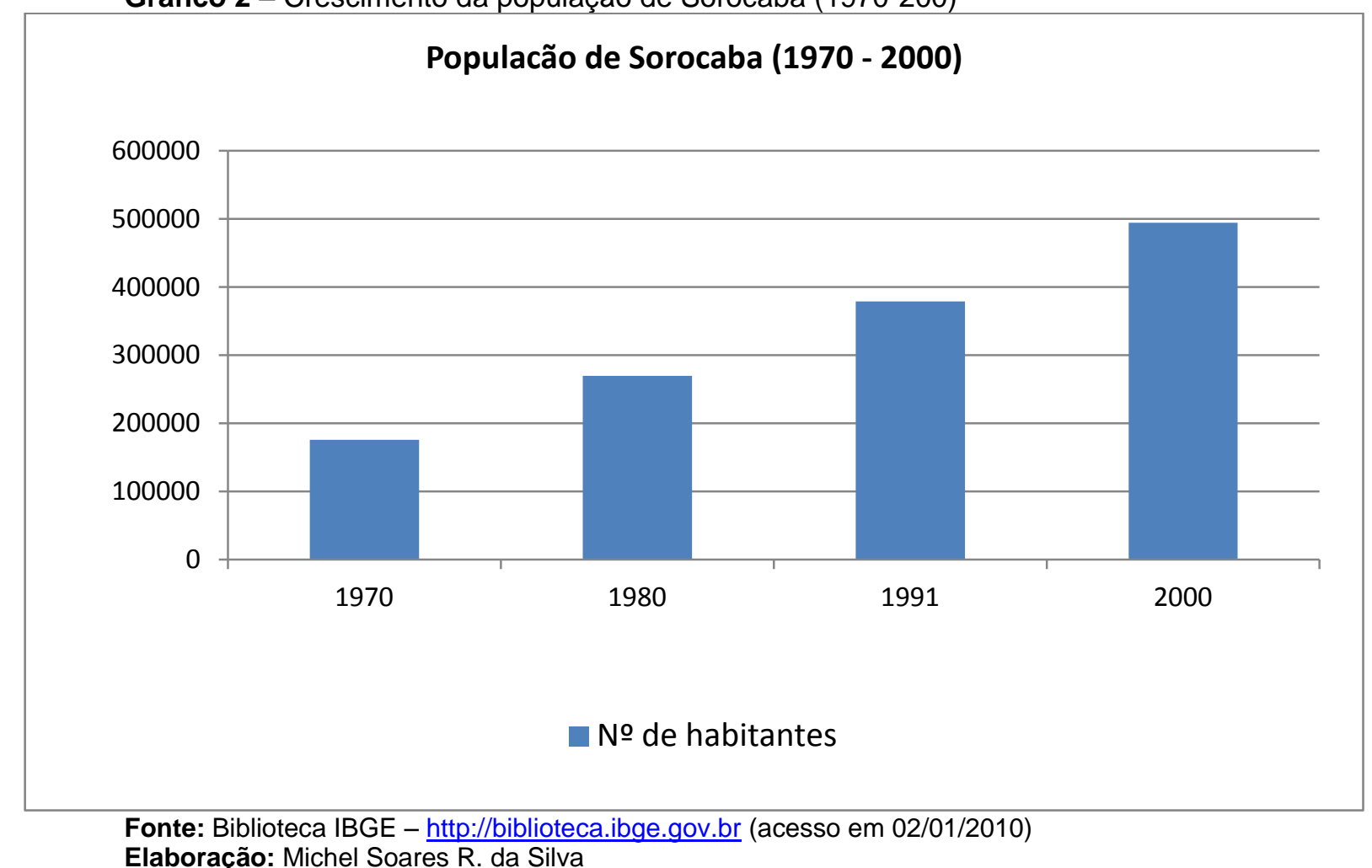

Elaboração: Michel Soares R. da Silva

Podemos atribuir esse aumento quantitativo da população às atividades industriais que passaram a ocorrer mais intensamente na cidade com os incentivos já citados, atraindo além de pessoas, como diz PEREIRA NETO9 (2005) que, conforme a diretoria regional do IBGE destaca, Sorocaba é um pólo migratório e de atração populacional, o que explica o elevado crescimento populacional.

Para melhor explanar o relato anterior realizamos um levantamento que nos mostra, segundo o censo de 1960 que dos 136.271 habitantes, 61.880 pessoas, representando $45,41 \%$ eram oriundos de outras localidades, sendo que 5459 estavam na cidade a menos de um ano. Já em 1970, dos 175.677

\footnotetext{
${ }^{9}$ Mario PEREIRA NETO. Sorocaba Globalizada. p.38
} 
habitantes, 78.474 deles eram provenientes de outros lugares e 6815 declararam residir na cidade a menos de um ano. Em 1980, dos 269.830 habitantes, 140.380 vieram de outras cidades/estados, um acréscimo de 55,9\% da população migrante. No ano de 1991, conforme dados coletados, Sorocaba contabilizava 379.006 habitantes, o número de migrantes eleva-se para 171.974 pessoas, representando, em relação ao censo anterior, um aumento 45,37\%, valor inferior entre os anos de 1970 e 1980, porém próximo ao apresentado em 1960.

Isso não significou que a cidade deixou de ser atrativa, mas o ritmo de crescimento da população migrante teve uma desaceleração, pois consideramos que o pico maior tenha sido justamente com a desconcentração industrial da capital em direção ao interior do Estado que coincide com o período de maior crescimento de migrantes em Sorocaba.

Para desenvolver essa dissertação, um dos primeiros passos foi discutir a dinâmica industrial sorocabana frente ao processo de desconcentração industrial da capital paulista em direção ao interior do Estado, que ocorreu a partir da década de 1970, demonstrando por meio de dados coletados do IBGE, da Fundação SEADE e da Prefeitura Municipal de Sorocaba, os encaminhamentos que ao longo dos últimos 40 anos possibilitaram 0 crescimento econômico do município, bem como os atrativos para investimentos, em especial o industrial.

Em seguida, procuramos concentrar a análise em uma área da cidade, a Zona Industrial, que durante o processo de industrialização recente do município exerceu a função de receber as indústrias que se deslocavam em direção ao interior paulista. Nessa área, analisamos o bairro do Éden expondo 
sua nova função no município a partir da introdução das indústrias, os problemas causados e a nova perspectiva por meio de novos investimentos.

Finalizamos com a análise dos motivos que promoveram a tentativa de emancipação do bairro do Éden e as futuras implicações para o bairro e para o município de Sorocaba. 


\section{1- A dinâmica da indústria de Sorocaba e o processo de desconcentração industrial da capital paulista}

Quando nos referimos à indústria de uma cidade, logo pensamos no histórico de sua industrialização, algo que proporciona um maior embasamento para tratar do assunto, pois por meio dos dados que são coletados durante o estudo, permite-nos verificar como se processou sua dinâmica, provocando alterações na infraestrutura, que no enfoque do nosso trabalho trata-se de Sorocaba.

Segundo dados do IBGE e da municipalidade, a cidade atualmente conta com cerca de $1836^{10}$ indústrias dos mais diversos segmentos produtivos (de transformação, 1820 e extrativas, 16), sendo algumas delas dos setores metalúrgico, químico, telecomunicações, entre outros.

Para melhor compreender os processos de mudanças que ocorrem em um determinado lugar, Carlos diz:

O desenvolvimento das forças produtivas produz mudanças constantes e com estas, a modificação do espaço urbano. Estas mudanças são hoje cada vez mais rápidas e profundas, gerando novas formas e configurações espaciais, novo ritmo de vida, novo relacionamento entre pessoas e novos valores. (CARLOS, 1992, p.27).

A partir da citação anterior, que nos fornece uma maior fundamentação sobre a dinâmica de uma cidade, e sabendo-se que a cidade de Sorocaba conta com uma numerosa quantidade de indústrias, podemos levar em consideração, pelo menos num primeiro momento, que isso permitiu a obtenção de investimento em outros segmentos da economia como o setor

\footnotetext{
${ }^{10}$ Dados extraídos dos Indicadores Sócio-Econômicos do Município de Sorocaba, divulgado em março 2009, através da Secretaria de Desenvolvimento Econômico e realizado pelo Pólo de Desenvolvimento e Inovação de Sorocaba (PODI) - Disponível no site:

http://www.sorocaba.sp.gov.br/PortalGOV/do/conhecendoCidade?op=viewForm\&coConteudo=32051\&co SeqEstrutura=2262\&coEstruturaPai=12 - (acesso em 12/10/2009)
} 
comercial, aparecendo grandes redes de hipermercados, setor hoteleiro, 0 bancário, lojas de departamentos, entretenimento, entre outros.

Compondo todos os setores econômicos citados anteriormente, a cidade obteve um PIB equivalente a $\mathrm{R} \$ 9.186 .220,00^{11}$ em 2005 (Tabela 1). Esse volume contribui para o Estado de São Paulo cerca de $1,26 \%$ do PIB, conferindo a cidade de Sorocaba, entre as 645 existentes, o $12^{\circ}$ lugar no ranking das cidade que mais contribuem com o Estado.

Tabela 1 - PIB (em milhões de reais) de algumas cidades do interior paulista e total do Estado de São Paulo

\begin{tabular}{|c|c|c|c|c|}
\hline \multirow[t]{2}{*}{ Municípios } & \multicolumn{4}{|c|}{ PIB (em milhões de reais) } \\
\hline & 2002 & 2003 & 2004 & 2005 \\
\hline ESTADO DE SÃO PAULO & $511.735,92$ & $579.846,92$ & $643.487,49$ & $727.052,82$ \\
\hline Americana & $3.101,71$ & $3.584,67$ & $4.186,97$ & $4.318,74$ \\
\hline Bauru & $2.944,69$ & $3.187,25$ & $3.550,49$ & $4.092,18$ \\
\hline Campinas & $14.774,74$ & $15.382,74$ & $17.453,58$ & $20.620,77$ \\
\hline Indaiatuba & $1.656,11$ & $2.462,61$ & $3.176,15$ & $3.414,34$ \\
\hline Itu & $1.584,01$ & $1.981,76$ & $2.393,90$ & $2.742,82$ \\
\hline Jundiaí & $6.527,18$ & $7.586,17$ & $9.567,54$ & $10.185,10$ \\
\hline Limeira & $2.934,75$ & $3.505,39$ & $3.834,02$ & $4.171,21$ \\
\hline Piracicaba & $4.190,54$ & $4.674,45$ & $5.294,68$ & $5.761,76$ \\
\hline S.J.Campos & $14.216,80$ & $13.782,07$ & $17.428,15$ & $17.090,19$ \\
\hline Sorocaba & $5.889,02$ & $6.922,16$ & $8.013,90$ & $9.186,22$ \\
\hline Taubaté & $3.906,33$ & $4.095,33$ & $4.458,09$ & $4.618,51$ \\
\hline
\end{tabular}

Fonte: Fundação Seade; Instituto de Geografia e Estatística - IBGE

Elaboração: Michel Soares R. da Silva

11 Valor de US\$3,925,064.00 - (R\$2,3407 - cotação de 30/12/2005) - Fonte: Banco Central do Brasil 
Há de se considerar que ao apreciarmos tal volume do PIB, o setor industrial tem sua parcela de contribuição no Valor Adicionado, chegando a $R \$$ 2.661.340,00 em 2005, 1,37\% do PIB total do Estado e 28,97\% do município conforme dados extraídos da Fundação Seade; Instituto de Geografia e Estatística - IBGE.

O gráfico 1 a seguir demonstra a evolução do PIB de algumas cidades do Estado de São Paulo entre 2002-2005 e Sorocaba apresenta crescimento em todos os anos.

Gráfico 1 - PIB (em milhões de reais) de algumas cidades do Estado de São Paulo

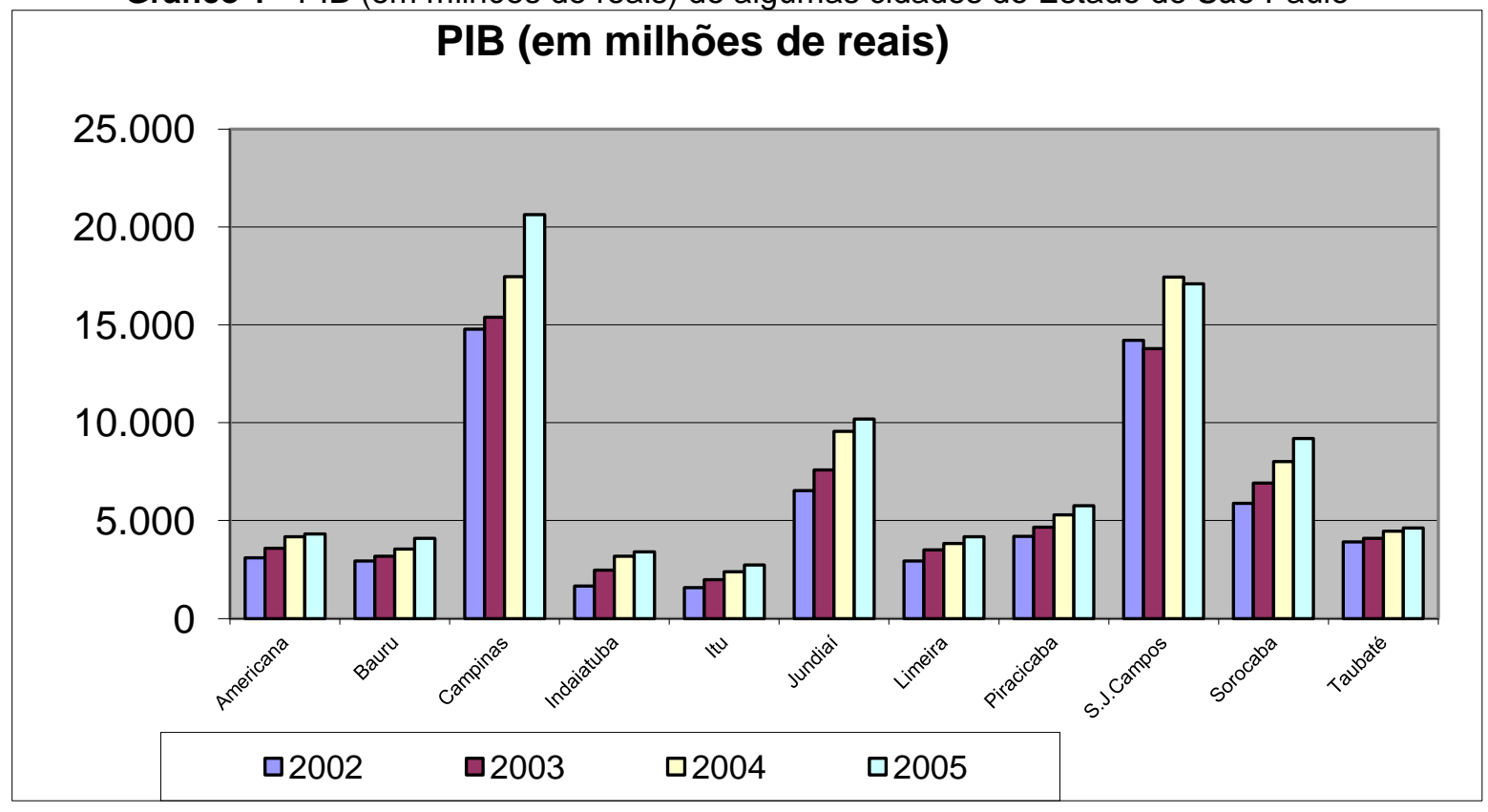

Fonte: Fundação Seade; Instituto de Geografia e Estatística - IBGE

Elaboração: Michel Soares R. da Silva

Provavelmente, o que tenha contribuído para que houvesse essa participação de geração de riqueza para o Estado foi o processo de desconcentração industrial iniciada nos anos de 1970, transferindo seletivamente uma parcela das indústrias da capital paulista e da Região Metropolitana de São Paulo (RMSP), para cidades do interior paulista numa distância aproximada de 150 Km, conforme Lencioni (1994) mostra em seus 
estudos sobre o processo de desconcentração industrial no Estado de São Paulo, estudo este de inestimável valor para a compreensão desse processo, bem como a lógica de reprodução do capital. Para tanto, diz Lencioni :

A política de descentralização industrial significou, sobretudo, dispersão abrangendo um raio de cerca de $150 \mathrm{Km}$ a partir da capital e, indo além desta distância, ao longo dos principais eixos rodoviários. A presente dispersão não nega os processos históricos de concentração industrial no território paulista, mas reforça a expansão da metrópole como condição e elemento deste processo (1994, p.56).

Durante esse processo a cidade de Sorocaba, contando com um passado histórico industrial, tendo seus limites próximos das Rodovias Presidente Castelo Branco e Raposo Tavares que oferecem acesso para o interior do Estado, possuía elementos que contribuíram para as empresas se deslocarem da capital para a cidade. Podemos notar também que, mesmo havendo o processo de desconcentração industrial, o vínculo com a capital ainda se faz presente, como diz Lencioni:

Muito da dispersão industrial está vinculado a processos de centralização do capital, pois enquanto estreitam-se as possibilidades de investimentos das pequenas e médias empresas, se ampliam, ainda mais, as vantagens dos grandes monopólios capazes de procederem ao controle dos capitais (1994, p.58).

Nota-se, portanto, que o vínculo existente entre o processo de desconcentração industrial, as cidades, em nosso caso Sorocaba, e o processo de centralização do capital, tem uma função reguladora que determina o destino dos investimentos para que o processo de reprodução do capital seja realizado com a maior rentabilidade possível. Diante dessa ação reguladora que centraliza o capital organiza-se todo o processo produtivo e um sistema econômico que hierarquiza cidades dentro do país e no mundo. 
Em nosso caso particular que trata da industrialização da cidade de Sorocaba, o bairro do Éden, local onde concentra algumas das indústrias de Sorocaba, constituiu-se como parte integrante da desconcentração industrial da capital ao receber tal atividade econômica, bem como se subordinando aos processos de centralização do capital cumprindo sua função para a reprodução do capital.

A seguir tentaremos descrever a relação entre 0 processo de industrialização de Sorocaba e o bairro do Éden, parte integrante da Zona Industrial que durante anos, com a instalação das indústrias, promovem transformações constantes.

\section{1- Indústria Sorocabana: a zona industrial}

Colocamos anteriormente um panorama geral vinculando a desconcentração industrial a partir dos anos de 1970, com relação ao processo de industrialização de Sorocaba pretendemos discutir a indústria sorocabana, analisando como esse setor contribui com a geração de riqueza econômica para a cidade.

Conforme foi sinalizado anteriormente, existe uma grande diversidade industrial em Sorocaba como mostra a tabela 2. 
Tabela 2 - TIPOS DE INDÚSTRIAS EM SOROCABA

\begin{tabular}{|c|c|}
\hline TIPO DE INDÚSTRIA & QUANTIDADE \\
\hline INDÚSTRIA DE ARTEFATOS DE FERRO E METAL & 309 \\
\hline INDÚSTRIA DE PECAS, ACESSÓRIOS E SIMILARES & 185 \\
\hline INDÚSTRIA DE VESTIMENTA & 148 \\
\hline INDÚSTRIA DE PRODUTOS ALIMENTÍCIOS & 116 \\
\hline INDÚSTRIA DE TRATORES, MÁQUINAS E SIMILARES & 92 \\
\hline INDÚSTRIA METALÚRGICA & 88 \\
\hline INDÚSTRIA ARTEFATO PLÁSTICO E BORRACHA & 82 \\
\hline INDÚSTRIA DE PRODUTOS NAO METÁLICOS & 73 \\
\hline INDÚSTRIA DE ARTIGOS DE TECIDO & 69 \\
\hline INDÚSTRIA DE MOBILIARIO & 46 \\
\hline INDÚSTRIA QUÍMICA E FARMACÊUTICA & 41 \\
\hline INDÚSTRIA TECELAGEM & 25 \\
\hline INDÚSTRIA DE MADEIRA E CORTIÇA & 24 \\
\hline INDÚSTRIA TEXTIL & 17 \\
\hline INDÚSTRIA DE PAPEL E PAPELÃO & 15 \\
\hline INDÚSTRIA DE COURO, PELE E SIMILARES & 13 \\
\hline INDÚSTRIA MECÂNICA E ELÉTRICA & 11 \\
\hline INDÚSTRIA DE BEBIDAS & 8 \\
\hline INDÚSTRIA EXTRATIVA MINERAL & 7 \\
\hline INDÚSTRIA FIAÇÃO & 3 \\
\hline INDÚSTRIA CALÇADO & 2 \\
\hline INDÚSTRIA EXTRATIVA VEGETAL & 1 \\
\hline OUTRAS INDÚSTRIAS & 27 \\
\hline
\end{tabular}

Fonte: Prefeitura Municipal de Sorocaba- Secretaria de Desenvolvimento Econômico - Data: 12/01/2010 - (acesso em 19/01/2010)

Elaboração: Michel Soares R. da Silva 
De acordo com a tabela acima, verificamos uma variedade nos tipos de indústrias em Sorocaba o que indica que o setor produtivo contribui para o crescimento econômico da cidade gerando no ano de 2007, conforme tabela 3, um valor adicionado industrial de $R \$ 3.486 .140,00^{12}$ e participação no PIB de $1,55 \%$ ocupando a $9^{a}$ posição entre as cidades que mais contribuíram para o Estado considerando o setor industrial, expressando valores superiores ao ano de 2005 apresentados na tabela 1, indicando assim, uma tendência de crescimento econômico nesse setor.

Tabela 3 - Valor Adicionado da Indústria (1) e Participação no Total Municípios Selecionados do Estado de São Paulo (2) - 2007

\begin{tabular}{|l|c|c|c|}
\hline \multicolumn{1}{|c|}{ Municípios } & VA Industrial (em & Participação (\%) & Participação \\
& $\begin{array}{c}\text { R milhões } \\
\text { correntes) }\end{array}$ & & Acumulada (\%) \\
& $\mathbf{2 2 5 . 1 2 5 , 0 5}$ & $\mathbf{1 0 0 , 0 0}$ & $\mathbf{1 0 0 , 0 0}$ \\
\hline Total do Estado & $59.080,71$ & 26,24 & 26,24 \\
\hline 1. São Paulo & $9.019,97$ & 4,01 & 30,25 \\
\hline 2. São Bernardo do Campo & $7.969,24$ & 3,54 & 37,06 \\
\hline 3. São José dos Campos & $7.357,33$ & 3,27 & 39,42 \\
\hline 4. Guarulhos & $5.328,06$ & 2,37 & 41,42 \\
\hline 5. Campinas & $4.488,70$ & 1,99 & 43,28 \\
\hline 6. Santo André & $4.188,10$ & 1,86 & 46,01 \\
\hline 7. Jundiaí & $3.893,91$ & 1,73 & $\mathbf{4 6 , 5 6}$ \\
\hline 8. Barueri & $\mathbf{3 . 4 8 6 , 1 4}$ & $\mathbf{1 , 5 5}$ & \\
\hline 9. Sorocaba & $3.350,55$ & 1,49 & \\
\hline 10. Diadema & & & \\
\hline
\end{tabular}

Fonte: Fundação Seade; IBGE.

(1) A preços correntes.

(2) Correspondem aos dez municípios com maior VA da Indústria.

\footnotetext{
${ }^{12}$ Valor de US\$1,968,125.10 - (R\$1,77130 - cotação de 31/12/2007) - Fonte: Banco Central do Brasil
} 
Sorocaba, ao demonstrar diversidade no setor industrial e crescimento econômico no valor industrial de $\mathrm{R} \$ 1.562,44$ em 2002, ampliando esses números para $\mathrm{R} \$ 3.486,14$ em 2007 , crescimento de $123,12 \%$ nesse período, a gestão pública municipal oficializa por meio da LEI № 8599, de 16 de outubro de 2008, a criação do Parque Tecnológico de Sorocaba previsto no Plano Diretor, com intenções em ampliar a capacidade da cidade em atrair negócios ligados ao setor industrial e outros setores que contribuem para o crescimento econômico. Como parte da estratégia para atrair investimentos para a cidade, em 2009 foi divulgado o Termo de Referência do Parque Tecnológico Incentivado de Sorocaba, contendo um conjunto de informações referentes às características da cidade, do local de instalação do Parque Tecnológico, da infraestrutura que será oferecida, dos incentivos fiscais, entre outros dados.

Outro item a ser acrescentado é a quantidade de empregados na indústria de Sorocaba que, segundo a Fundação SEADE (tabela 4), chegou a 57.071 de pessoas ocupadas no setor industrial.

Tabela 4 - Número de estabelecimentos industriais e empregos ocupados nas indústrias de Sorocaba - (2008)

\begin{tabular}{|c|l|c|}
\hline \multicolumn{1}{|c|}{ Localidade } & \multicolumn{1}{|c|}{ Variável } & Total da Indústria \\
\hline \multirow{2}{*}{ Sorocaba } & \begin{tabular}{l} 
Número de estabelecimentos da indústria \\
\cline { 2 - 3 }
\end{tabular} & $\begin{array}{l}\text { Empregos ocupados na indústria (vínculos } \\
\text { no ano) }\end{array}$ \\
\hline
\end{tabular}

Fonte: Fundação SEADE - 2008 (acesso em 06/03/2011)

Elaboração: Michel Soares R. da Silva

Essa significativa participação de empregos ocupados no setor industrial apresentado na tabela acima, no ano de 2008 representou 35,92\% na 
participação dos vínculos empregatícios nas indústrias de Sorocaba no total geral do Estado de São Paulo, conforme gráfico 2 abaixo.

Gráfico 2 - Vínculos empregatícios na Indústria - 2008

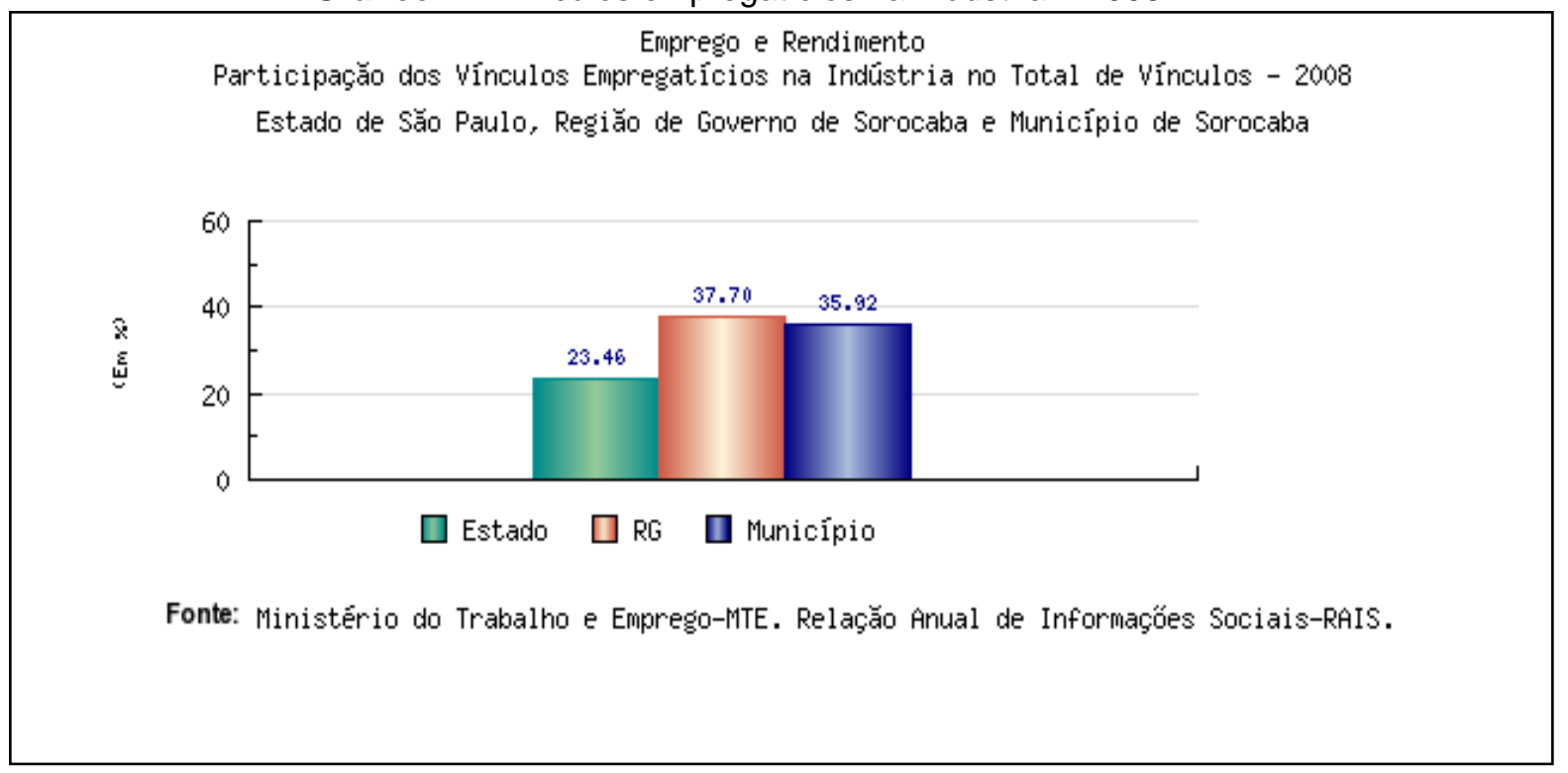

Como a cidade de Sorocaba a partir de 1965, deixou de contabilizar em seus cofres a produção de riqueza do então Distrito de Votorantim ${ }^{13}$, a desestabilização do sistema econômico sorocabano causa grande preocupação e os agentes locais buscaram alternativas para enfrentar essa nova e desafiadora condição econômica.

Para solucionar o problema de arrecadação de impostos em Sorocaba que se avistava, já que a emancipação de Votorantim seria inevitável, paralelamente ao processo de emancipação (que se inicia em 1962) criou-se uma comissão para elaborar um Plano Piloto de Desenvolvimento do Município que foi aprovada em 1963 estabelecendo três tipos de zonas distintas, sendo a zona residencial, a comercial e a industrial, com grande interesse da prefeitura

\footnotetext{
13 Com a emancipação do Distrito de Votorantim em 27/03/1965, a cidade de Sorocaba deixa de arrecadar os impostos das indústrias nele instaladas, como a do Grupo Votorantim e a Fábrica de Tecidos Metidiéri.
} 
em organizar e atrair indústrias a migrarem para a cidade e assim, reequilibrar e ampliar sua economia, pois era fundamental para o crescimento da cidade.

Tendo em vista os problemas ocasionados com a emancipação de Votorantim, o Plano Piloto foi sendo adequado para atender as necessidades na implantação de uma Zona Industrial conforme as recomendações de um corpo técnico envolvido em sua elaboração, estabelecendo assim uma nova organização espacial na cidade e em 1966 o plano é aprovado contendo novas diretrizes afastando a Zona Industrial das áreas próximas do centro da cidade, diferente do plano anterior, utilizando como referência as principais vias de acesso rodoviário como pontos importantes para a instalação das indústrias.

A partir do processo de organização territorial da cidade para estabelecer a Zona Industrial de Sorocaba, o bairro do Éden, parte integrante desse processo, passou e passa por transformações inerentes ao processo de urbanização. Sobre o processo de urbanização, Lefebvre aponta que:

Desestruturações e reestruturações se sucedem no tempo e no espaço, sempre traduzidas para a prática, inscritas no práticosensível, escritas no texto urbano, mas provenientes de outro lugar: da história, do devenir (LEFEBVRE, 2001, p.60).

Podemos perceber que todo o processo pelo qual Sorocaba com seus bairros passou e passa está vinculado a outros lugares do mundo que interferem diretamente ou indiretamente nas ações municipais, assim como acontece nas escalas nacional e estadual que determinam e promovem transformações que atendam ao ciclo do capital criando e organizando um espaço que articule ações práticas entre a produção e a sociedade numa incessante busca pelo lucro. 
Para tratarmos das transformações que ao longo da história aconteceram no bairro do Éden, levantaremos as relações existentes entre os diversos agentes produtores da vida no bairro, assim como na cidade, todos estão diretamente envolvidos na implantação das indústrias na área, demonstrando alguns pontos que achamos relevantes e que posteriormente podem ser debatidos com maior profundidade.

\section{2- Os investimentos no setor industrial sorocabano}

A cidade de Sorocaba, com seu histórico de desenvolvimento industrial, pautado inicialmente na industrial têxtil já no final do século XIX (1870), sofre mudanças socioespaciais a partir de ações planejadas pelo poder público, de modo a implementar as estruturas necessárias que permitiram receber o setor industrial e, graças aos incentivos de leis municipais, propiciaram condições para atrair investimentos tanto no setor industrial como em outros setores. Isso contribuiu para o seu crescimento econômico e, pelo que foi constatado, durante anos a cidade de Sorocaba foi, no Estado de São Paulo, uma das que mais recebeu investimentos expressivos do setor privado na instalação industrial, destinados na implantação, ampliação, modernização e timidamente pesquisa e desenvolvimento.

Com relação aos investimentos realizados na cidade no período, entre o ano de 1998 e o primeiro semestre de 2009, segundo levantamento realizado pelo SEADE, dos investimentos ${ }^{14}$ informados, pudemos constatar que estes

14 1- Pesquisa realizada a partir de anúncios publicados na Gazeta Mercantil, Folha de S.Paulo, O Estado de S.Paulo, DCl e outros. 2- Os dados de janeiro a junho de 2009 são preliminares. 
totalizaram um valor de US\$2,06 bilhões de dólares, conforme indicado na tabela 5 abaixo.

Tabela 5 - Investimentos anunciados para Sorocaba (de 1998 a 1은 Semestre 2009)

\begin{tabular}{cc}
\hline SETOR & Valor (em US\$ Milhões) \\
\hline Indústria & 1598,53 \\
Comércio & 95,02 \\
Serviços & 373,16 \\
TOTAL & 2066,71 \\
\hline $\begin{array}{l}\text { Fonte: Fundação Seade; Pesquisa de Investimentos de SP - PIESP. (Jan/2010) } \\
\text { Elaboração: Michel Soares R. da Silva (acesso em 06/02/2010 - atualização) }\end{array}$
\end{tabular}

Desse total de investimentos, US\$1,59 bilhão de dólares, ou seja $77,3 \%$, foram destinados ao setor industrial mostrando a importância deste tipo de investimento na cidade de Sorocaba.

Os dados organizados e divulgados pelo SEADE mostram a origem do capital investido no setor industrial: além do capital nacional cujos investimentos foram de US\$238,08 milhões de dólares, também houve capital externo proveniente da Alemanha, Canadá, Dinamarca, Espanha, Estados Unidos, Finlândia, Itália, Inglaterra, Japão e Suécia, conforme demonstra a tabela 6 . Entre os países que aparecem como os maiores investidores estão a Itália, com investimentos de US\$ 636,47 milhões, em que desse total US\$ 565,13 milhões são destinados na implantação da Case/Grupo Fiat ${ }^{15}$; os EUA com investimentos na ordem de US $\$ 371,74$ e a Alemanha com US $\$ 156,89$.

\footnotetext{
${ }^{15}$ Anunciado no ano de 2007 e período previsto do investimento entre os anos de 2007 e 2010. A inauguração ocorreu no dia 02/03/2010 com a presença do Prefeito, do governador do Estado de São Paulo e do Presidente da República.
} 
Tabela 6 - Países investidores no setor industrial (1998 - 1은 Semestre 2009)

\begin{tabular}{|l|c|}
\hline \multicolumn{1}{|c|}{ Países Investidores } & $\begin{array}{c}\text { Valor } \\
\text { (em US\$ Milhões) }\end{array}$ \\
\hline Alemanha & 156,89 \\
\hline Brasil & 238,08 \\
\hline Canadá & 0,43 \\
\hline Dinamarca & 3,94 \\
\hline Espanha & 80,07 \\
\hline EUA & 371,74 \\
\hline Finlândia & 15,93 \\
\hline Inglaterra & 16,5 \\
\hline Itália & 636,47 \\
\hline Japão & 1598,53 \\
\hline Suécia & 14,35 \\
\hline Misto (Brasil/Holanda) & 22,12 \\
\hline TOTAL & \\
\hline
\end{tabular}

Fonte: Fundação Seade; Pesquisa de Investimentos de SP - PIESP. (Jan/2010) Elaboração: Michel Soares R. da Silva (acesso em 06/02/2010 - atualização)

Como podemos observar na tabela 5 , o setor comercial e de serviços apresentam valores investidos inferiores ao do setor industrial e a origem do capital investido, embora em maior parte seja brasileiro, há investimentos da França, dos Estados Unidos, da Holanda, entre outros, conforme apresentado na tabela a seguir. 
Tabela 7 - Países investidores no setor comercial e de serviços (1998 - 1은 Semestre 2009)

\begin{tabular}{|c|c|}
\hline $\begin{array}{c}\text { Países Investidores } \\
\text { (COMÉRCIO) }\end{array}$ & $\begin{array}{c}\text { Valor } \\
\text { (em US\$ Milhões) }\end{array}$ \\
\hline Brasil & 50,07 \\
\hline Dinamarca & 0,09 \\
\hline EUA & 5,47 \\
\hline França & 16,74 \\
\hline Holanda & 2,4 \\
\hline Inglaterra & 0,8 \\
\hline Misto (Brasil/França) & 19,45 \\
\hline TOTAL & 95,02 \\
\hline $\begin{array}{c}\text { Países Investidores } \\
\text { (SERVIÇOS) }\end{array}$ & $\begin{array}{c}\text { Valor } \\
\text { (em US\$ Milhões) }\end{array}$ \\
\hline Brasil & 366,27 \\
\hline Canadá & 0,22 \\
\hline EUA & 2,87 \\
\hline França & 3,8 \\
\hline TOTAL & 373,16 \\
\hline
\end{tabular}

Fonte: Fundação Seade; Pesquisa de Investimentos de SP - PIESP. (Jan/2010) Elaboração: Michel Soares R. da Silva (acesso em 06/02/2010 - atualização)

Fazendo uma análise da tabela 7 , ficou nítido que os investimentos tiveram um direcionamento específico para o setor de serviços, com maior volume de capital brasileiro, cerca de US\$366,27 milhões. Desse modo, como exemplo dos investimentos realizados na cidade de Sorocaba no setor de 
serviços, podemos citar a ampliação da ALL - América Latina Logística (US\$ 27,53 milhões) e da Estação Aduaneira do Interior/ Grupo Aurora (US\$ 21,93 milhões), às margens da Rodovia José Ermírio de Moraes (Castelinho) e na Zona Industrial de Sorocaba. Como um exemplo de tipo de investimento no comércio, temos a implantação do Villaggio Shopping (US\$ 26,62 milhões) inaugurado em 26 de novembro de 2010.

Os investimentos no setor comercial são mais modestos e podemos citar como exemplo mais significativo a implantação de unidades do Grupo Pão de Açúcar/ Extra, valor de US\$19,15 milhões anunciado em 2000 e para o mesmo grupo em 2008 no valor de US\$19,45 milhões.

Relacionamos alguns dos investimentos que tiveram os maiores valores embora existam outros que, assim como os anteriormente citados, em nossa análise demonstram interesse de investidores em diversos setores da economia, porém, a tendência dos maiores investimentos concentra-se no setor industrial, passando para o setor de serviços e chegando ao setor comercial, revelando uma hierarquia nos interesses dos investidores nos setores da economia sorocabana.

A pesquisa do SEADE também divulga os tipos de investimentos (tabela 8) que foram realizados caracterizando-os em, além de implantação, também os referentes a ampliação, modernização e pesquisa e desenvolvimento. Ao analisar os dados observamos que os tipos de investimento, em sua maioria, são destinados à ampliação e modernização do setor industrial. Já os investimentos em pesquisa e desenvolvimento apresentados aparecem apenas em algumas atividades da indústria como o de eletricidade, gás e água quente, produtos farmacêuticos, máquinas e equipamentos e papel e celulose. Sendo 
assim, percebemos que se trata de investimentos que convergem, em sua maior parte, para a produção de mercadorias, enquanto o setor comercial e de serviços recebe um volume menor de investimentos.

Tabela 8: Tipos de investimentos por atividade econômica (em milhões de US\$) (de 1998 a $1^{\circ}$ Semestre 2009)

Tipo de Investimento Indústria Comércio Serviços

\begin{tabular}{|c|c|c|c|c|}
\hline Ampliação & 456,96 & 2,76 & 184,63 & \\
\hline Implantação & 970,67 & 90,2 & 173,96 & \\
\hline Modernização & 165,05 & 2,06 & 14,57 & \\
\hline Pesq. \& Desenv. & 5,85 & 0 & 0 & \\
\hline TOTAL & 1598,53 & 95,02 & 373,16 & \\
\hline TOTAL GERAL & & & & 2066,71 \\
\hline
\end{tabular}

Fonte: Fundação Seade; Pesquisa de Investimentos de SP - PIESP. (Jan/2010)

Elaboração: Michel Soares R. da Silva (acesso em 06/02/2010 - atualização)

Os dados mostram que o investimento em pesquisa e desenvolvimento no setor industrial, cerca de US \$ 5,85 milhões, demonstra-se ínfimo em relação aos outros investimentos anteriormente mencionados.

Como os investimentos anunciados estão concentrados no setor industrial e com valores destinados especialmente em implantação e ampliação, acreditamos ser importante analisar os dados para verificar em quais atividades industriais especificamente estão sendo aplicados Sendo assim, trataremos dessa análise em um novo item reunindo as informações necessárias. 


\section{3- Investimentos: as atividades industriais em destaque}

Como em nosso estudo estamos observando os impactos promovidos pelo setor industrial, elaboramos a tabela $9 \mathrm{com}$ as atividades em maior evidência para termos uma noção de como as articulações com outros setores da economia se processam.

Tabela 9: Investimentos por Atividade industrial (Valores em US\$ milhões)

\begin{tabular}{|c|c|c|c|c|c|c|c|c|c|c|}
\hline CLAS & ATIVIDADE & AMPLIAÇÃO & $(\%)$ & IMPLANTAÇÃO & $(\%)$ & MODERNIZAÇÃO & $(\%)$ & PESQ. E DESENV. & $(\%)$ & INVEST./ATIV \\
\hline 1 & Máquinas e Equipamentos & 19,33 & 4,23 & 574,88 & 59,2 & 8,67 & 5,25 & 0,91 & 15,6 & 603,79 \\
\hline 2 & Automotiva & 162,13 & 35,5 & 51,83 & 5,34 & 79,44 & 48,1 & & 0 & 293,4 \\
\hline 3 & Material Eletrônico e Equip. Comunicação & 4,7 & 1,03 & 97,63 & 10,1 & 60 & 36,4 & & 0 & 162,33 \\
\hline 4 & Captação, Trat. e Distrib. de Água & 87,55 & 19,2 & & 0 & & 0 & & 0 & 87,55 \\
\hline 5 & Máq., Aparelhos e Materiais Elétricos & 62,48 & 13,7 & 22,12 & 2,28 & & 0 & & 0 & 84,6 \\
\hline 6 & Edição, Impressão e Gravações & 6,56 & 1,44 & 77,77 & 8,01 & & 0 & & 0 & 84,33 \\
\hline 7 & Eletricidade, Gás e Água Quente & & 0 & 80 & 8,24 & & 0 & 0,07 & 1,2 & 80,07 \\
\hline 8 & Alimentos e Bebidas & 26,14 & 5,72 & 14,79 & 1,52 & 6,56 & 3,97 & & 0 & 47,49 \\
\hline 9 & Móveis e Indústrias Diversas & 28,86 & 6,32 & 4,5 & 0,46 & 0,67 & 0,41 & & 0 & 34,03 \\
\hline 10 & Produtos Farmacêuticos & 7,2 & 1,58 & 16,7 & 1,72 & & 0 & 0,8 & 13,7 & 24,7 \\
\hline 11 & Metalurgia Básica & 20,06 & 4,39 & & 0 & & 0 & & 0 & 20,06 \\
\hline 12 & Borracha e Plástico & 2,68 & 0,59 & 8,02 & 0,83 & 7,69 & 4,66 & & 0 & 18,39 \\
\hline 13 & Equip. Médicos, Ópticos, de Automação e Precisão & 14,34 & 3,14 & & 0 & & 0 & & 0 & 14,34 \\
\hline 14 & Produtos de Metal (exclusive máq. e equip.) & 1,22 & 0,27 & 10,54 & 1,09 & & 0 & & 0 & 11,76 \\
\hline 15 & Outros Equip. de Transporte & 10,71 & 2,34 & & 0 & & 0 & & 0 & 10,71 \\
\hline 16 & Aeronáutica & & 0 & 9,81 & 1,01 & & 0 & & 0 & 9,81 \\
\hline 17 & Papel e Celulose & 2,39 & 0,52 & & 0 & 1,55 & 0,94 & 3,96 & 67,7 & 7,9 \\
\hline 18 & Reciclagem & & 0 & 1,08 & 0,11 & & 0 & & 0 & 1,08 \\
\hline 19 & Construção & & 0 & 1 & 0,1 & & 0 & & 0 & 1 \\
\hline 20 & Produtos Químicos & 0,15 & 0,03 & & 0 & 0,37 & 0,22 & & 0 & 0,52 \\
\hline 21 & Vestuário e Acessórios & 0,46 & 0,10 & & 0 & & 0 & & 0 & 0,46 \\
\hline \multirow[t]{3}{*}{22} & Máq. Escrit. e Equip. Informática & & 0 & & 0 & 0,1 & 0,06 & 0,11 & 1,88 & 0,21 \\
\hline & TOTAIS & 456,96 & & 970,67 & & 165,05 & & 5,85 & & \\
\hline & TOTALGERAL & 1598,53 & 28,6 & & 60,7 & & 10,3 & & 0,37 & \\
\hline
\end{tabular}

Fonte: Fundação Seade; Pesquisa de Investimentos de SP - PIESP. (Jan/2010)

Elaboração: Michel Soares R. da Silva (acesso em 06/02/2010)

$\mathrm{Na}$ tabela 9 foi possível observar que entre as dez atividades iniciais, somente as três primeiras, Máquinas e Equipamentos, Automotiva e Material Eletrônico e Equipamentos de Comunicação, apresentam investimentos na ampliação, implantação e modernização, com investimentos superiores a US\$ 
160,00 milhões, sendo pertinente levar em consideração a implantação do Parque Tecnológico de Sorocaba.

Entre a quarta e a décima primeira atividade, os investimentos orçados estão entre US\$20,00 e US\$ 87,55 milhões, com notório destaque na ampliação das atividades de Captação, tratamento e distribuição de água e máquinas, aparelhos e materiais elétricos, nos faz pensar que esse tipo de investimento se realiza com a função de viabilizar a implantação de outras empresas sejam elas do ramo industrial ou do setor de serviços. Afinal, para a instalação da Toyota em Sorocaba, investimento de US\$ 600 milhões, obras em ampliação e melhorias no fornecimento de água e de energia elétrica foram anunciadas e realizadas para estruturar e melhor equipar a cidade para atender o dinamismo econômico atual.

Assim, mesmo havendo uma diversidade em suas atividades, a partir do desenvolvimento em determinados segmentos do ramo industrial, de certa maneira, indicam os investimentos em outros setores complementares, fundamentais para que a cidade possa ser estruturada para atender as demandas necessárias. Essas demandas as quais nos referimos vão desde a infraestrutura básica para os diversos setores da economia como água, energia elétrica, vias de acesso e telecomunicação, como também as ligadas a habitação, a educação e a qualificação profissional, garantindo assim a reprodução da força de trabalho necessária ao desenvolvimento industrial.

Sobre os investimentos em modernização os valores atribuídos não ultrapassam os US\$ 170 milhões, sendo que, os mais expressivos, são as atividades automotiva (US\$ 79,4 milhões) e a de material eletrônico e 
equipamento de comunicação (US\$ 60 milhões), também fazendo parte das primeiras atividades que compartilham os maiores investimentos. $\mathrm{Na}$ atividade automotiva, dos US\$ 79,4 milhões, a maior parte provem da General Motors (US\$ 70 milhões) e da Sandivik Hurth (US\$ 4,35 milhões). Já os US\$ 60 milhões da atividade ligada a material eletrônico e equipamentos de comunicação, o investimento foi realizado pela Flextronics.

Conforme já havíamos comentado anteriormente, os investimentos em pesquisa e desenvolvimento nos chamam a atenção pelo menor investimento disponibilizado, totalizando US\$ 5,85 milhões e a maior parte, US\$ 3,96 milhões $(67,7 \%)$, realizados pela Metso Papers.

Harvey (1989:101) afirma que "o capitalista tem o poder de mobilizar os poderes da cooperação, da divisão do trabalho e do maquinário como poderes do capital sobre o trabalho", mas analisando a tabela $9 \mathrm{em}$ sua totalidade e levando em consideração os aspectos das atividades industriais desenvolvidas na cidade de Sorocaba", podemos concluir que o poder do capitalista não fica apenas restrito ao trabalho. Ao que tudo indica esse poder se articula com outros elementos, ou seja, aos tipos de investimentos, determinando onde, quando e como os realizará. Sendo assim, a partir do que discutimos até o momento, trataremos no próximo capítulo, mais especificamente do bairro do Éden e das indústrias que estão presentes em sua área, bem como das relações existentes para a reprodução do capital e suas consequências sociais. 


\section{2- O bairro do Éden e as indústrias}

Localizado na região nordeste e distante cerca de $15 \mathrm{~km}$ em relação ao centro da cidade de Sorocaba, o Éden fazia parte das terras devolutas pertencentes ao Estado de São Paulo e com a Lei Municipal no 539 de 17 de dezembro de 1957, passa a ser denominada inicialmente como "Vila Éden".

Constituído inicialmente por famílias de agricultores, chácaras e sítios, foram registrados 2019 habitantes, segundo Censo Demográfico de 1970, realizado pelo IBGE.

Com características rurais e uma grande extensão de terras disponíveis tornara-se viável para investimentos. Como o distrito de Votorantim consegue sua autonomia e passa a ser município, Sorocaba perde os recursos fiscais advindos de Votorantim e assim novas decisões são tomadas pela administração municipal de Sorocaba. Como uma estratégia de desenvolvimento, cria uma Zona Industrial em Sorocaba na qual o Éden e outros bairros próximos passam a fazer parte. Deste modo, aos poucos uma área com características rurais foi se transformando e passando a desempenhar uma função mais urbana-industrial.

Essa nova função exigiu que fossem realizadas transformações no bairro de modo que a produção pudesse ser viabilizada. Uma nova realidade espacial aparece: boa parte das ruas é pavimentada, surge e ou se amplia 0 sistema de abastecimento água e coleta de esgoto, iluminação nas ruas, sem esquecer o estabelecimento de loteamentos para fins residenciais e comerciais, além das áreas destinadas para a instalação de indústrias.

Atualmente, em seu perímetro urbano, apresenta infraestrutura básica como o fornecimento de água, energia, serviço telefônico, etc, para a maior 
parte de seus moradores. Também se beneficiam da infraestrutura básica as pequenas empresas prestadoras de serviços; o setor comercial que é diversificado com lojas de materiais para construção, elétrica, vestuário, alimentício, entre outros; está presente ainda, o setor de prestação de serviços com escritórios de advogados, de contabilidade, dentistas, transportadoras, além dos serviços bancários e imobiliários.

Há de se considerar que no bairro com tantas transformações que ocorreram e ainda ocorrem, foi auferida uma dinâmica urbana com o aumento da circulação de automóveis e de pessoas que realizam negócios nos diversos setores da atividade econômica promovendo o movimento da lógica capitalista.

O bairro do Éden, concentra um bom número de indústrias da cidade de Sorocaba junto com os bairros Cajurú do Sul e Aparecidinha, conforme demonstrado no mapa 1 do município e segundo o Plano Diretor ${ }^{16}$ vigente que instituiu, no Artigo $22^{17}$, a Zona Industrial.

\footnotetext{
${ }^{16}$ Plano Diretor do município de Sorocaba conforme LEI № 8.181, DE 05 DE JUNHO DE 2007 contendo revisão da Lei 7.122 de 04/6/2004 que instituiu o novo Plano Diretor de Desenvolvimento Físico Territorial do Município de Sorocaba, e dá outras providências. Site: www.sorocaba.sp.gov.br (acesso em 05/10/2009)

${ }^{17}$ Art. 22. Nas Zonas Industriais - ZI, composta por áreas com concentração industrial já estabelecida e áreas a serem destinadas para expansão destas atividades, as normas de parcelamento, uso e ocupação do solo e outras providências.
} 


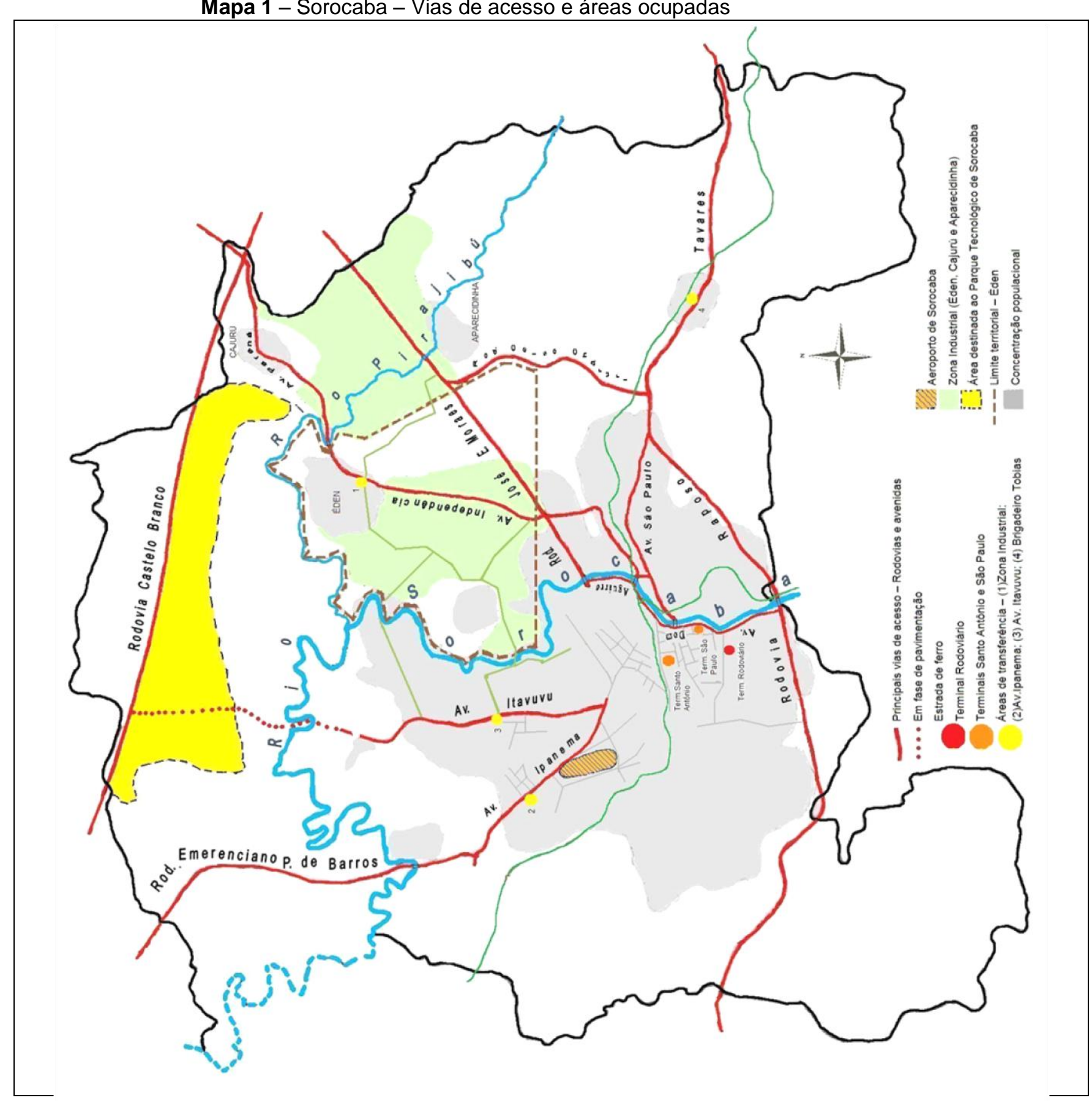

Adaptado do mapa de zoneamento da cidade de Sorocaba.

Elaboração: Michel Soares R. da Silva 
Conforme citado, a existência dessa zona industrial está associada ao planejamento que a cidade iniciou já na década de 1960, ampliando a concentração de indústrias nessa parte da cidade a partir dos anos de 1970, impulsionada pela desconcentração industrial ocorrida no Estado de São Paulo da capital paulista para o interior.

Levando-se em consideração o bairro do Éden, as indústrias ali instaladas, cerca de 243 - entre elas indústrias de peças e acessórios, tratores e máquinas, artefatos de plástico e borracha, ferro e metal, química e farmacêutica, metalúrgica e serviços - e a cidade como um todo, há o estabelecimento de relações constantes em função das necessidades e interesses em comum, o que não poderia ser diferente, associando produção, consumo, geração de empregos e sem sombras de dúvidas a movimentação da economia do município. Ainda nessa perspectiva, essa relação não se processa de forma isolada, no interior do município, toma proporções que possibilitam a ligação com outros lugares, não só a nível estadual, mas também nacional e internacional. Basta fazer a análise quando Carlos (2007) escreve que:

O capitalismo, o estado e o espaço mundializam-se, o mercado mundial permite a convergência dos fluxos de informação e de mercadorias. O capitalismo constitui-se em totalidade contornando, destruindo, e absorvendo obstáculos, destruindo fronteiras. No processo de globalização o lugar ganha um novo conteúdo, produz-se uma hierarquia diferencial dos lugares que aparece sob a forma de uma competição entre lugares pelo investimento (CARLOS, 2007, p.32).

Portanto, quando observamos a existência de ações públicas que, a partir da década de 1960, traçam diretrizes por meio de leis e decretos para se instituir, por exemplo, o zoneamento da cidade, nos reforça a ideia da ligação entre os lugares que se estabelecem a todo o momento, como afirma Carlos, 
"produzindo uma hierarquia diferencial dos lugares", o que nos faz pensar sobre as estratégias adotadas pela gestão pública de uma cidade a qual se organiza com plena consciência direcionando as ações de uma política pública competitiva entre os lugares para atrair investimentos e as possíveis consequências para a sociedade.

Com vistas nas estratégias adotadas pela gestão pública podemos observar que as interferências nos diversos bairros da cidade são direcionadas de acordo com as metas constituídas, onde cada um deles desempenha suas funções, como por exemplo, a Zona Industrial, a qual o bairro do Éden faz parte, e executa sua função enquanto área determinada para a realização da lógica da produção/reprodução do capital por meio da produção industrial, lugar este que reúne condições básicas de infraestrutura como fornecimento de água, de energia elétrica, meios de comunicação e sistema de transporte para que haja sua realização.

A presença da infraestrutura existente no bairro do Éden, oferecida para as indústrias inseridas em sua extensão, são requisitos básicos para a instalação industrial. A isso se acrescenta outras condições que podem ter auxílio do poder público, como exemplo, a concessão de terreno como aconteceu em Sorocaba na Zona Industrial e a isenção de impostos, além dos investimentos da própria empresa para que possam conduzir suas atividades produtivas de forma lucrativa, como exemplo, a capacitação de funcionários.

Há de se considerar que a relação entre bairro-indústria gerou transformações na organização espacial, surgindo novas atividades econômicas de prestação de serviços e comerciais, que pelo menos nos anos compreendidos entre a década de 1970 quando as indústrias iniciavam suas 
instalações e início da década de 1990 quando se tornam mais expressivas. As atividades econômicas que foram sendo incorporadas estão ligadas inicialmente ao comércio de material de construção, mercados, lojas de roupas, entre outras, reunindo a partir da década de 1980-1990 outras atividades como o surgimento de pequenas empresas prestadoras de serviços complementares na execução de usinagem de materiais ferrosos, aluguel de salões comerciais para empresas prestadoras de serviços como advogados, dentistas, lojas de roupas, papelaria, galpões de pequenas empresas de usinagem e estoque de mercadorias, oficinas mecânicas, além de outras atividades.

Juntamente com as atividades citadas anteriormente, o setor imobiliário ${ }^{18}$ ganha proporções significativas devido a nova organização espacial amparada pelo Plano Diretor Municipal propiciando condições para que investidores passassem a comprar terrenos para construir residências destinadas a venda ou aluguel, salas comerciais e galpões para alugar como forma de obter vantagem da nova realidade do bairro, antes constituído por residências e chácaras.

Para ilustrar a atual situação as fotos de 1 a 5 são exemplos da atual configuração do bairro que durante os anos vem se adequando intensamente às possibilidades de crescimento para obtenção de lucro.

\footnotetext{
${ }^{18}$ No início dos anos de 1980 o bairro contava com apenas 2 imobiliárias. Em maio/2011 realizamos um levantamento e computamos 18 imobiliárias.
} 


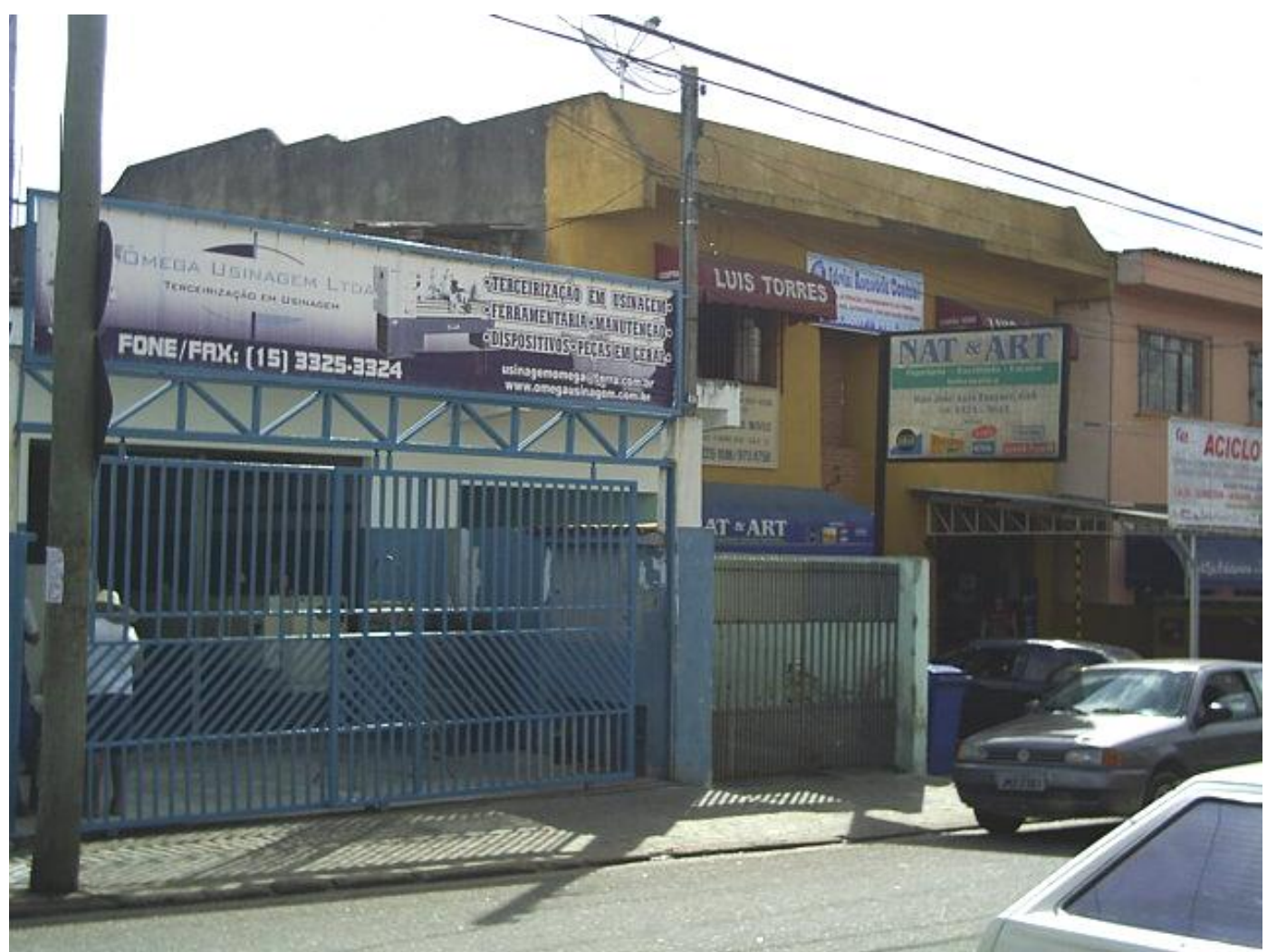

Foto 1: Rua José Luiz Flaquer - Galpões/ salões comerciais

Autor: Michel Soares R. da Silva - Data: 20/01/2010

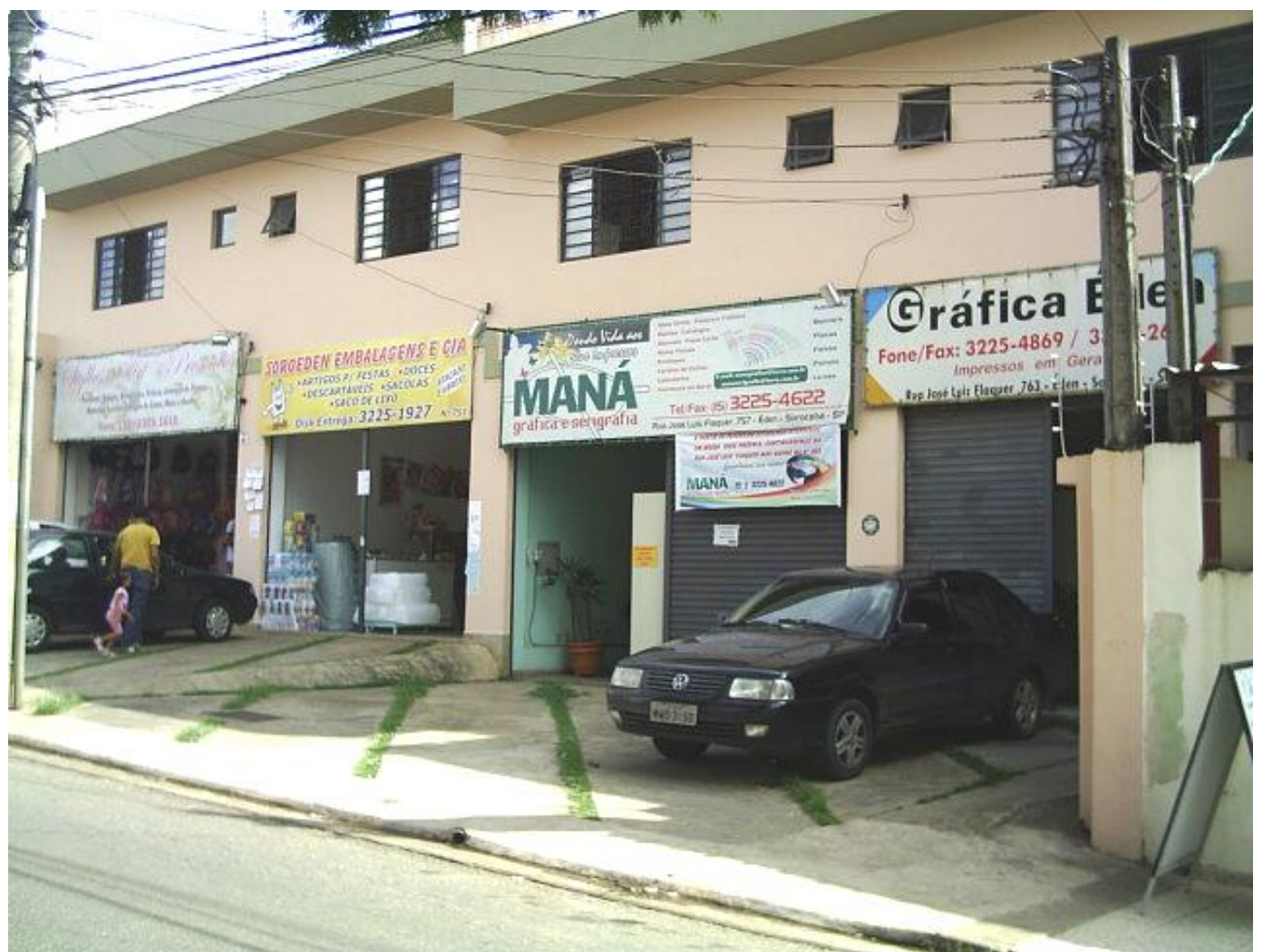

Foto 2: Rua José Luiz Flaquer - Galpões/ salões comerciais Autor: Michel Soares R. da Silva - Data: 20/01/2010 


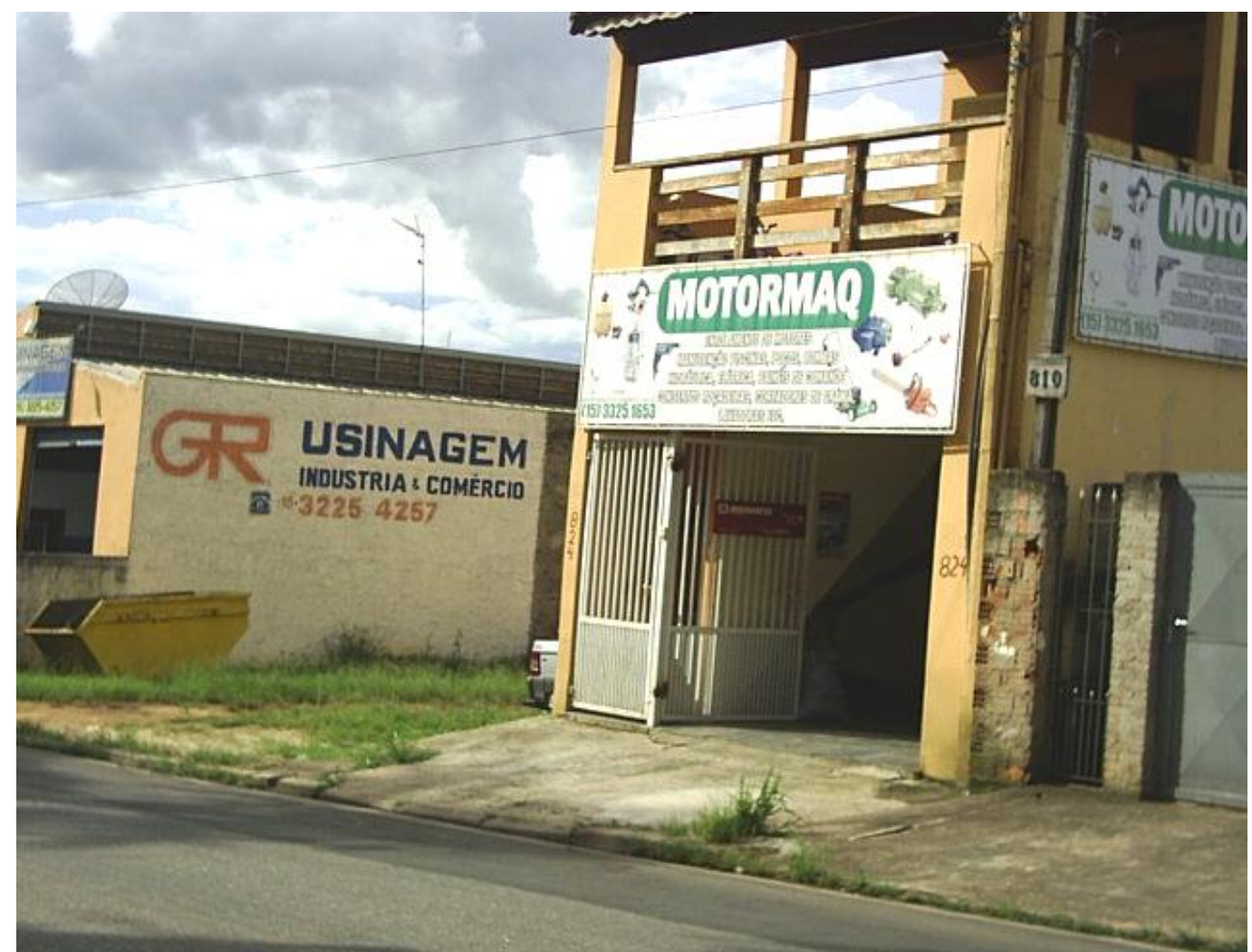

Foto 3: Rua José Luiz Flaquer - Galpões

Autor: Michel Soares R. da Silva - Data: 20/01/2010

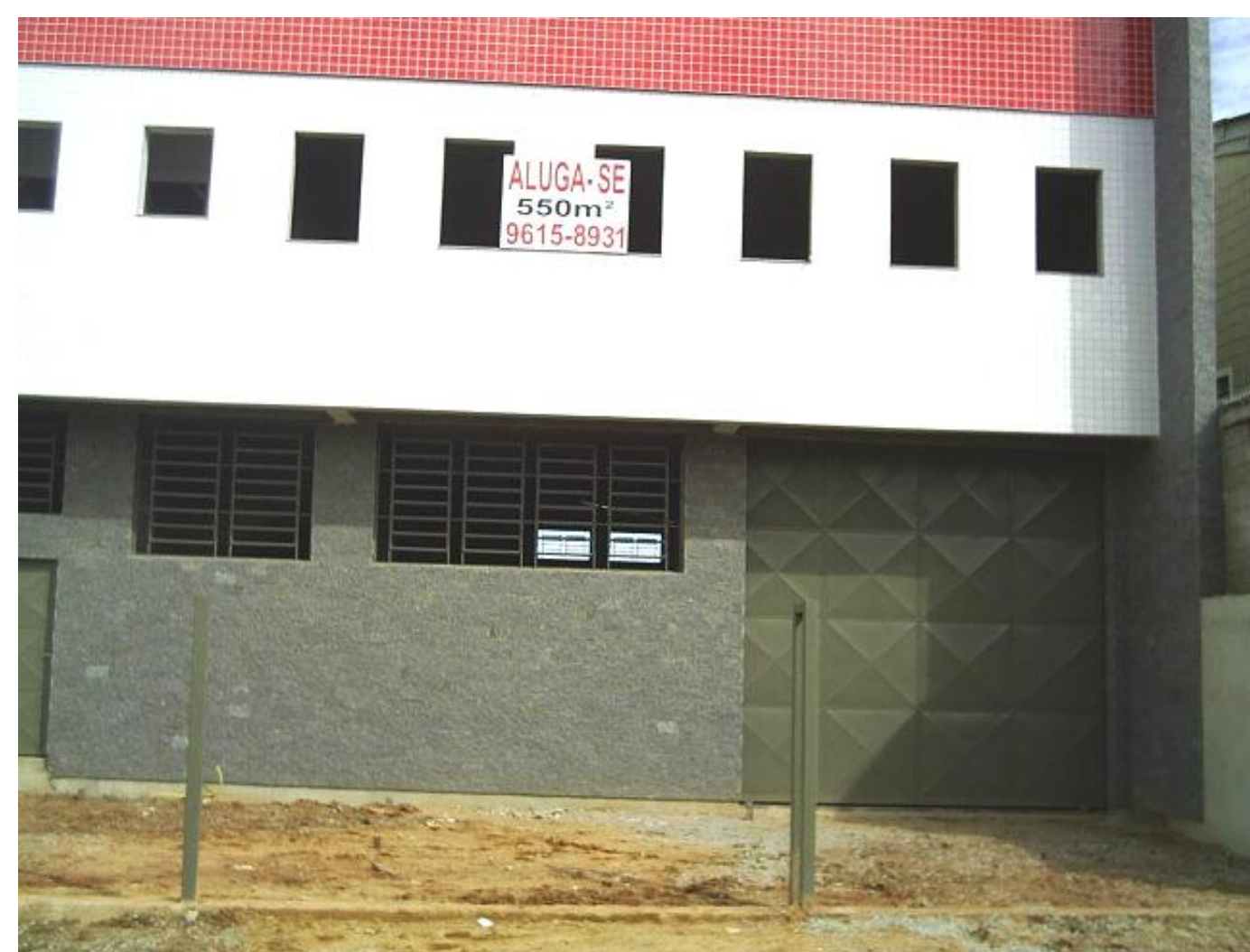

Foto 4: Rua José Raimundo de Andrade - Imóvel para aluguel Autor: Michel Soares R. da Silva - Data: 20/01/2010 


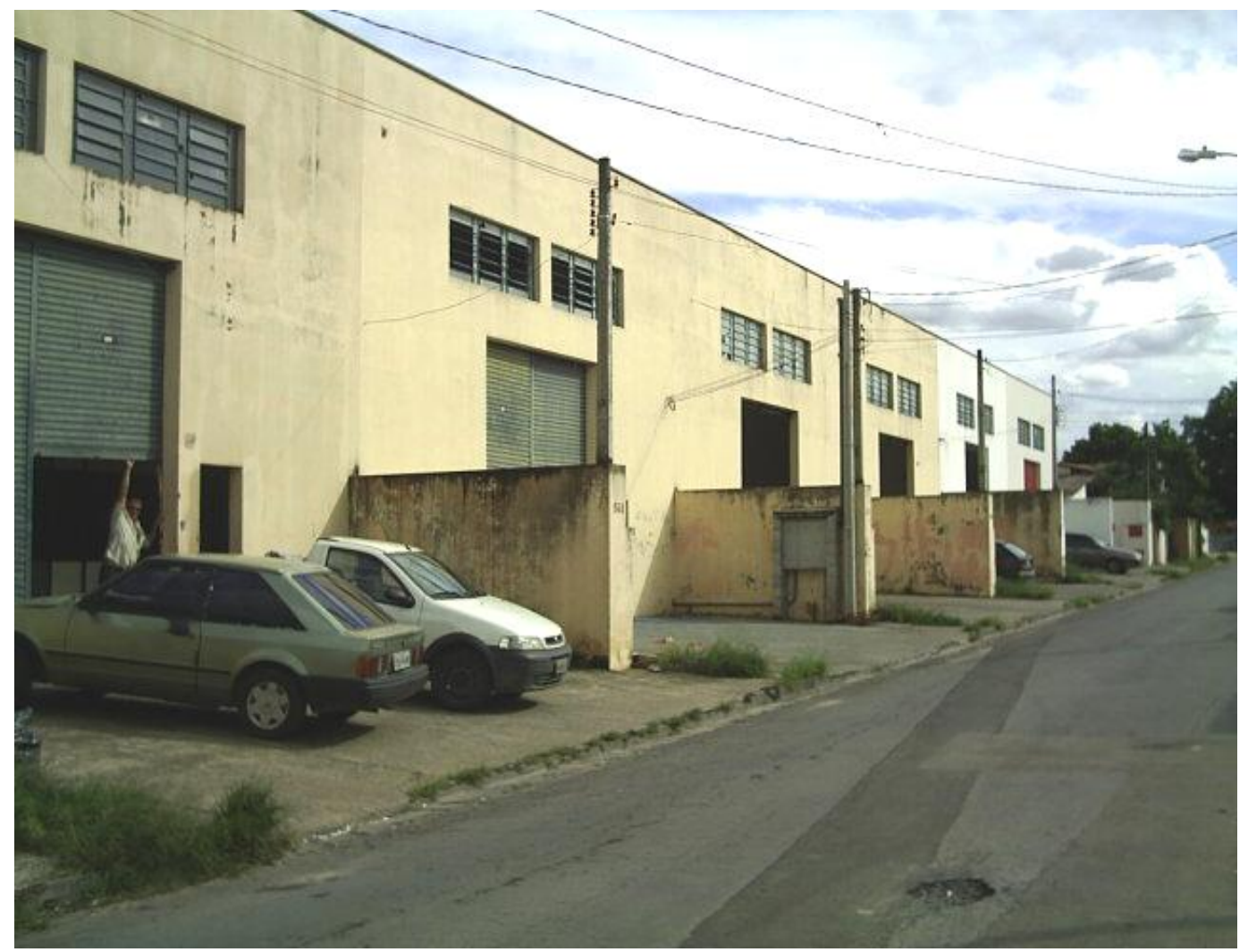

Foto 5: Rua Luiz Gonçalves de Camargo - Galpões alugados

Autor: Michel Soares R. da Silva - Data: 20/01/2010

Como podemos observar nas fotos, há uma variedade de elementos que

comprova a dinâmica existente no bairro que sofreu influência com a presença

das indústrias o que nos parece ir ao encontro quando Santos afirma que:

A internalização do externo não se dá de forma arbitrária, mas em lugares específicos, onde podem combinar-se as variáveis internas com as externas. A combinação entre o externo e o interno depende de uma articulação entre essas diferentes variáveis, e daí cria-se um novo precipitado. Tudo o que existe num lugar está em relação com os outros elementos desse lugar. O que define um lugar é, exatamente, uma teia de objetos e ações com causa e efeito, que formam um contexto e atinge todas as variáveis já existentes, internas; e as novas, que se vão internalizar (2001, p.97).

Sendo assim, quando levamos em consideração todo o processo de industrialização de Sorocaba dos últimos 40 anos, a combinação de objetivos nacionais que estavam vinculados a uma organização mundial, passando pela 
desconcentração da indústria da capital paulista e, paralelo a isso, Sorocaba preparando-se para constituir-se como uma cidade do interior para receber investimentos da indústria e de outras atividades econômicas, criou a possibilidade de reorganização espacial do Éden, associando as áreas residencial, comercial e industrial que se interligam, combinando-se, articulando-se, diante das influências externas e internas, o que acaba determinando uma hierarquia.

Até o momento expusemos com maior ênfase as questões ligadas ao sistema produtivo e aos serviços, mas há de se analisar o setor residencial como elemento constitutivo do processo de transformação que ganhou evidência pelo menos nos últimos 10 ou 15 anos no bairro do Éden com o surgimento de vários loteamentos e o lançamento de condomínios fechados (foto 6).

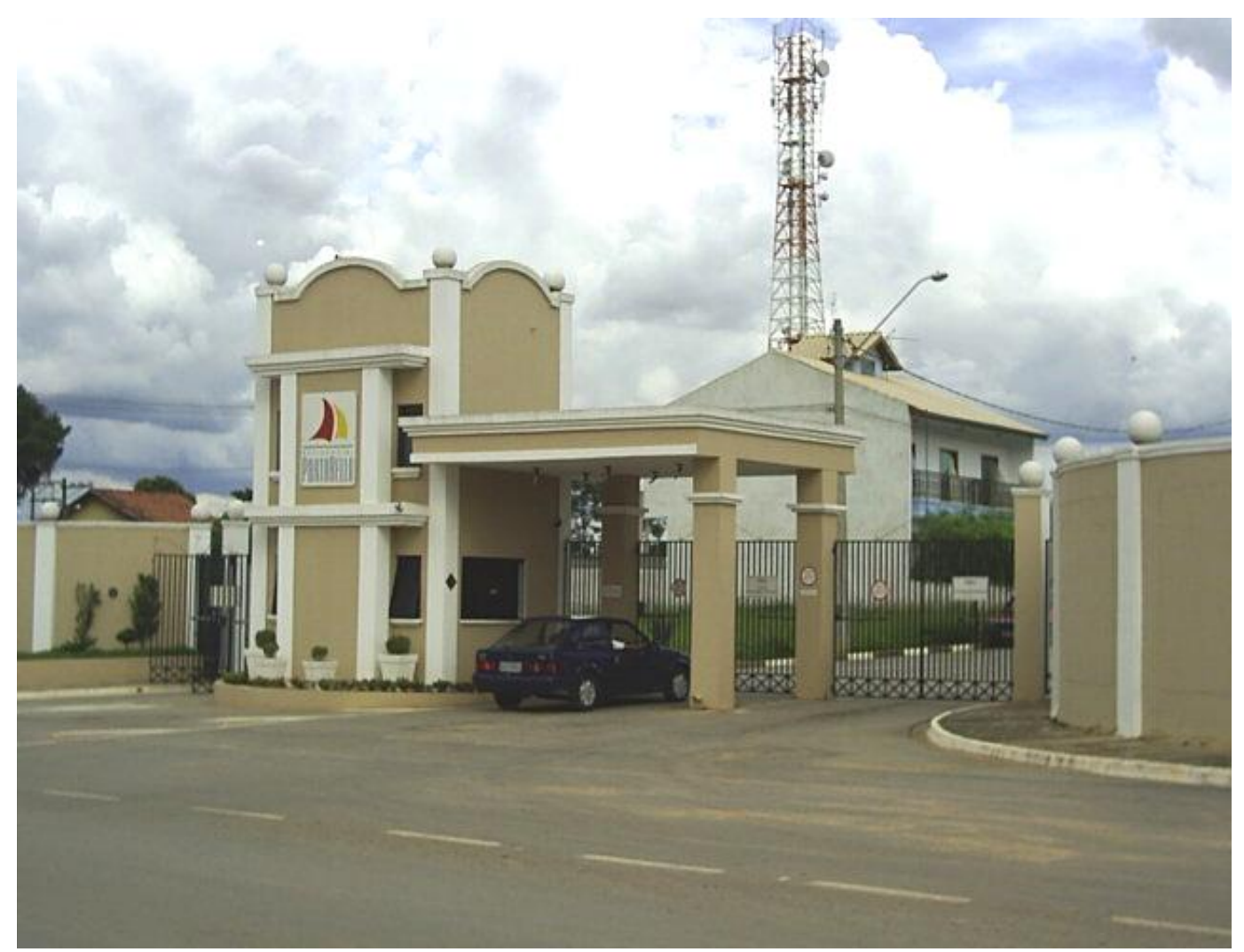

Foto 6: Condomínio Portobello

Autor: Michel Soares R. da Silva - Data: 20/01/2010 
Durante o processo de transformação do bairro e de acordo com as intenções da administração municipal, a reorganização espacial aconteceria de forma gradual e a combinação entre as casas e chácaras que existiam cederiam espaço para outros empreendimentos, entre os já citados, comércio e serviços, mas também ao residencial (foto 7). Da mesma forma que aumentou a presença do comércio e dos serviços, segundo o Plano Diretor, Art.20 itens I e II, embora haja predominância residencial, admite usos não residenciais, normatizando assim o que já existia e permitindo a expansão de diversas atividades não residenciais, promovendo o uso do solo de forma racional. Essa caracterização passa a se chamar Zona Residencial 3 (ZR 3).

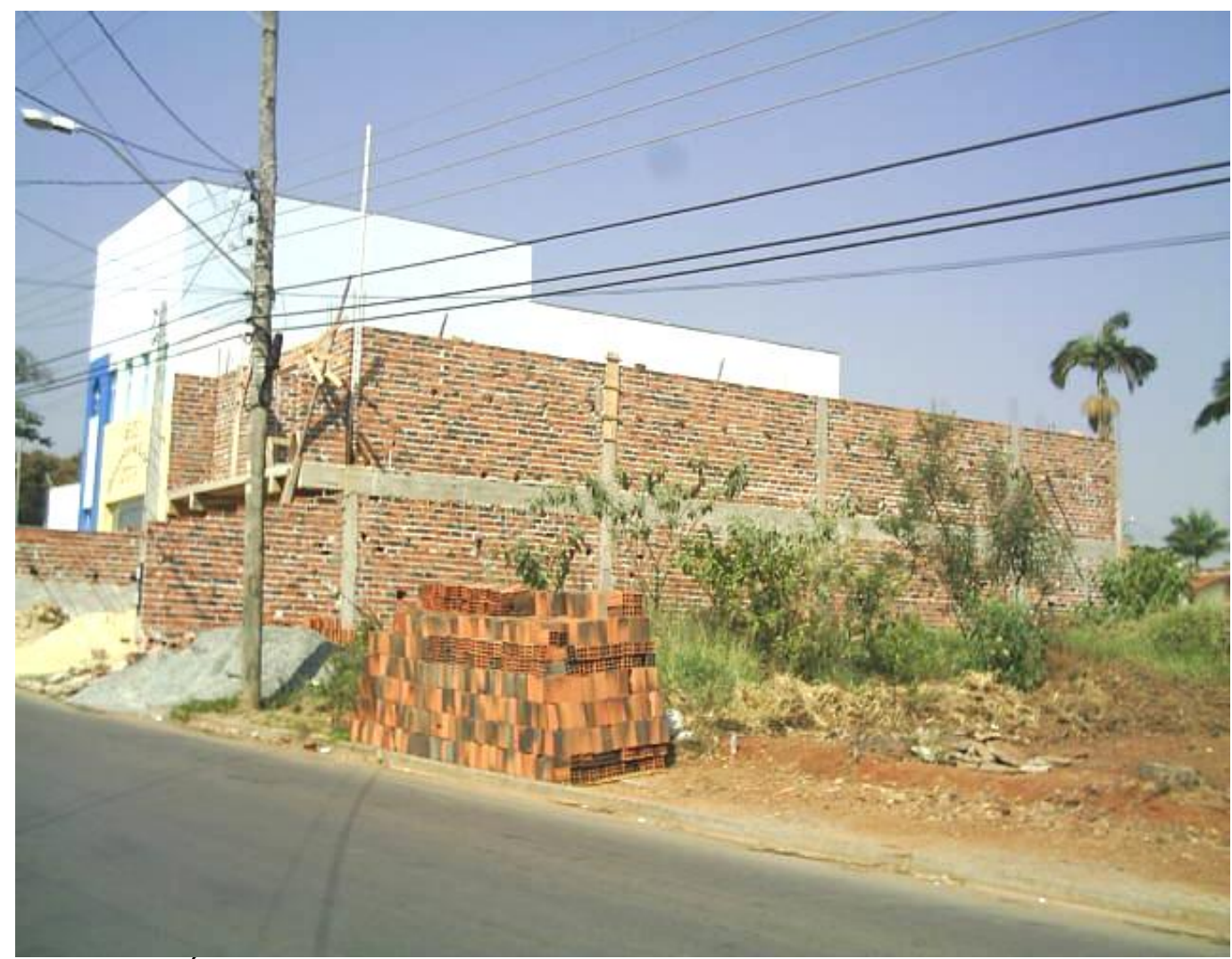

Foto 7: Área de uma antiga chácara que aos pouco está cedendo espaço ao comércio e à residência

Autor: Michel Soares R. da Silva - Data: 06/07/2008 
Para debater sobre as questões residenciais acreditamos ser importante direcionar a discussão a partir das possíveis causas geradoras dos problemas que a população do bairro enfrentava antes e após a criação da Zona Industrial e, por conseguinte a instalação das indústrias. É o que será desenvolvido no item a seguir.

\section{1- Os problemas enfrentados pela população do bairro: uma breve análise}

Em Sorocaba, e em especial o bairro do Éden, também há problemas que geram inquietações e grandes discussões a respeito das possíveis soluções que possam promover mudanças positivas, minimizando assim os impactos negativos, como por exemplo, os relacionados ao atendimento médico-hospitalar e a segurança pública, aspectos comuns quando ocorre o aumento da população, na busca em propiciar uma qualidade de vida mais adequada para a população.

Há pelo menos trinta anos atrás alguns dos problemas enfrentados pelo bairro eram: pavimentação de ruas, iluminação pública, carência de atendimento médico, deficiência no fornecimento de água, a quase inexistência do setor comercial causando dependência do centro da cidade, ausência de bancos e a precariedade no transporte público. Naquele momento esses pareciam ser os problemas mais latentes ao mesmo tempo em que a instalação das indústrias já ocorria e a circulação e fixação de pessoas no bairro aumentavam com o passar dos anos. 
Neste contexto surge um questionamento: Em quais condições se encontra a população do bairro do Éden atualmente, após o chamado crescimento industrial na área? Podemos dizer que os problemas enfrentados hoje são muito semelhantes ao passado, com relação ao atendimento à população residente. Isso não é particular a Sorocaba. Esse fenômeno está presente em várias cidades brasileiras, onde quanto mais distante da área central da cidade o conjunto de carências na infraestrutura desses bairros, como por exemplo, precariedade no transporte coletivo, iluminação pública, fornecimento de água, atendimento médico-hospitalar, escola, etc, continuam inerentes aos lugares. Em geral, a prioridade no atendimento às demandas está relacionada a investimentos ligados ao desenvolvimento econômico, não conseguindo assim atender a grande maioria da população, dificultando a construção de ações e soluções para termos a diminuição de tais problemas. Sendo assim, surge cada vez mais uma constante batalha por parte da população e de algumas entidades do bairro na tentativa em se organizar e requisitar melhorias que possam justificar uma condição de vida adequada ao ser humano.

Para analisar o caso do bairro do Éden, atualmente, pelo que pudemos apurar, a população passa por um processo de descontentamento muito grande frente à gestão pública pelas promessas de soluções que não são cumpridas há anos. Exemplo foi a Plenária de Participação Cidadã ${ }^{19}$ de junho de 2008 em que a solicitação dos munícipes era o cuidado com as estradas no entorno do bairro por estarem precárias, duplicação de avenidas, cuidado com

\footnotetext{
${ }^{19}$ A "Plenária de Participação Cidadã" que ocorre anualmente desde 2006 é um evento promovido pela Prefeitura Municipal com o objetivo em obter informações sobre as necessidades dos bairros. A partir das carências indicadas pela população local as mesmas são estudadas e algumas delas farão parte do orçamento do município para o ano subsequente. Em 2010 passa a ser denominada "Orçamento no Bairro."
} 
as praças locais que estavam sem manutenção e servindo como ponto de encontro de meliantes, construção de creche e escola, pois as existentes já não atendem a demanda necessária e a preocupação com o meio ambiente devido ao sistema de abastecimento de água do bairro e suas adjacências correrem risco de diminuir suas reservas devido o uso inadequado das áreas de mananciais e a poluição do rio Pirajibú que atravessa o bairro.

Com esses exemplos dos problemas debatidos na Plenária de 2008, a promessa em buscar soluções para algumas delas rendeu a reeleição para o segundo mandato à Prefeitura de Sorocaba e ao chegar no ano de 2009 na Plenária de Participação Cidadã no mês de setembro e a de junho de 2010, já com o nome de "Orçamento no Bairro", as solicitações praticamente foram as mesmas contrariando as promessas anteriores e pouco avançando nas ações para melhorar o atendimento a população.

Levantando um questionamento muito proeminente nas Plenárias de Participação Cidadã dos últimos anos, perguntamos: Já que o bairro do Éden é uma área industrial, assim como os bairros adjacentes (Cajurú do Sul e Aparecidinha), participando de uma arrecadação de impostos significativa para o município, por que há carência no atendimento de alguns serviços básicos como escolas, atendimento médico-hospitalar, pavimentação e manutenção de algumas ruas, duplicação de vias de acesso às rodovias para escoamento de mercadorias e circulação de pessoas, desenvolvimento de projetos culturais, e outros?

Como há de se constatar, parece haver um sentimento de injustiça, pois também se faz comparações com outras áreas da cidade recebedoras de investimentos que, aparentemente, não são realizados em acordo com as 
carências existentes no bairro. Podemos exemplificar o caso quando em meados de 2008 foi inaugurada a Praça Kassato Maru (fotos 1, 2 e 3), na zona sul e área considerada nobre da cidade, no bairro Campolim, em homenagem ao centenário da imigração japonesa no Brasil. No mesmo período de inauguração, a população renovava a solicitação da duplicação de uma via pública, Avenida Victor Andrew (foto 4), trecho que liga a zona industrial (nordeste) da cidade a zona norte com trânsito intenso e perigoso, trecho de constante deslocamento de mercadorias e pessoas.

Não pretendemos dizer com isso que a questão cultural deva ser deixada de lado, mas as questões de atendimento direto às condições de circulação da população e de mercadorias fiquem subordinadas ou condicionadas a interesses maiores tendo em vista que se trata de uma área perigosa para a população que faz uso dessa via pública.

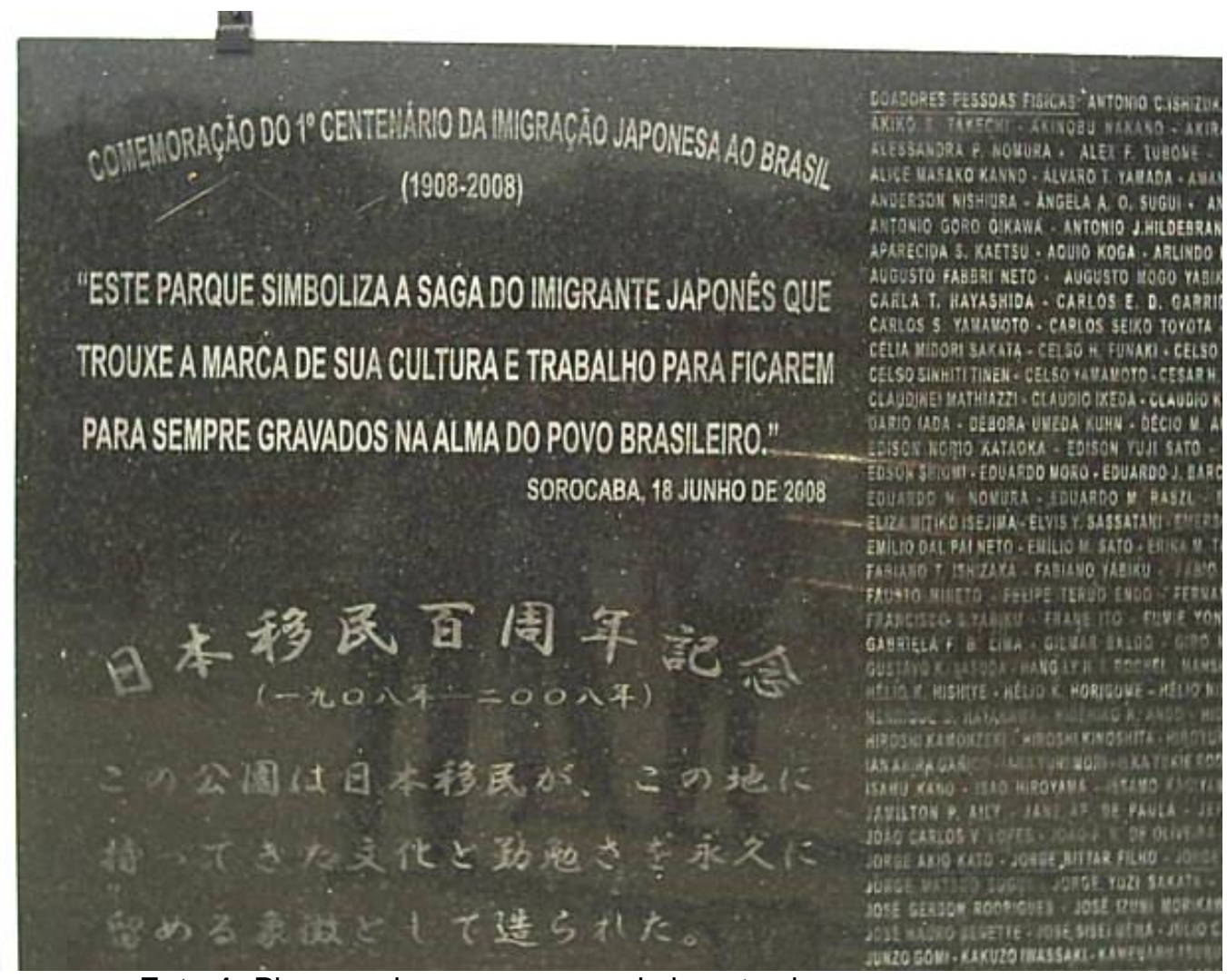

Foto 1: Placa em homenagem aos imigrantes japoneses

Autor: Michel Soares R. da Silva - Data: 06/07/2008 


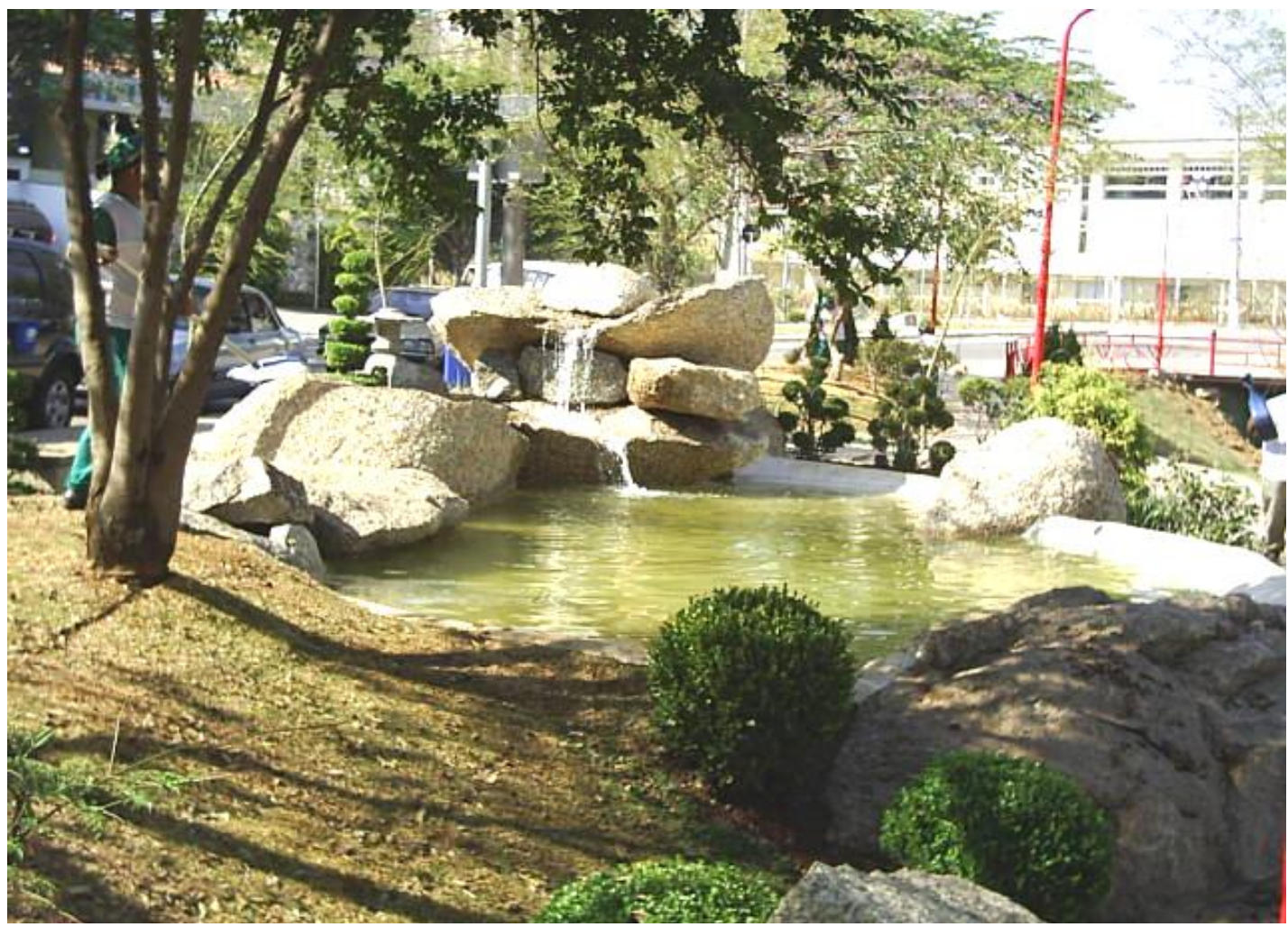

Foto 2: Chafariz da Praça Kassato Maru

Autor: Michel Soares R. da Silva - Data: 06/07/2008

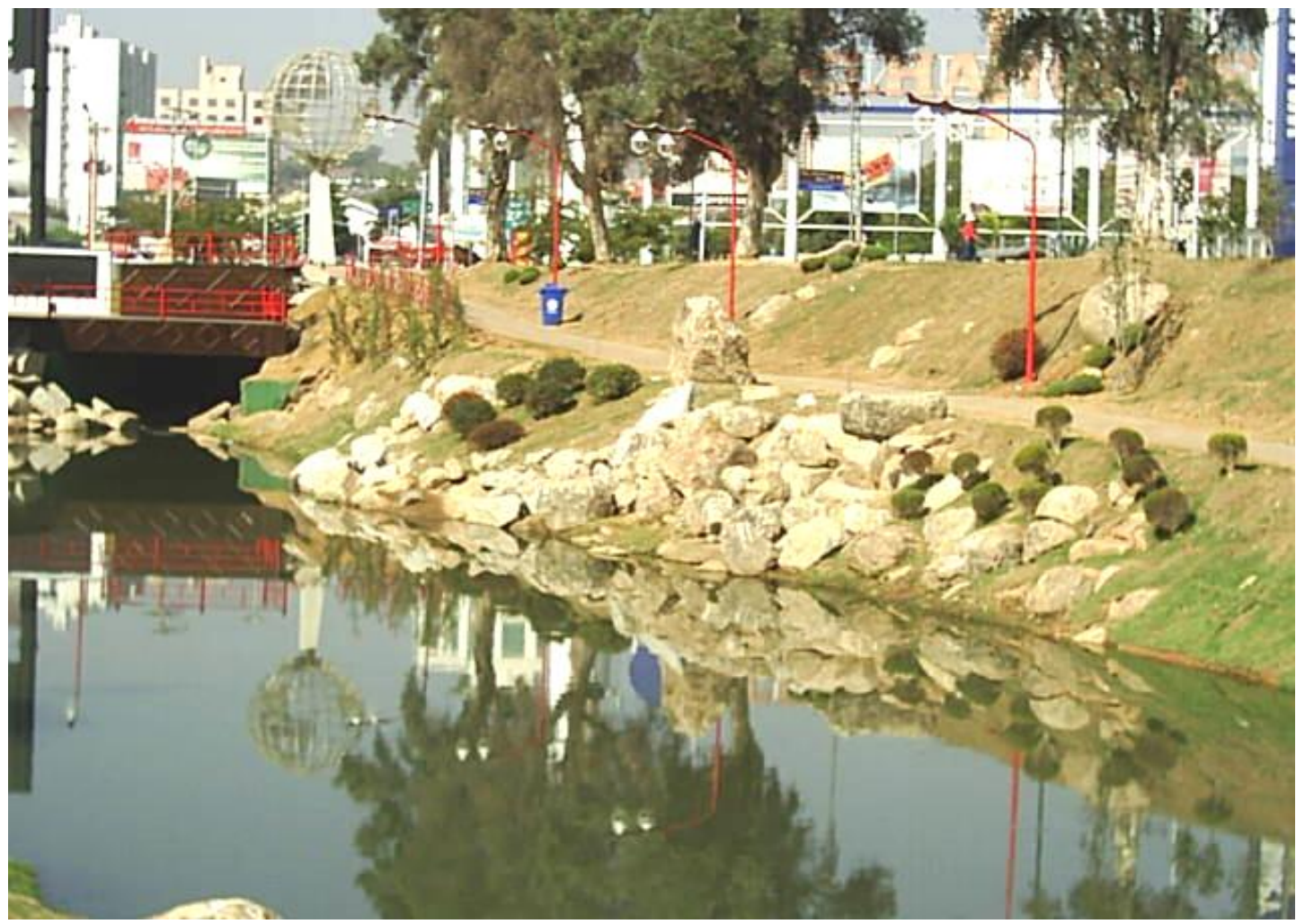

Foto 3: Parte da praça que mostra córrego e pista de caminhada à direita da foto Autor: Michel Soares R. da Silva - Data: 06/07/2008 


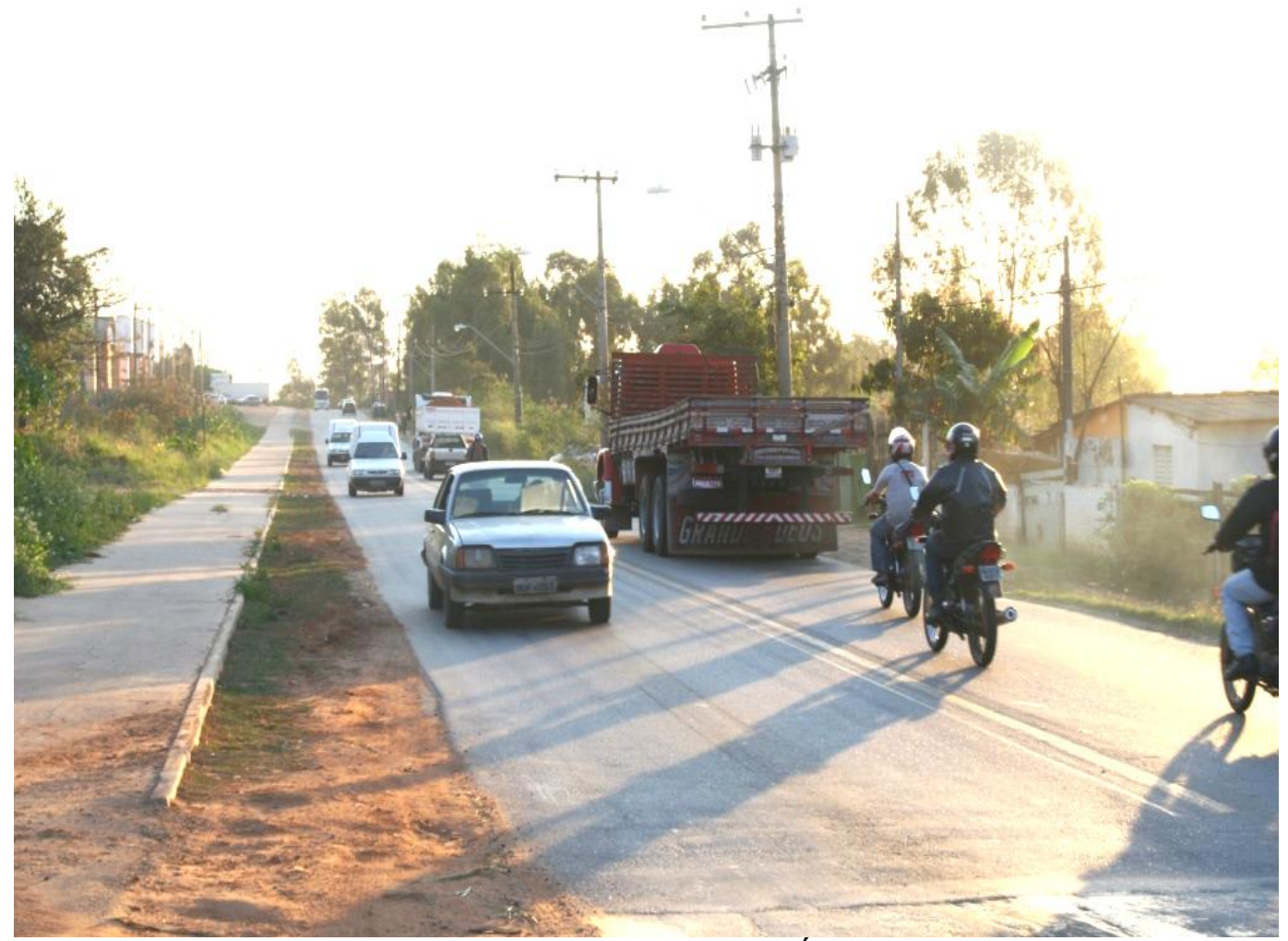

Foto 4: Avenida Victor Andrew um dos acessos Éden - Zona norte e centro Autor: José Bernardo da Silva - Data: 02/09/2009

Como podemos verificar na foto 4 , a circulação pela Avenida Victor Andrew em determinados horários torna-se perigosa, pois não há acostamento para veículos e o espaço é reduzido para os trabalhadores que circulam em direção as empresas para desenvolverem suas atividades profissionais a pé ou de bicicleta pelo trecho a esquerda da foto que é considerada uma ciclovia.

$\mathrm{Na}$ Avenida Independência, principal via de acesso para as indústrias dos bairros do Éden e Cajurú, ligação entre Itu e Sorocaba, encontramos recentemente, início do ano de 2010, uma faixa (foto 5) que expressa a mesma preocupação dos moradores em anos anteriores com os cuidados que a administração pública deveria ter com as vias de acesso ao bairro. 


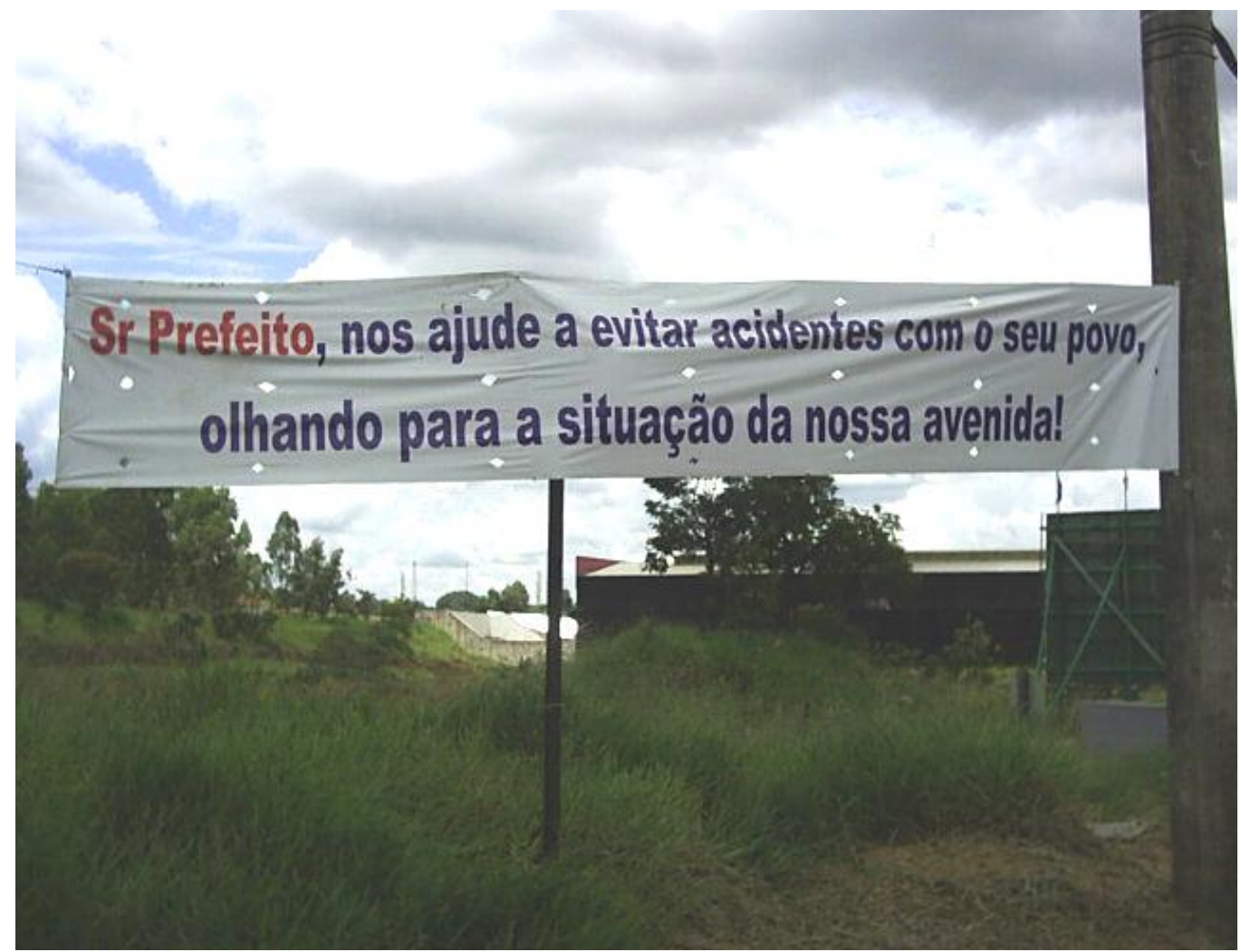

Foto 5: Faixa na Avenida Independência alertando a administração pública Autor: Michel Soares R. da Silva - Data: 26/01/2010

O comentário e a imagem anterior demonstram que mesmo depois de tantas solicitações e debates nas últimas três Plenárias com participação popular, parece que o tratamento atribuído ao bairro não está em acordo com o discurso em "olhar e zelar pelo bem estar social da população do bairro", sendo um sintoma da "socialização das desvantagens", citada por Carlos (2001, p.35). Devemos considerar que, guardadas devidas proporções, a socialização das desvantagens ocorrem nos diversos lugares, apresentando uma variedade de problemas que se compõem de formas e intensidades diferentes.

\section{2- Uma nova perspectiva para a Zona Industrial}

Após muitas discussões isoladas que ocorreram em anos anteriores por parte de diversos agentes políticos, empresários, associações e população local, interessados em melhorar as condições na infraestrutura da Zona 
Industrial, em 12 de março de 2010, na Câmara Municipal de Sorocaba, aconteceu uma Audiência Pública tendo como pauta do assunto "Infraestrutura da Zona Industrial". Nesse encontro estavam presentes representantes de indústrias locais, vereadores, o secretário de desenvolvimento econômico, associações e munícipes interessados.

No início do encontro foi apresentado um vídeo contendo relatos e imagens dos problemas apresentados nas vias públicas, desde a dificuldade no deslocamento de mercadorias e pessoas, pistas danificadas, a necessidade de duplicação de algumas vias e acidentes que colocavam em risco a população.

Após a apresentação desse vídeo, um empresário local relata os problemas enfrentados por sua empresa pela ausência de cuidados com as vias de circulação que se apresenta com buracos e intenso movimento em horários de pico, dificultando a circulação de mercadorias e o risco de acidentes proporcionando danos aos produtos e funcionários.

Com o exemplo desse relato, entre outros apresentados, as discussões durante a audiência pública, propiciaram a formação de um grupo de trabalho, composto por diversos agentes da sociedade (Sociedade Amigos de Bairro, Associação dos Empreendedores do Bairro do Éden e Região e pessoas interessadas pelo assunto), que ficou encarregado de se reunir e estabelecer um conjunto de reivindicações para a zona industrial. A reunião desse grupo de trabalho ocorreu em 30 de abril de 2010.

Frente às discussões durante a audiência pública, as mesmas subsidiaram a reunião do grupo de trabalho que organizou um conjunto de reivindicações a serem cumpridas a curto e médio prazo, além das demais ações elencadas. 
Abaixo seguem as reivindicações de curto e médio prazo que apresentaremos

em forma de tabela:

Tabela 1: Reivindicações para a Zona Industrial

\begin{tabular}{|c|c|c|}
\hline $\begin{array}{l}C \\
U\end{array}$ & Duplicações & $\begin{array}{l}\text { - Avenida Paraná } \\
\text { - Avenida Victor Andrew } \\
\text { - Avenida Pereira da Fonseca } \\
\text { - Avenida Conde Zeppelin (continuidade) }\end{array}$ \\
\hline $\begin{array}{l}\text { R } \\
\mathbf{T} \\
\mathbf{O}\end{array}$ & Pavimentações & $\begin{array}{l}\text { - Avenida Jonh Boyd Dunlop } \\
\text { - Rua Prof. João Franco De Almeida Filho (Travessa da Av. Conde Zeppelin) } \\
\text { - Rua Ernesto Robim (Travessa da Av. Conde Zeppelin) } \\
\text { - Ruas da vila Iporanga }\end{array}$ \\
\hline & Parque Municipal & - Estação de Tratamento de Água do Éden (ETA Éden) \\
\hline & Escola & - Escola SESI Zona Industrial \\
\hline $\begin{array}{l}\mathbf{P} \\
\mathbf{R}\end{array}$ & Recuperação & - Avenida Independência \\
\hline $\begin{array}{l}\text { A } \\
Z \\
0\end{array}$ & Melhorias nos serviços & $\begin{array}{l}\text { - Fornecimento de energia elétrica (quedas constantes de energia) } \\
\text { - Iluminação pública das ruas: Ernesto Robim e João Franco de Almeida Filho } \\
\text { - Fornecimento na transmissão de banda larga (Internet) }\end{array}$ \\
\hline $\begin{array}{l}\text { M } \\
\dot{E} \\
\text { D } \\
\text { I } \\
\text { O }\end{array}$ & Pavimentações & $\begin{array}{l}\text { - Avenida Georg Schaeffler } \\
\text { - Rua Moacir de Castro (travessa da Avenida Independência) } \\
\text { - Rua Eng. Carlos Okretic (travessa da Avenida Independência) } \\
\text { - Rua Irineu Dias da Rosa (paralela a Avenida Paraná-Cajurú) } \\
\text { - Rua Lucídio Monteiro de Carvalho (travessa Avenida Paraná) } \\
\text { - Alargamento da Rua Domingos Silvestre (travessa da Av. Paraná) } \\
\text { - Estrada dos Ferraz } \\
\text { - Rua Seiki Murakami (Aparecidinha) } \\
\text { - Trecho Av. Liberdade, Paralela a Rodovia Castelinho Km 5,5 }\end{array}$ \\
\hline $\begin{array}{l}\text { P } \\
\text { R } \\
\text { A } \\
\text { Z } \\
\text { O }\end{array}$ & Implantação & $\begin{array}{l}\text { - Centro Esportivo do Éden } \\
\text { - Agência Bancária no Cajurú } \\
\text { - Escola Técnica Municipal, Estadual ou Federal } \\
\text { - Trevo Castelinho Ponte Hollingsworth (acesso) } \\
\text { - Iluminação pública da HGP Química } \\
\text { - Retorno em frente à Empresa Ina }\end{array}$ \\
\hline $\begin{array}{l}\text { D } \\
\text { E } \\
\text { M } \\
\text { A }\end{array}$ & Pavimentações & $\begin{array}{l}\text { - trecho da Rua Bonifácio De Oliveira Cassú (Av. Pirelli) (Éden) } \\
\text { - Rua Hercules Francisquini (Éden) } \\
\text { - Estrada do Laureano } \\
\text { - Trecho da Alameda Wyda (travessa da Av. Victor Andrew) } \\
\text { - Rua Daniel da Purificação Vitorino }\end{array}$ \\
\hline $\begin{array}{l}\mathbf{A} \\
\mathbf{C}\end{array}$ & Implantações & $\begin{array}{l}\text { - SENAI - Zona Industrial } \\
\text { - Unidade Pré Hospitalar para atender a Zona Industrial } \\
\text { - Duplicação Avenida GM }\end{array}$ \\
\hline $\begin{array}{l}\text { Õ } \\
E\end{array}$ & Melhorias nos serviços & $\begin{array}{l}\text { - Linha } 38 \text { Aparecidinha Via Éden } \\
\text { - Recuperação Avenida Vila Olímpica }\end{array}$ \\
\hline $\mathbf{s}$ & Outros & $\begin{array}{l}\text { - Plano Diretor - Zoneamento } \\
\text { - Extração de Água Irregular / Zona Industrial } \\
\text { - Preservar o entorno do manancial da ETAS do Éden impedindo a } \\
\text { implantação de loteamentos e indústrias }\end{array}$ \\
\hline
\end{tabular}

Fonte: Grupo de trabalho - "Reivindicações da Zona Industrial" (30/04/2010)

Elaboração: Michel Soares R. da Silva 
As reivindicações discutidas e relacionadas foram encaminhadas para o prefeito, a Câmara Municipal, as secretarias de Desenvolvimento Econômico, de Obras e Infraestruturas Urbanas, além do encaminhamento para deputados estaduais que representam a localidade.

O interesse que envolveu uma diversidade de agentes da sociedade nos parece ser compreensivo e direcionado a um único objetivo, promover melhorias na infraestrutura local. Carlos (1994) escreve que as indústrias tendem a aumentar ao máximo suas vantagens, utilizando a cidade privativamente como condição geral de produção. Portanto, a pretensão dos diversos agentes em participar do grupo e organizar ações que promovam melhorias, tende a atender não só as necessidades da população em determinados aspectos, mas visam prioritariamente atingir os objetivos de empresas que se utilizam das cidades e dos espaços à elas destinados para aumentar seus lucros.

Analisando as reivindicações relacionadas, observamos que muitas delas estão mais próximas em atender os anseios empresariais do que os da população, pois no discurso se propaga que ao se alavancar melhorias para as empresas locais a população se beneficiaria. Só não se explica como, de que forma, quando, ou seja, pode ser que a logo prazo possam ocorrer melhorias para a população só que a vida delas, no aqui agora, continua sem muitas perspectivas.

Em "A Produção do Espaço", Lefebvre escreve que o espaço da homogeneização não tem nada de homogêneo e completa que: "À sua maneira poliscópico e plural, ele contém e unifica de maneira constrangedora fragmentos ou elementos dispersos." 
O bairro do Éden não é homogêneo. Nele temos vários grupos sociais e interesses diversos convivendo cotidianamente, o que gera contradições, antagonismos, pois a prioridade quando se pensa em ações para essa localidade, quase sempre o que vemos são as ligadas a reprodução do capital, visando um maior lucro e poder. A homogeneização econômica se dá pela fragmentação e hierarquização dos espaços na localidade.

Considerando a relação de poder estabelecida entre as partes envolvidas, empresas, políticas e sociedade, ao nosso ver, mesmo que em alguns momentos haja a convergência de ideias, os interesses permanecem em conflito passando por ideologias diferentes, objetivos diferentes, promovendo assim uma heterogeneidade na constituição do espaço e os conflitos e contradições que nele surgem a cada momento.

\section{3- A divulgação de novos investimentos}

O contexto atual sorocabano, a constituição de um Parque Tecnológico anunciado em 2009, tem movimentado os agentes públicos do município, assim como o centro das atenções de investidores e da população local e da região. Na perspectiva de ampliação da reprodução do capital, geração de empregos e a expectativa de melhores condições para a população, resultariam, consequentemente, no crescimento econômico da cidade, ao menos no discurso é isso que se propaga e que enche de esperanças aos munícipes.

Frente aos elementos citados, as articulações políticas promoveram a possibilidade de investimentos que, a nosso ver, tendem a priorizar as 
infraestruturas que atenderão aos anseios de empresas, demonstrando as contradições existentes entre a lógica da reprodução capitalista e o bem estar da sociedade.

Em março de 2011, o prefeito $^{20}$ anunciou melhorias para os bairros do Éden, Cajurú e Aparecidinha, com investimentos em obras viárias orçados em $\mathrm{R} \$ 20$ milhões. Além das obras viárias também constaram, a construção de uma Unidade de Urgência e Emergência Hospitalar e uma creche, ambas com aprovação e verbas do Governo Federal. A princípio teríamos então investimentos diretos tanto para a modernização e ampliação do setor industrial, como para obras sociais ligadas a saúde e educação. Entretanto, como mostraremos abaixo, há uma diferenciação no volume de investimentos que pesam positivamente mais para o desenvolvimento do setor industrial, em detrimento ao que é aplicado na saúde e educação.

Entre as obras de melhorias no sistema viário, constavam a duplicação da Avenidas Victor Andrew ( $R$ \$ 11 milhões), Pereira da Fonseca ( $R \$ 1,45$ milhões) e Conde Zepelin ( $R$ \$ 2,25 milhões), justamente as que fazem parte das reivindicações dos empresários locais, bem como de moradores que se deslocam constantemente por essas vias . Ao que tudo indica, a apresentação da lista de ações de curto e médio prazo foi ao encontro das pretensões da própria municipalidade, reforçando e qualificando suas articulações políticas, a partir da necessidade em promover a interligação das vias de acesso já existentes com as vias que fazem parte do chamado "Sorocaba Total", um projeto em execução na cidade desde o primeiro semestre de 2010. Esse projeto, cujo valor orçado é de $\mathrm{R} \$ 180$ milhões, $50 \%$ será financiado pela

\footnotetext{
${ }^{20}$ Fonte: Jornal Cruzeiro do Sul, caderno A, p.6 - 23/03/2011
} 
Corporação Andina de Fomento (CAF), para a construção dos Complexos Viários, André Franco Montoro, Mário Covas e Ulysses Guimarães. Sua construção contará com obras de duplicação, implantação e revitalização de ruas e avenidas, implantação de ciclovias e construção de ponte, para interligar a Zona Industrial e a Rodovia José Ermírio de Moares à Zona Norte, que inclui nessa área o Parque Tecnológico de Sorocaba, além de desviar o fluxo de veículos que circulam próximos às áreas centrais da cidade.

No final do mês de maio (2011), outras obras são amplamente divulgadas na mídia local (rádio, televisão e jornais), e com a presença do Governador do Estado de São Paulo na cidade. Em seu discurso o Governador Geraldo Alckmin anuncia que os recursos para as obras são provenientes do governo do estado e estão orçadas em $\mathrm{R} \$ 115$ milhões, sendo destinado ao recapeamento de $6,4 \mathrm{~km}$ da Avenida Independência (trecho duplicado) e da duplicação de 23,1 km da Avenida Paraná, ambas fazendo parte da SP-79 que liga as cidades de Sorocaba e Itu, além de acesso à Rodovia Castelo Branco que liga a capital paulista ao interior do Estado. Também foi anunciado que o processo de licitação tem prazo previsto para julho de 2011 com possível início das obras após contratação da empresa que se consolidará, provavelmente, em outubro do mesmo ano.

Outros investimentos constaram na agenda de visita do governador. Entre eles a contratação de empresa especializada para elaborar projeto de duplicação da Rodovia João Leme dos Santos (SP-264) que liga as cidades de Sorocaba e Salto de Pirapora e acesso para o campus da Universidade Federal de São Carlos (UFSCAR). O Aeroporto de Sorocaba receberá investimento de $R \$ 750$ mil para ser empregado em infraestrutura, 
equipamentos de telecomunicação aeronáutica e monitoramento no entorno do aeroporto visando a segurança de pousos e decolagens de aeronaves. Além desse último investimento, foi divulgado obra de via paralela à Rodovia Castelo Branco o que viabilizará o acesso ao Parque Tecnológico de Sorocaba.

Confrontando as reivindicações para a zona industrial com os anúncios realizados por parte da prefeitura e do governo do estado, constatamos que os itens contemplados, em sua maior parte, atendem mais as pretensões das empresas locais e de um projeto de organização do espaço sorocabano em detrimento aos anseios da população que continuarão perpetuando e renovando suas cobranças aos agentes públicos locais.

O destino desses investimentos colocam em destaque obras que permitirão a melhoria na dinâmica do deslocamento, na circulação de mercadorias e pessoas pelas principais vias da cidade. Essas vias durante muitos anos se tornaram, de certa forma, obsoletas e reestruturá-las viabiliza uma nova perspectiva que inclui além da interligação entre a Zona Industrial e a Zona Norte, requalificar a região destinada as atividades produtivas servindo de atrativo para a implantação de novos empreendimentos. Em geral essas obras são anunciadas pela administração municipal como essenciais ou, como são propagadas na mídia, são de caráter emergencial. A questão que fica é: emergencial para quem?

Apenas as obras de construção de uma Unidade de Emergência e de uma creche são timidamente anunciadas a partir de aprovação do governo federal, podendo classificá-la como de maior importância para a população da Zona Industrial. Para quem vive no Éden essas obras ligadas a saúde e educação são essenciais, entretanto não servem apenas a população local., 
Também são utilizados por pessoas que circulam pela região, oriundos de outras partes da cidade que para a região do Éden se deslocam para exercerem suas atividades profissionais. Por exemplo, o local onde se pretende instalar a Unidade de Emergência será na Avenida Independência, em área próxima ao Posto Avançado do Corpo de Bombeiros inaugurado em 1999, para atender as ocorrências locais. Sendo assim, a Unidade de Emergência, complementará o atendimento de emergência à população.

Portanto, podemos concluir que muitas das infraestruturas que ao longo do tempo foram viabilizadas para a região, parecem estar vinculadas ao crescimento econômico da cidade, tornando necessário equipar a cidade para atender a demanda dos investimentos industriais em detrimento das necessidades locais, que aparecem nas prioridades da municipalidade como secundárias. No próximo capítulo, trataremos da tentativa de emancipação dos bairros do Éden e do Cajurú do Sul, que em parte justifica nossa discussão sobre as infraestruturas disponibilizadas no bairro durante o processo de desconcentração das indústrias da capital paulista em direção ao interior do Estado a partir da década de 1970 e a industrialização recente da cidade de Sorocaba. 


\section{3- A luta pela emancipação}

Ao final dos anos de 1980 e em especial início dos anos de 1990, os jornais sorocabanos noticiam com grande ênfase a possibilidade de emancipação de dois distritos da cidade, Éden e Cajurú do Sul. O que motivava esse projeto de emancipação era o descontentamento de parte da população que alegava o descaso por parte dos agentes políticos com relação a precariedade de serviços e investimentos em infraestrutura nos referidos bairros . Frente a essa insatisfação, algumas lideranças locais iniciam um processo de discussão buscando o desmembramento do município de Sorocaba. Surge então, o movimento Pró-emancipação dos bairros do Éden e Cajurú do Sul (PROEMEC), sob presidência do Sr. João Alves Ferreira. A imagem 1 a seguir nos mostra um dos documentos utilizado para divulgar a existência do grupo empenhado em lutar pelo desmembramento, bem como a relação de carências presentes nesses dois bairros as quais a administração pública encontrava dificuldades em solucionar.

Frente aos problemas indicados no documento, um conjunto de solicitações que eram, para os moradores, de maior importância naquele momento, ainda não haviam sido atendidas pelos agentes e eram elencadas no rol dos motivos para a emancipação. Esperava-se que com a emancipação mais recursos seriam destinados ao local e, com isto, talvez esses problemas pudessem ser resolvidos. 


\section{PROEMEC Pro Emancipação EDEN - CAJURU}

Mensagem n: 1

Fev $/ 90$

O ser humano nasce, respira, se alimenta, cresce, se torna adulto e busca a liberdade da tutela de seus pais.

Da mesma forma um povoado se desenvolve, cresce, torna-se vila, a seguir volta-se para uma forma organizada como distrito, e ao se tornar adulto transforma-se em cidade para ser livre.

POR QUE EMANCIPAR?

Voltando à história citamos o caso de nosso Brasil, onde D. Pedro I emancipou-o de Portugual. Dai em diante, nessa trajetória muitas emancipações ocorreram, buscando o progresso, desenvolvimento, melhores e dignas condições de vida para o povo.

No nosso caso, Éden e Cajuru, já existe um movimento constituido para torna-los municipios, pois a emancipação pretendida é um direito amplamente assegurado pelas constituição Federal e Estadual.

Referido movimento é oportuno para a emancipação no sentido de melhor administração das necessidades existentes, através dos recursos já gerados na própria localidade para aplicação nas seguintes áreas:

- Preservação do Meio Ambiente;

- Mais e melhor assistência médica e social;

- Mais e melhores escolas e pré-escolas;

- Mais saneamento básico;

- Mais segurança;

- Mais e adequadas iluminações públicas;

- Criação de áreas de lazer, esporte, cultura e recreação;

- Aperfeiçoamento no sistema de transporte coletivo;

- Abastecimento de gêneros alimentícios mais baratos e de ótima qualidade at ravés de unidades minicipais voltadas para este fim;

- Aperfeiçoamento no sistem de abastecimento de água;

- Criação de escolas profissionalizantes;

- Criação de Creches;

- Melhor direcionamento dos meios de produção: Indústria, Comércio e Agricultura.

Enfim, tudo o mais necessário para melhor qualidade de vida de nossa gente. da.....

Por último agradecemos a leitura da presente mensagem, junte-se a nós e conscientize-se

EMANCIPAÇÃO JÁ

E NO PLEBISCITO

VOTE SIM

Imagem 1: Documento destinado ao esclarecimento da população local

Entre os assuntos em pauta, temos como primeiro item a preservação

do meio ambiente. Naquele momento estava ocorrendo a extração de areia às 
margens do Rio Pirajibú, um dos afluentes do Rio Sorocaba e de grande importância para o abastecimento de água dos bairros da localidade. Na edição do Jornal Cruzeiro do Sul de 03/04/1991 ${ }^{21}$, passados um ano e dois meses após a elaboração do documento que demonstrava como um dos problemas, noticiou-se, nessa edição, que o Promotor de Justiça e Curador do Meio Ambiente, Sr. Marco Antônio Vargas Pereira, havia ajuizado ação civil pública para apurar os danos causados pela extração de areia do rio Pirajibú, no bairro do Éden. Sendo assim, os olhos dos emancipacionistas também estavam voltados às questões ligadas ao meio ambiente, já que afetava diretamente a vida cotidiana, por meio do abastecimento de água e não apenas as questões econômicas.

Podemos relacionar o item anterior ao do saneamento básico, em especial o abastecimento de água que apresentava falhas em seu fornecimento mesmo havendo disponibilidade represada no próprio bairro. $\mathrm{O}$ sistema de captação, tratamento e bombeamento não apresentava regularidade promovendo a falta de água em parte do dia e/ou dia, além do fornecimento apresentar-se em quantidade e pressão insuficientes para encher as caixas d'água das residências. Há de se considerar também que um dos problemas apontados sobre a extração de areia do rio, desvios em seu curso poderiam ter afetado o abastecimento do reservatório sendo que no período de estiagem o problema se agrava. Devemos alertar que isso não é novo. Esse problema surge na segunda metade da década de 1980, como foi apresentado anteriormente por meio da notícia do jornal local sobre o ajuizamento de ação civil pública de um Promotor de Justiça e Curador do Meio Ambiente.

\footnotetext{
${ }^{21}$ Jornal Cruzeiro do Sul, 03/04/1991- Caderno Cidade, p.06
} 
Como segunda necessidade apontada, a Assistência médica e social, tinha atendimento realizado por um Posto de Saúde com limitações de seus serviços. Algumas especialidades médicas como ortopedia, ginecologia e cardiologia tinham encaminhamento para outra parte da cidade, no caso a área central, o que demandava um deslocamento demorado e com dificuldade para chegar ao local indicado, no caso o Hospital da Santa Casa de Misericórdia de Sorocaba, bem como o Hospital Regional de Sorocaba. Há, até hoje, uma precariedade no meio de transporte coletivo, referente ao tempo de viagem das duas linhas de ônibus que circulam pelo bairro, a linha 53- Éden e a 31- Cajurú, com tempo médio de trinta minutos até a Santa Casa de Misericórdia. Caso a indicação fosse o Hospital Regional o tempo de deslocamento era mais demorado, pois necessitava de outras linhas de ônibus, podendo acrescentar, pelo menos mais vinte ou trinta minutos, entre a espera pela condução e a chegada ao local. Como o hospital também realiza atendimento de outras localidades, o tempo de espera chegava a ser em média entre uma e duas horas dependendo do horário, sem contar o tempo para a realização de exames.

A terceira solicitação refere-se às escolas e pré-escolas, que apresentavam números insuficientes de vagas para atender a população, em especial para o segundo grau, atualmente ensino médio, e pré-escola. No caso do ensino médio, a Escola Estadual Professor Francisco Coccaro, a mais antiga do bairro, passou a oferecer o ensino médio a partir do ano de $1986 \mathrm{com}$ apenas duas salas do primeiro ano no período noturno, conforme informação obtida junto à secretaria da própria escola. $\quad$ O gráfico 1 a seguir mostra a evolução de matrículas realizadas entre 1980 e 1991. 
Gráfico 1: Número de matrículas efetuadas na escola estadual

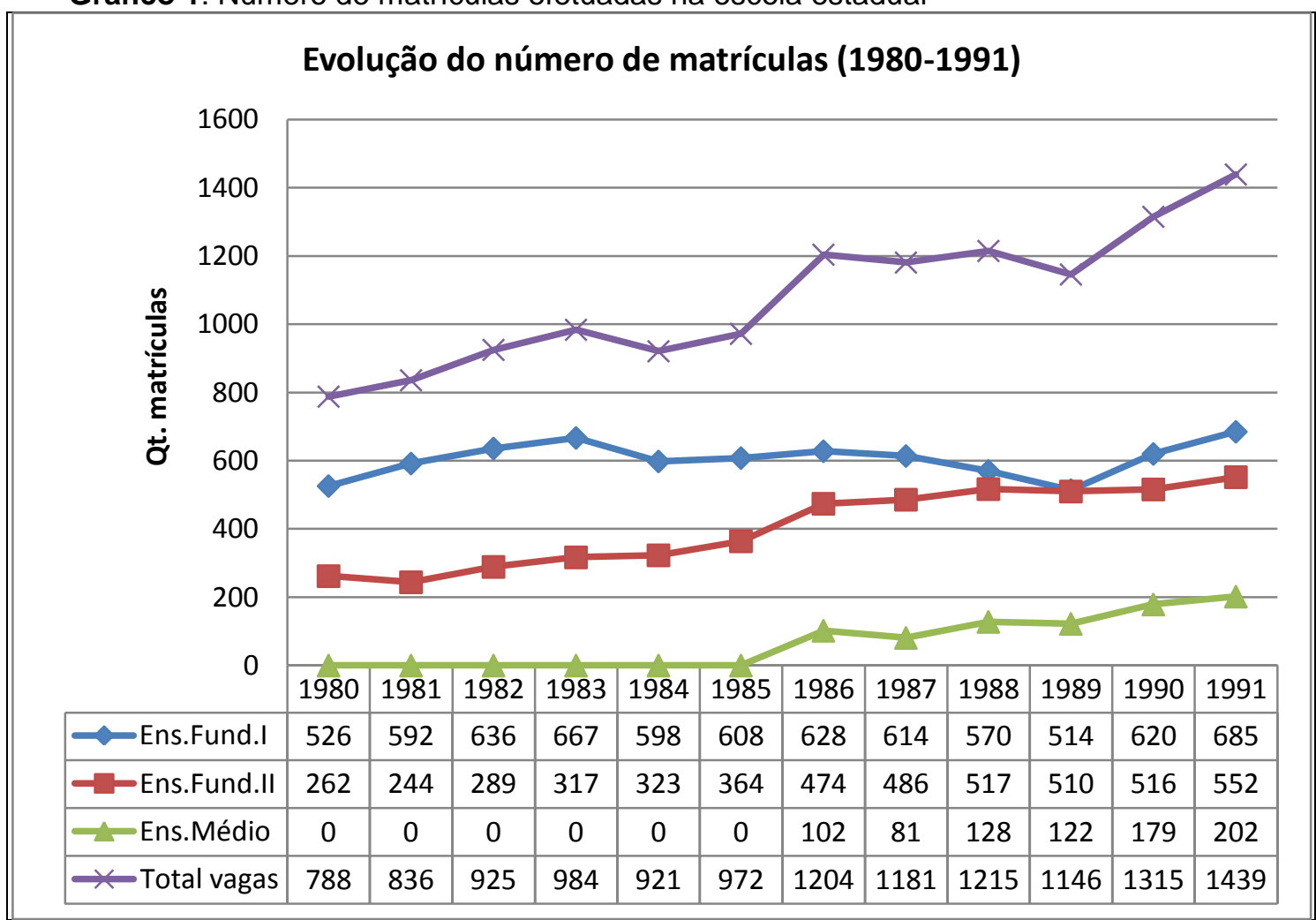

Fonte: Registros disponíveis na secretaria da escola local

Elaboração: Michel Soares R. da Silva

Para explicar e justificar a necessidade da criação de vagas nesse período realizamos uma pesquisa com base nos resultados da escola entre os anos de 1980 e 1991. Confrontamos com dados dos censos de 1980 e 1991, por grupos de idade, para justificar o que se requisitava.

O grupo selecionado foi entre 5 e 9 anos, o primeiro por considerarmos ser o mais próximo ao ensino fundamental I. O segundo entre 10 e 14 anos, se aproxima ao ensino fundamental II e finalmente o terceiro grupo entre 15 e 19 anos referente ao ensino médio. Também poderíamos levar em consideração um quarto grupo, 20 a 24 anos, pois naquele momento era comum um elevado número na evasão escolar, visto que, em alguns casos, retornavam aos estudos tanto para o fundamental II quanto para o ensino médio. 
Analisando esses três grupos de idade (Tabela 1) e confrontando com a quantidade de matrículas, notamos que havia uma demanda que não supria a necessidade local.

Tabela 1 : Grupo de Idade

\begin{tabular}{|c|c|c|}
\hline IDADE & 1980 & 1991 \\
\hline $00-04$ & 765 & 1121 \\
\hline $05-09$ & 674 & 1310 \\
\hline $10-14$ & 632 & 1269 \\
\hline $15-19$ & 584 & 1127 \\
\hline $20-24$ & 504 & 1034 \\
\hline $25-29$ & 494 & 907 \\
\hline $30-34$ & 410 & 885 \\
\hline $35-39$ & 301 & 790 \\
\hline $40-44$ & 252 & 686 \\
\hline $45-49$ & 166 & 461 \\
\hline $50-54$ & 180 & 326 \\
\hline $55-59$ & 130 & 241 \\
\hline $60-64$ & 109 & 192 \\
\hline $65-69$ & 83 & 131 \\
\hline $70(+)$ & 97 & 175 \\
\hline IGNOR. & 2 & 0 \\
\hline
\end{tabular}

Fonte: IBGE

Elaboração: Michel Soares R. da Silva

Tabela 2: Déficit de vagas por faixa etária (1991)

\begin{tabular}{|c|c|c|c|}
\hline Faixa etária & Total de pessoas & Número de matrículas & Déficit de vagas \\
\hline 5 a 9 anos & 1310 & 685 & 325 \\
\hline 10 a 14 anos & 1269 & 552 & 717 \\
\hline 15 a 19 anos & 1127 & 202 & 925 \\
\hline Total & 3706 & 1439 & 1967 \\
\hline
\end{tabular}

Fonte: IBGE e secretaria da escola local

Elaboração: Michel Soares R. da Silva 
Ao analisar o primeiro grupo de idade (5 a 9 anos), o número de matrículas que era de 685 em 1991, os números do IBGE indicavam para essa faixa etária uma quantidade de 1310 pessoas. Portanto, para esse ano havia um déficit de 325 vagas, considerando as matrículas de crianças entre 5 e 6 anos na educação infantil com vagas na escola da prefeitura (Centro de Educação Infantil - CEI), que ficava em torno de 300 matrículas. Quanto às crianças de 10 anos que deveriam ser matriculadas na última série do fundamental I, a possibilidade em obter informações necessitaria de maior detalhamento, não é nossa pretensão aprofundar esse quesito.

Para o segundo grupo de idade (10 a 14 anos), enquanto as matrículas eram de 552, o IBGE apresentava um número de 1269 pessoas para essa faixa etária. E, finalmente para o grupo entre 15 e 19 anos, o número de matrículas era de 202, enquanto que os números do IBGE apontam para essa faixa etária a quantidade de 1127 pessoas.

Por meio dessa análise concluímos que a oferta de vagas se apresentava menor diante da necessidade real em atender a população local, em especial o ensino médio e a impossibilidade de cursos profissionalizantes. Temos que considerar também que a procura por escolas em áreas próximas ao centro da cidade far-se-ia em função, além do ensino médio os cursos técnicos profissionalizantes oferecidos como o mecânico, elétrico, processamento de dados, contabilidade, entre outros, importantes para a capacitação de jovens e adultos. Sendo assim, a preocupação em solicitar cursos profissionalizantes fundamentais para suprir as necessidades das empresas locais e a criação de creches para atender as famílias fica fundamentada por meio dessas informações. 
Portanto, parte da população tinha que se deslocar para outras escolas da cidade para continuar seus estudos, necessitava de um sistema de transporte eficiente que facilitaria a locomoção entre o centro da cidade e 0 bairro.

Devido ao transporte coletivo se apresentar deficiente naquele momento, contando com superlotação, intervalos irregulares entre os horários de circulação, com tempo de espera entre vinte e cinco e trinta minutos, dificultava a expectativa em ampliar os estudos. No período noturno, por exemplo, o último ônibus que tinha destino ao bairro era às 23 horas e 20 minutos, atendendo um grande número de pessoas, entre elas trabalhadores e estudantes. Caso ocorresse algum atraso por parte de alguma pessoa, sua alternativa era deslocar-se de taxi, um serviço extremamente caro quando havia aceitação por parte do taxista ou se deslocar a pé aproximadamente 15 $\mathrm{Km}$. Sendo assim, estudar nas escolas próximas ao centro da cidade diminuía seu tempo de deslocamento durante o período diurno e à noite o risco em perder o transporte coletivo e promover alternativas anteriormente citadas gerava custo ou maior demora no deslocamento após um dia extenuante de trabalho e estudos. Outro item destacado pelos moradores é relativo a questão da segurança, ou na visão de muitos da violência urbana. Segundo relato de alguns moradores, o assalto ao Banco Bradesco instalado há pouco tempo ( no caso anos 80 ) e o homicídio cruel de um vigia noturno com golpes de enxada em uma loja de material de construção, ambos ocorridos na segunda metade da década de 1980, deixou a população local muito preocupada e com sentimento de insegurança. Como o bairro fica próximo das Rodovias Castello Branco e José Ermírio de Moraes, suas ruas se tornam rotas propicias para 
fuga de bandidos. Nesse período (final da década de 1980), a instalação de uma unidade da polícia militar, o 6ํㅡㄹ Distrito Policial, foi considerada insuficiente para atender as ocorrências dos bairros do Éden, Cajurú do Sul, Aparecidinha e áreas próximas, operando com apenas uma viatura, além de seu funcionamento ter horário limitado entre as 8 horas e 18 horas de segunda a sextas-feiras.

Quanto à iluminação pública, o bairro crescia e a precariedade aumentava à medida que novos loteamentos eram disponibilizados, sendo que o serviço demorava a ser fornecido. Além disso, mesmo quando instalada a iluminação era de qualidade inferior, com postes de madeira e lâmpadas incandescentes que facilmente tinham problemas em seu funcionamento. Para piorar a situação, essa iluminação era alvo fácil do vandalismo, pois não havia um sistema de proteção das lâmpadas.

Quanto à criação de estruturas que pudessem contemplar o lazer, o esporte, a cultura e a recreação, a atuação dos agentes públicos deixava a desejar, pois o que se disponibilizava no bairro era apenas a construção de pequenas praças contendo gramado, alguns bancos e iluminação. Apenas uma das praças, a maior entre as três ou quatro existentes na época, disponibilizava uma quadra de esporte onde se praticava futebol ou vôlei, cujo material utilizado na construção de seu piso é o mesmo que se usa para a pavimentação de ruas e estradas. Por ser praticamente o único espaço para a prática de atividades esportivas pelas crianças e adolescentes aos finais de semana, a disputa na ocupação daquele espaço era grande gerando desentendimentos entre os interessados. Momentos que promovessem eventos culturais eram inexistentes. Na recreação apenas uma vez por ano, 
período de recesso escolar (mês de julho), havia um projeto promovido pela prefeitura, chamado "Férias Quentes". Esse evento acontecia na escola pública local durante uma semana com a participação de monitores voluntários da própria comunidade e atendia crianças na faixa etária entre 6 e 10 anos contendo atividades como, leitura, teatro, desenho, dança, música, atividade física, entre outras.

No sistema de transporte coletivo, o Éden não era o único bairro com os problemas na prestação desse serviço, outros bairros também esboçavam insatisfação, pois, naquela época o sistema de transporte estava se reformulando. Entre os itens da reformulação que ocorria havia a mudança na forma de prestação de serviço, que até então era realizada pela Viação Manchester (VIMA), com uma frota de veículos ultrapassados e serviço deficiente. A nova gestão na prestação do serviço, que ficou vinculada a URBES - Trânsito e Transportes ${ }^{22}$ gerou uma longa "batalha" judicial entre a empresa e a prefeitura. Outro item de mudança foi a construção de dois terminais de ônibus inaugurados de 1992, o Santo Antônio, estruturado em área pertencente à antiga Fábrica Santo Antônio ${ }^{23}$, próximo ao centro da cidade, e o São Paulo nas proximidades da Avenida Dom Aguirre (Marginal do Dom Aguirre), acesso ao terminal Rodoviário de Sorocaba e as Rodovias

\footnotetext{
${ }^{22}$ A Urbes - Trânsito e Transportes é uma empresa pública de direito privado, criada pela Lei Municipal $n^{\circ} 1.946$, de 22/02/78, sob a denominação "Companhia de Desenvolvimento de Sorocaba - CODESO" (alterada para a atual denominação, "Empresa de Desenvolvimento Urbano e Social de Sorocaba URBES", pela Lei $n^{\circ} 2.184$, de 28/12/82).

A Lei Municipal no 3.115, de 11/10/89, alterou as atribuições originais da Urbes - Trânsito e Transportes para que, no Município, passasse a organizar e prestar o serviço público de transporte coletivo de passageiros: planejar, controlar e fiscalizar os serviços de táxi, lotação, fretamento, transporte de escolares e transporte de cargas, implantar, gerenciar e explorar estacionamentos de veículos e estações terminais de passageiros em próprios da Prefeitura ou em vias públicas, executar serviços e obras no sistema viário, relacionados com suas atribuições, gerenciar o caixa único do Sistema de Transporte Público Coletivo e gerenciar o Fundo de Prevenção e Melhoria do Transporte Coletivo - FMT.

${ }^{23}$ Importante fábrica têxtil de Sorocaba, inaugurada em 1913, auxiliando no processo de industrialização da cidade. Essa fábrica, junto com outras do grupo CIANÊ (Companhia Nacional de Estamparia), conhece seu declínio nos anos de 1980 e posteriormente o encerramento de suas atividades.
} 
Raposo Tavares e José Ermírio de Moraes. O mapa 1 apresentado no capítulo "O bairro do Éden e as indústrias" indica a localização dos atuais terminais construídos na época. Portanto, a insatisfação aumenta devido o serviço ainda se apresentar precário, algo facilmente constatado nos noticiários dos jornais locais sobre as mudanças no sistema de transportes e as críticas da população sorocabana. As reclamações da população eram procedentes, pois ocorria atraso nos horários, quebra de veículos no itinerário e tarifas elevadas pelo serviço. Estas eram algumas das reclamações mais contundentes e que justificavam a insatisfação da população, não só dos moradores do Éden, Cajurú e Aparecidinha, mas de outros moradores de Sorocaba.

O relato dos problemas mencionados promoveu, além da insatisfação, o aumento de pessoas a favor da emancipação que, a cada momento, estava se fortalecendo motivando a constituição de um grupo emancipacionista. Além disso, a Lei № 1210, de 27 de dezembro de 1963 previa, que a arrecadação oriunda do próprio distrito, a importância superior a 50\%, obrigatoriamente deveria promover melhoramentos públicos, o que parecia não ocorrer naquele momento.

Os jornais locais, já em 1985, informavam sobre os fatos estampando em suas páginas reportagens que demonstravam os problemas do bairro e toda a movimentação em torno da pretendida emancipação. (Imagens 2 e 3) 


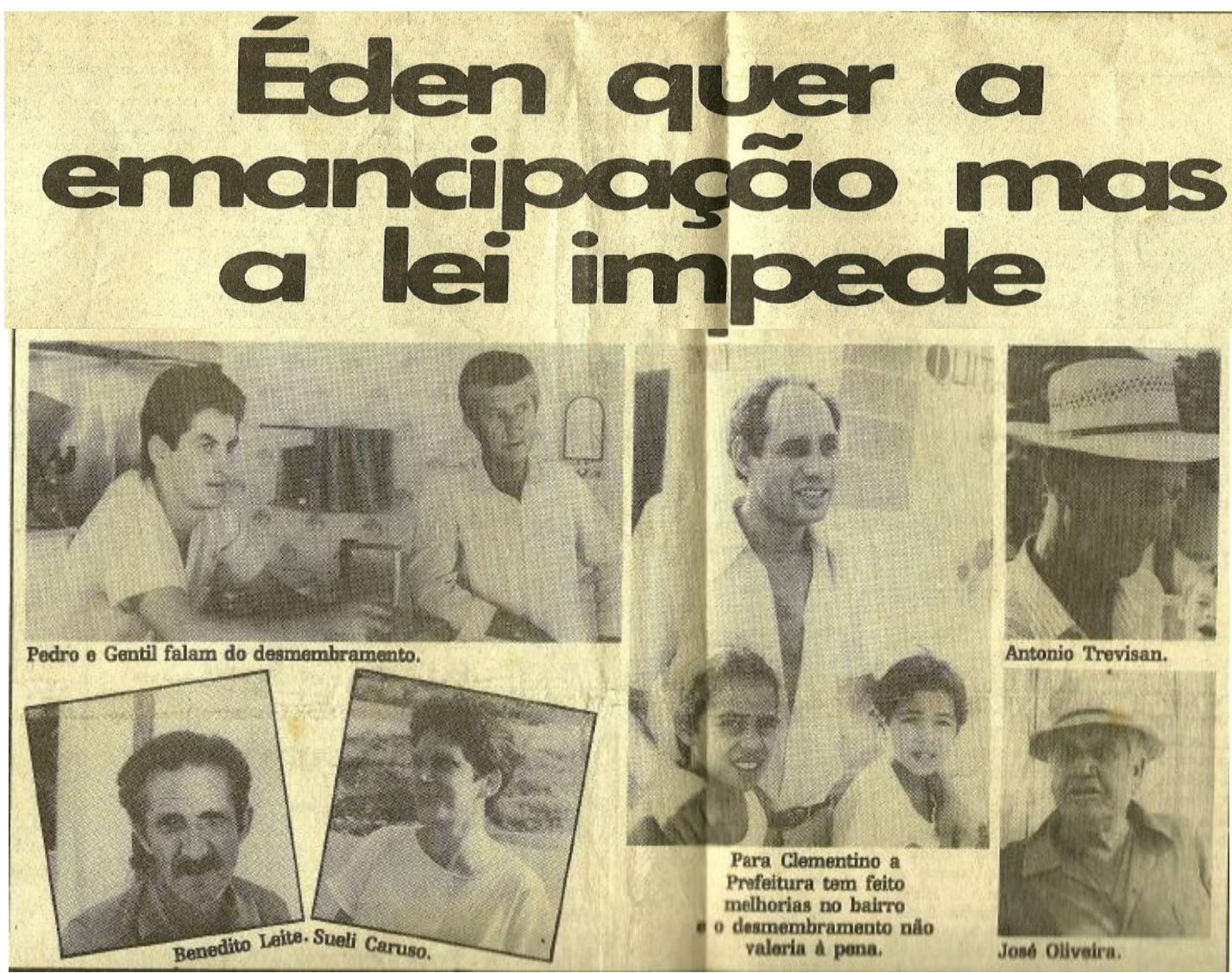

Imagem 2: Jornal Cruzeiro do Sul de 10/04/1985- Caderno: Local pág. 14

\section{Reunião no Éden acaba em nada}

\section{Depois dos discursos houve vaias, ofensas e confusão}

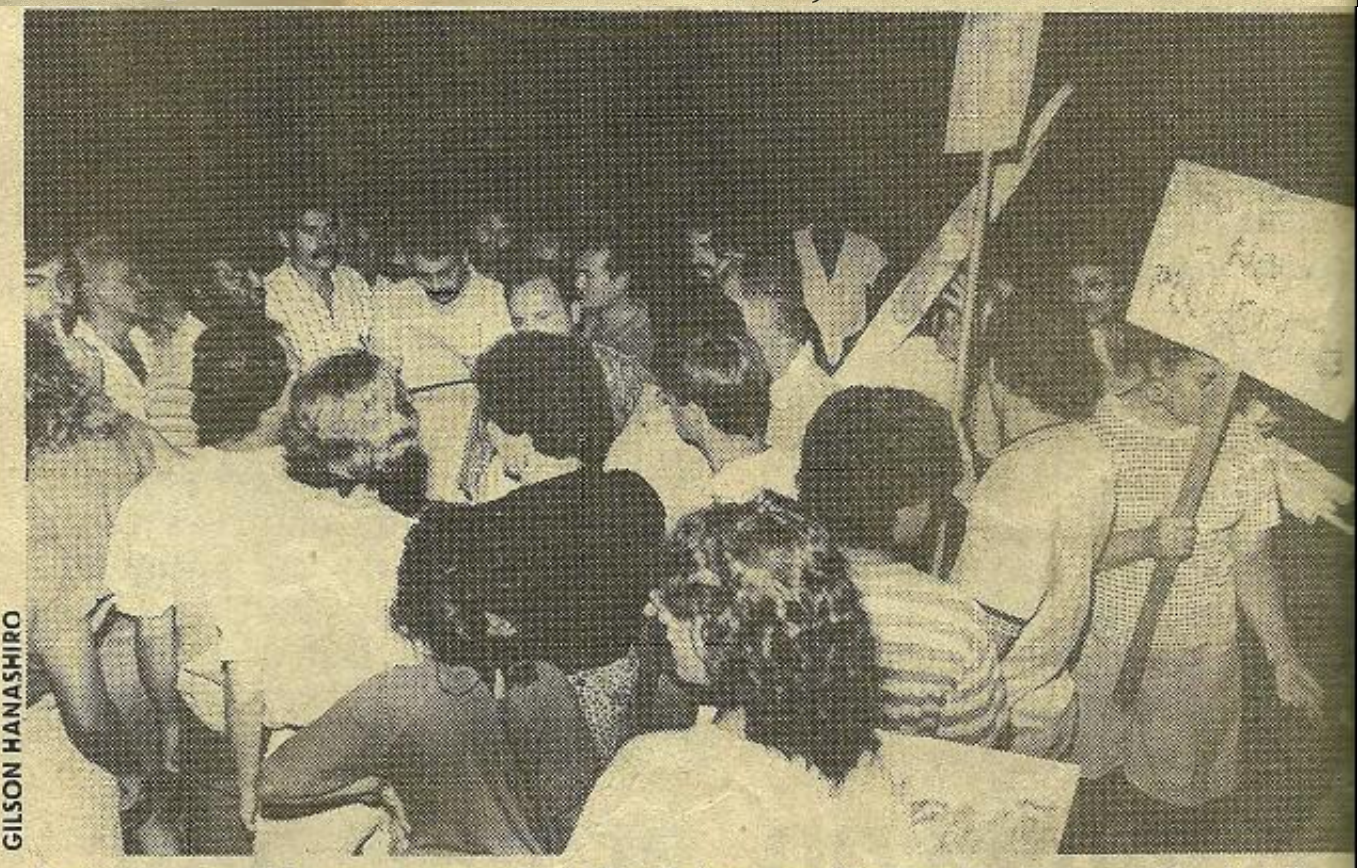

Após a reunião os emancipacionistas continuaram a manifestação. Imagem 3: Jornal Cruzeiro do Sul de 10/02/1990 
Para iniciar o processo de emancipação dos bairros, uma série de encontros da Sociedade Amigos de Bairro do Éden (SAB), membros do movimento Pró-emancipação dos bairros do Éden e Cajurú do Sul (PROEMEC) e a população local interessada pelo assunto, se reuniam para discutir as possibilidades da emancipação, traçar estratégias e manter informada a população.

Nas primeiras movimentações do grupo, que culminaram no documento informativo para a população (Imagem 1), cinco moradores estiveram no gabinete do Paço Municipal e, pelo que foi noticiado, manifestaram-se contrários à emancipação e o prefeito da época reconheceu esses moradores como "os verdadeiros líderes locais". Além disso, o prefeito comprometeu-se, com os cinco moradores, em realizar uma reunião no bairro para esclarecimentos sobre o assunto em questão. Abaixo, imagem do panfleto convocando os interessados em participar da reunião. (Imagem 4)

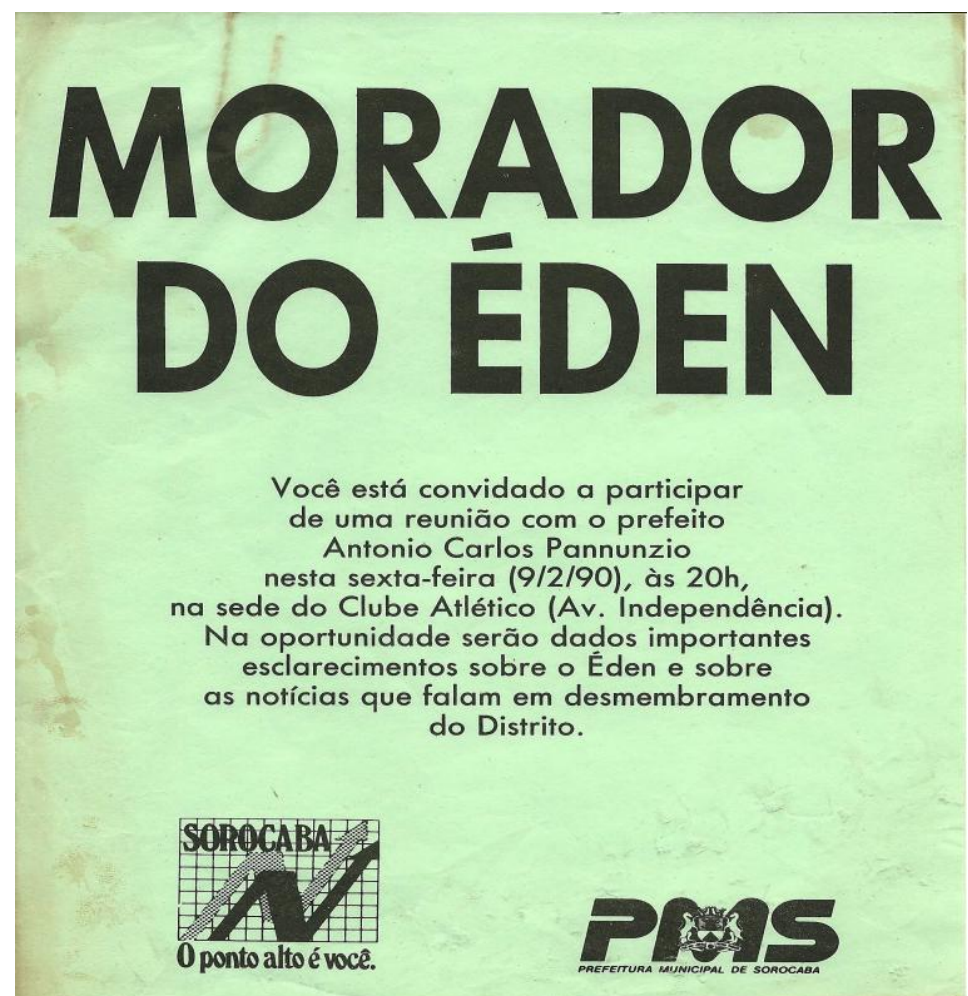

Imagem 4: Comunicado distribuído para participação da população local 
A reunião sobre a emancipação dos bairros do Éden e Cajurú não obteve sucesso, sendo suspensa. O motivo da suspensão se deu, pois 0 prefeito se retirou da reunião depois de ser vaiado pelos manifestantes presentes. O que motivou os protestos e em seguida a suspensão da reunião foi que esse político local, em uma tentativa de desqualificar as reivindicações populares, afirmou que "o movimento pró-emancipação estaria sendo realizado por "forasteiros", pessoas mal intencionados, agindo meramente por interesses políticos".

Como entender os motivos pelos quais conduziram tal discussão da emancipação do bairro e os desafetos constituídos? De acordo com alguns dados levantados em jornais da época sobre as mudanças na legislação estadual e municipal que tratava sobre a emancipação de municípios, entrevistas com moradores e, levando-se em conta o contexto da época (tratava-se de ano eleitoral), o movimento torna-se relevante e oportuno, tanto para moradores quanto para o município. Naquele momento, as mudanças nas leis estaduais facilitaria a formação de outro município, entretanto, segundo a Lei Orgânica Municipal (LOM) promulgada em 05 de abril de 1990, conforme o artigo 187 "tornaria extintos os Distritos do Município", o que ocasionaria maior dificuldade para o desmembramento.

A preocupação com esse artigo da Lei Orgânica Municipal era que o distrito tinha certa autonomia e ao tornar-se bairro, essa autonomia era suprimida, acarretando na impossibilidade do processo de emancipação. Como os emancipacionistas e parte da população local acreditavam que o desmembramento de Sorocaba era uma solução para minimizar os problemas apresentados nos distritos, o artigo os condicionaria como bairros e assim 
continuariam subordinados as decisões e aos interesses da administração municipal, ou seja, Éden e Cajurú continuariam fazendo parte da Zona Industrial de Sorocaba, tendo seu crescimento econômico articulado às necessidades de reprodução do sistema capitalista, que, na maior parte dos casos, não privilegia as questões sociais.

Frente a esse quadro, o conhecimento, por parte dos emancipacionistas, de uma nova lei que tramitava na Assembléia Legislativa, poderia dar o aval necessário, abrindo uma brecha legal, para que os distritos se tornassem municípios. Nesse mesmo ano a Lei complementar do Estado de São Paulo ํo 651 de julho de 1990, foi sancionada durante o governo de Orestes Quércia, cujo conteúdo desse documento continha orientações as quais muitos acreditavam ser de suma importância para promover a emancipação ou selar definitivamente tal pretensão.

Entre as orientações contidas nos artigos da referida lei, discutia-se muito sobre alguns deles como o Artigo 13 dizendo que: "A criação $e$ supressão de Distrito e suas alterações territoriais far-se-ão anualmente através de lei municipal, garantida a participação popular". Esse artigo dava respaldo necessário para que o município suprimisse o distrito, tornando-o um bairro comum como outros que compõem a cidade. Como já havia previsto na Lei Orgânica a supressão de distritos por parte do município, a Lei Complementar oferece maior sustentação aos argumentos do poder público municipal.

Mesmo com os argumentos anteriormente citados, os habitantes que faziam parte do movimento aspirando pela autonomia do distrito, esperançosos, buscavam orientações e apoio, de vereadores da cidade e do 
Deputado Estadual Tonca Falseti. Os artigos $1^{\circ}$ e $2^{\circ}$ da lei estadual parecia uma alternativa favorável aos emancipacionistas. Entre eles estavam:

Artigo 1. - A criação de Município far-se-á por lei estadual, precedida de consulta plebiscitária.

$\S 1$. - O processo de criação de Município terá início mediante representação assinada, no mínimo, por 100 (cem) eleitores domiciliados na área que se deseja emancipar, encaminhada a um Deputado Estadual ou diretamente à Mesa de Assembléia Legislativa.

$\S 3 .^{\circ}$ - A consulta plebiscitária, realizada na área a ser emancipada, só será considerada favorável se obtiver a maioria dos votos válidos, tendo votado a maioria absoluta dos eleitores.

Artigo 2.․ - Previamente ao plebiscito mencionado no artigo anterior, são condições indispensáveis e cumulativas para a criação de Município:

I - ser Distrito há mais de 2 (dois) anos;

II - possuir em sua área territorial, no mínimo 1000 eleitores;

III - ter centro urbano constituído;

Por meio desses dispositivos legais acreditava-se que algumas das condições citadas atenderiam os anseios, pois um formulário (imagem 5) contendo as assinaturas para serem enviadas à Assembléia Legislativa já circulava. Levantavam-se dados sobre o número de eleitores que, provavelmente, entre os quase 18.000 habitantes do Éden e Cajurú atingiria a quantidade exigida, além dos distritos terem sido constituídos há mais de 2 anos e com centro urbano constituído.

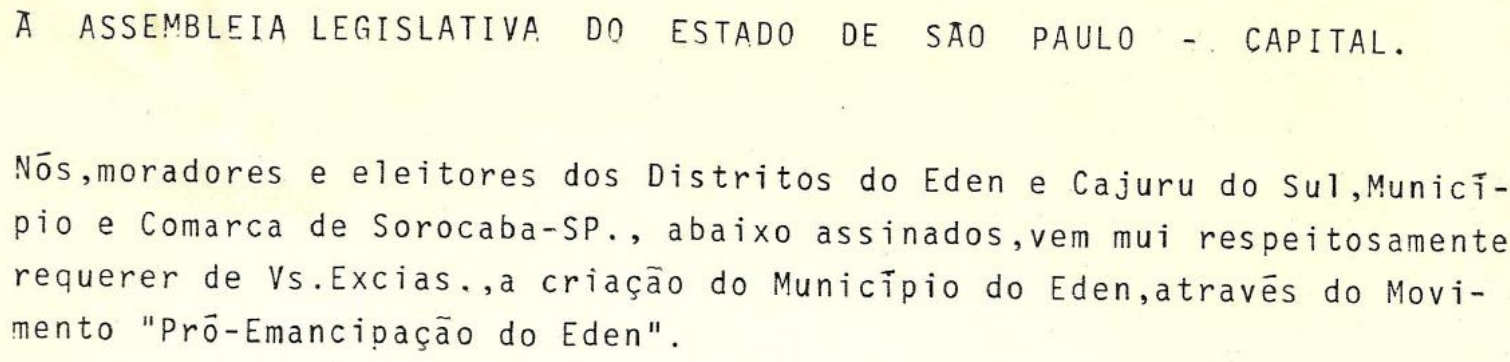

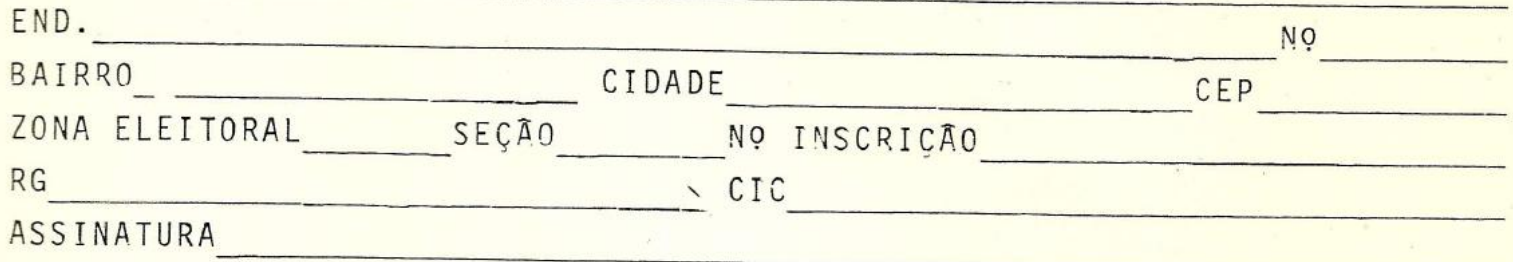

Imagem 5- Documento utilizado para coleta de assinaturas 
Como em 1985 o primeiro movimento que buscava reunir adeptos para a tentativa de emancipação não obteve o êxito desejado, as articulações de 1990 buscavam a melhor forma para não cometer equívocos que pudessem prejudicar uma nova tentativa, seguindo assim, as orientações previstas em lei e informando a população local sobre as etapas que poderiam culminar em seu desmembramento sob orientação do advogado Sr. Luiz Bosco Sardinha, na época considerado um dos poucos especialistas no assunto.

Naquele ano, no Estado de São Paulo havia em torno de 572 municípios, chegando aos atuais 645 já no ano de 1997 (gráfico 1).

Gráfico 1 - Evolução do número de municípios do Estado de São Paulo (1940 - 1997)

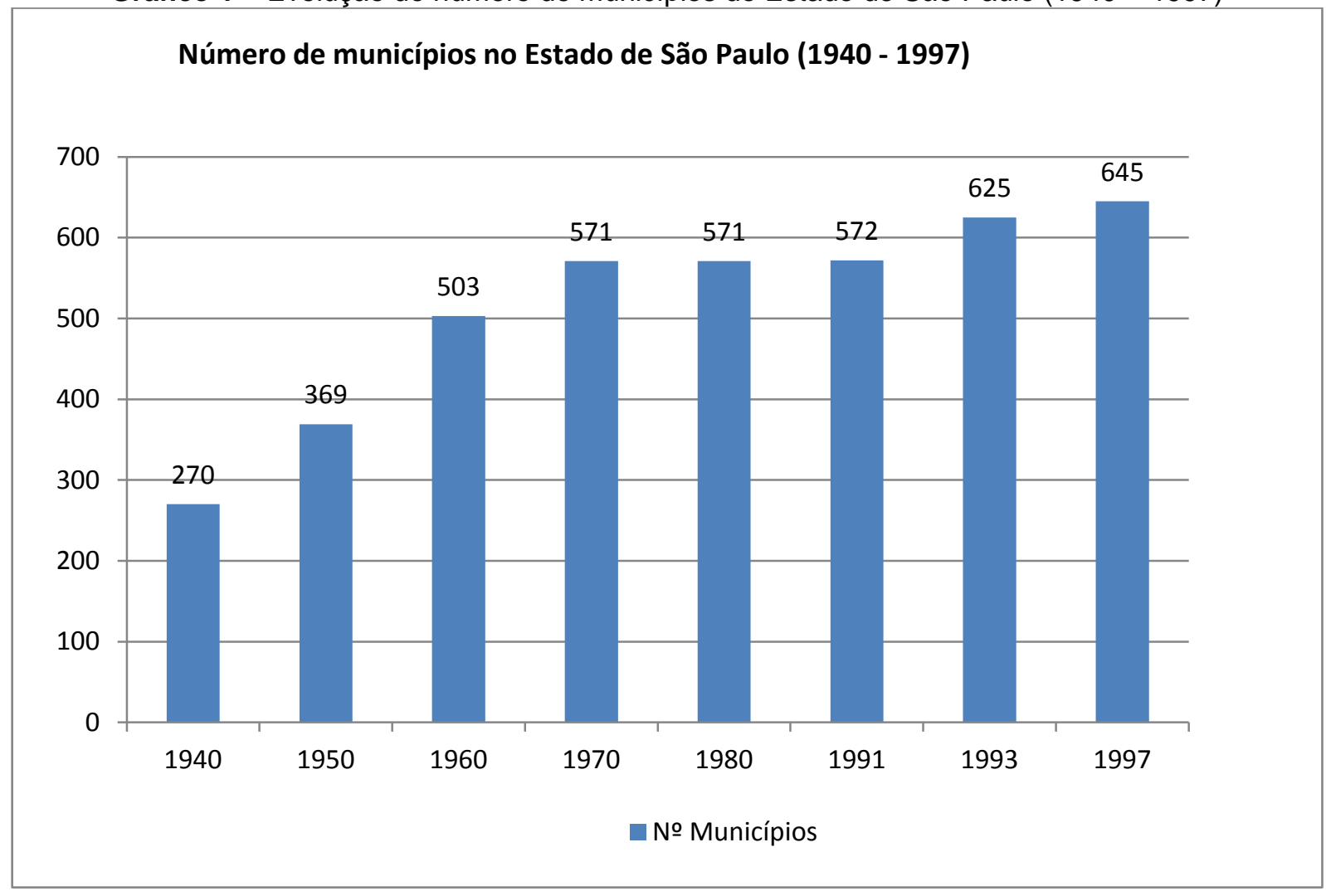

Fonte: IBGE 
O movimento pró-emancipação moveu ação na Justiça na tentativa de provar inconstitucionalidade do artigo 187 da Lei Orgânica Municipal que extinguia os Distritos do Éden e do Cajurú tornando-os bairros de Sorocaba. $\mathrm{Na}$ época o procurador- geral de Justiça do Estado de São Paulo, Dr. Antonio Araldo Ferraz Dall Pozzo, sinaliza um parecer favorável à inconstitucionalidade, baseado no fato de não ter havido a participação popular na decisão, um plebiscito.

Na eminência de uma possível emancipação, membros do movimento separatista e prefeitura divergem em opiniões cada um expressando seus interesses e seus motivos. Finalmente, o Instituto de Geografia e Cartografia (IGC), responsável pela análise do processo, elabora seu parecer (imagem 6) desfavorável ao desmembramento do Éden. Entre os cinco requisitos, dois foram os que impediram a emancipação. O primeiro apontamento foi por não apresentar distância mínima de três quilômetros entre o seu perímetro urbano e o município de origem e o segundo por interromper a continuidade do município de origem, bem como a preservação da continuidade históricocultural, ambas ligadas a proximidade das partes envolvidas.

Após a apresentação desse laudo enviado para apreciação da Assembléia Legislativa, os resultados não contribuíram para 0 encaminhamento desejado pelos membros do movimento emancipacionista. 


\section{Éden não cumpre requisitos para a emancipação}

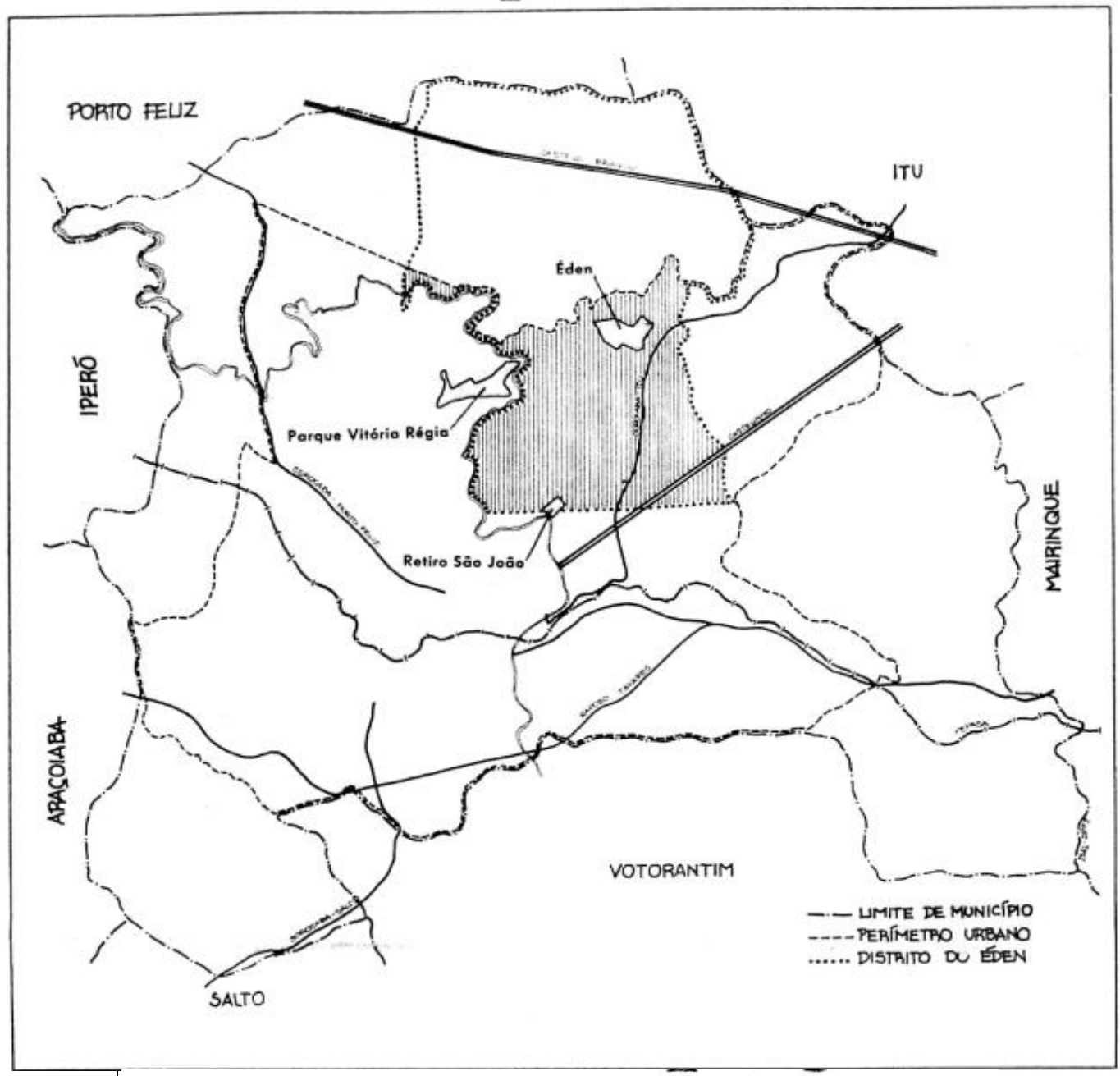

Dnis, dos cinco requisitos básicos para que um distrito possa se emancipar, de acordo com a lei comple. mentar estadual $\mathrm{n}^{\circ} 651$, de 31 de julho de 1990, não são cumpridos pelo Éden, segundo informou ontem o Instituto Geográfico e Cartográfico (IGC), órgão téc nico do Estado responsável pela análise desses requisitos. O relatório, elaborado pelo IGC, foi concluido e entregue à Assembléia Legislativa, "que deverá agora decidir os destinos do processo de emancipação, tomando como base o nosso relatório", comentou o diretor daquele instituto, José Henrique Zanella. De acordo com a análise, o Éden não apresenta "solução de continuidade de três quilô. metros no mínimo entre seu perimetro urbano, definido pelo competente órgāo téc. nico do Estado, e do município de origem" e năo cumpre o item que determina que o distrito "não deve in. terromper a continuidade territorial do município de origem, bem como preser. var a continuidade histórico-cultural do am biente urbano, ouvido o competente órgão técnico do Estado"'. O pedido de emancipação do Eden deve. rá ser examinado agora pe. los deputados, membros da Comissāo de Assuntos Municipais e, somente no caso de ser aprovado, é que irá a plenário. Caso não seja aprovado (por nảo cumprir os dois requisitos básicos da lei), a pretensão dos emancipacionistas do Éden, ficará frustrada.

Pág. 18

Imagem 6- Conclusão sobre o processo de emancipação Éden-Cajurú Fonte: Jornal Cruzeiro do Sul - 24/10/1990 
A partir desse laudo, há uma contestação sobre a real distância dos três quilômetros entre as duas "manchas urbanas" Éden-Sorocaba. Essa contestação gera noticiários polêmicos sobre o assunto nos jornais.

Segundo entrevista realizada no mês de abril de 2011, com um dos membros do movimento da época, este afirma que seu grupo chegou a pensar em solicitar a emancipação do Cajurú, o que aumentaria a distância em mais dos três quilômetros exigidos, o que provavelmente facilitaria a emancipação.

O Parque Vitória Régia (Sorocaba) foi o bairro utilizado para a medição da distância entre as "manchas urbanas" Éden-Sorocaba, sendo que dos 3000 metros necessários para a emancipação constatou-se apenas 2380 metros, restando outros 620 metros para a consolidação de mais um dos itens da lei em vigor na época. Sendo assim, solicitar a emancipação do Cajurú ampliaria em pelo menos mais cinco quilômetros em relação ao Éden e entre o Parque Vitória Régia e o Cajurú mais de sete quilômetros. Como a distância entre as duas manchas urbanas aumentaria as possibilidades para a emancipação alterava o contexto até então apresentado, seria necessário uma nova análise e um novo parecer técnico por parte o IGC. Ou seja, já não era mais o Éden que se emanciparia, mas um território que englobava os bairros do Éden e o do Cajurú. O mapa 2 ilustra as distâncias entre os pontos que se pretendia utilizar estrategicamente.

Outro ponto que desfavoreceu a separação era a preservação da continuidade histórico-cultural que era interrompida pela continuidade territorial do Retiro São João, que na época, foi considerada uma área de ocupação ilegal e, ao nosso ver, naquele momento, conveniente ao município a 
manutenção da situação de irregularidade para também justificar o que se estabelecia na lei estadual apresentada anteriormente.

Mapa 2 - Distância aproximada: ÉDEN- Vitória Régia / CAJURÚ- Vitória Régia

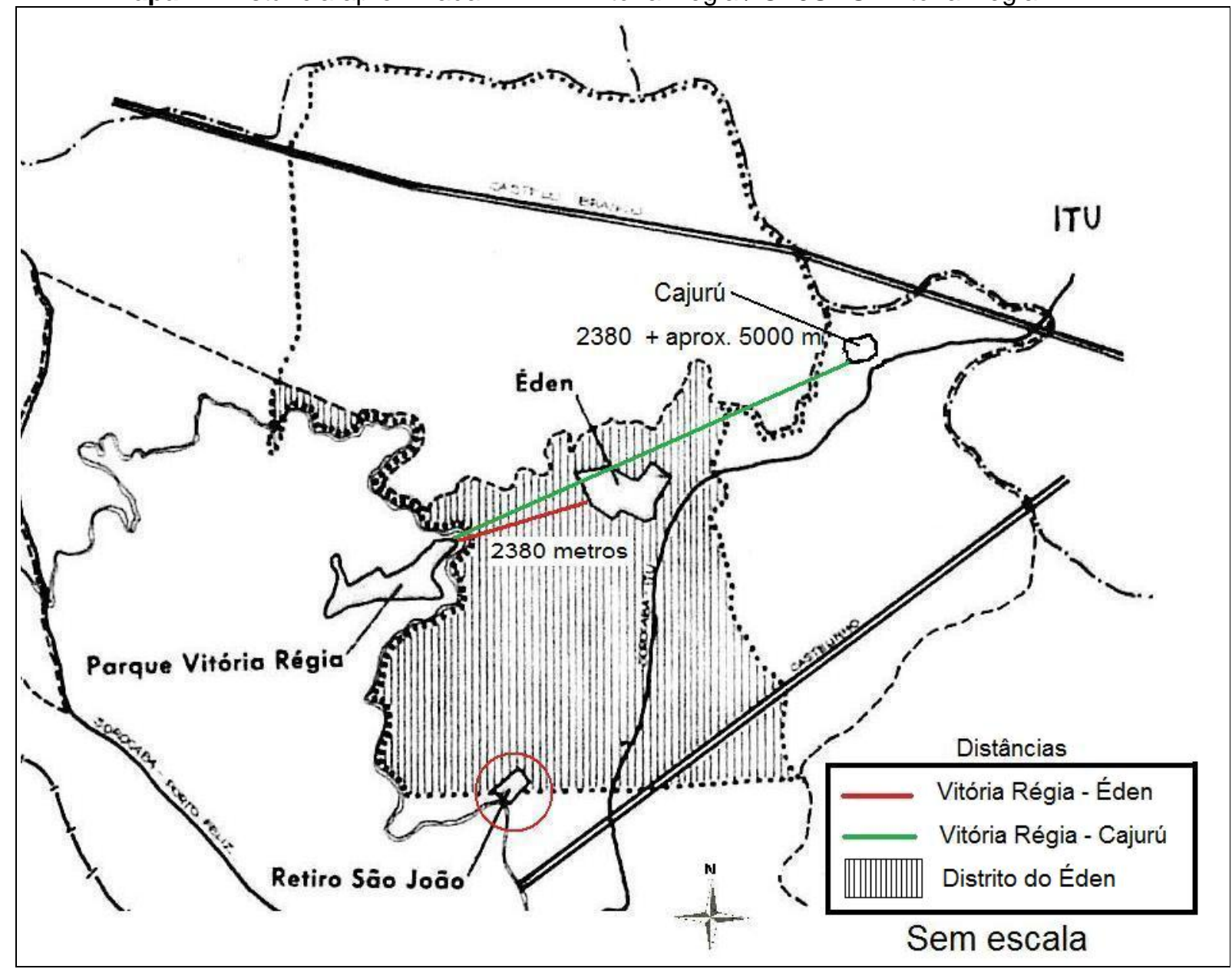

Adaptado de: Jornal Cruzeiro do Sul - 24/10/1990 Autor: Michel Soares R. da Silva

Pelo que percebemos, ao longo do processo de tentativa de emancipação, o desgaste do grupo formado foi inevitável e aos poucos enfraquecendo. A cada dia foi perdendo seu propósito, culminando na supressão do distrito e transformando-o em um bairro de Sorocaba, impossibilitando assim a sua emancipação.

É relevante destacar que, enquanto distritos subordinados ao município Sorocabano, Éden e Cajurú não tinham autonomia e sempre dependiam das 
ações dos agentes públicos em promover qualquer tipo de melhoria. $\mathrm{Na}$ condição de bairro haveria a mesma dependência, portanto, caso houvesse a emancipação, mesmo com as dificuldades enfrentadas, emergiriam novas possibilidades, novas condições, uma nova perspectiva. 


\section{4- Considerações Finais}

Movido pelo interesse em assuntos sobre a atividade produtiva, em especial a indústria, este trabalho visou compreender como o desenvolvimento industrial, que no senso comum se articula com melhorias sociais principalmente a partir da geração de empregos, afetou, em especial, as questões sociais existentes em Sorocaba e, em especial, nos bairros onde as indústrias se instalam. Com o movimento de desconcentração industrial da capital paulista em direção às cidades do interior do Estado que ocorreu a partir da década de 1970, foi o que contribuiu para que houvesse transformações significativas em diversas cidades, como é o caso de Sorocaba, que passaram a abrigar essas indústrias e, por conseguinte o que permitiu o desenvolvimento da presente pesquisa.

A cidade de Sorocaba tem seu processo de industrialização desde o final do século XIX, mas é a partir do processo de desconcentração industrial (meados século $\mathrm{XX}$ ) que há o boom industrial na cidade. Para garantir os investimentos industriais na cidade, muitas ações da municipalidade privilegiaram os interesses empresariais em detrimento das demandas da população. A partir dos anos 90 esse processo se intensifica.

Diante dessa nova realidade, foi necessário repensar a organização espacial da cidade dando origem a Zona Industrial sorocabana que providencialmente agregou três bairros, o Éden, o Cajurú do Sul e a Aparecidinha. O bairro do Éden foi o objeto principal de nosso estudo, por interesses particulares, mas também por polarizar maior atenção dos munícipes e apresentar maior população, além de congregar maior parte da 
infraestrutura necessária ao desenvolvimento industrial, em detrimento aos outros bairros que compõem a Zona Industrial. Não pretendemos dizer que um seja melhor que o outro e sim demonstrar que as diferenças poderiam ser menores, sabendo-se que, os bairros fazem parte do mesmo sistema de zoneamento.

A partir da criação desse zoneamento destinado a receber indústrias foi notório perceber pelas entrevistas, pesquisas em jornais, leituras e pela observação dos lugares, as mudanças proporcionadas no cotidiano da população local frente ao dinamismo que ora ocorreu, pelo menos, nos últimos 40 anos. Um exemplo foi a entrevista de um morador local, Rachid Mustafá, concedida ao Jornal Cruzeiro do Sul em 07/06/2004, que disse:

Meu pai tinha um armazém que abastecia 0 bairro. Naquela época, havia apenas dois horários de ônibus para o Éden, um pela manhã e um no final da tarde, quem não conseguia pegar esses coletivos, acabava indo a pé para a cidade, o que dava umas duas horas de caminhada. Às vezes, alguém parava para dar carona, o problema é que normalmente era caminhão de lenha e a gente se sujava todo.

O momento relatado era na década de 1960 e essa especificidade mostra que ao longo do tempo as transformações ocorreram, mesmo que, em momentos históricos distintos as necessidades se modifiquem. Portanto, pensar as transformações como algo isolado, não nos parece corresponder com a realidade. As mudanças ocorrem graças as intervenções dos agentes públicos e/ou privados, em geral associados. Essas ações de transformação espacial muitas vezes geram conflitos, principalmente quando não atendem as demandas e solicitações da população local.

Durante o desenvolvimento de nosso trabalho constatamos que as transformações no bairro ocorreram inerentes ao processo de reprodução do 
capital que demanda, por exemplo, da reorganização espacial utilizando-se do mesmo para cada vez mais obter o êxito pretendido, a reprodução do capital. Nesse caso a partir da atividade industrial.

Em nossas notas introdutórias buscamos caracterizar o contexto pelo qual o bairro do Éden estava inserido a partir da década de 1970, destacando alguns de seus aspectos como, a quantidade de população dos últimos 40 anos, o processo de constituição de um Plano Diretor que estabelece, entre as várias normatizações, a criação de uma Zona Industrial no município sorocabano que o inclui como parte integrante desse projeto. Como as estruturas oferecidas naquele momento se apresentavam insuficientes tanto para a população local quanto para a implantação de investimentos no setor industrial, mudanças ocorrem e, para compreender o processo pelo qual acontecia, desenvolvemos um capítulo que pudesse expressar a relação existente entre a dinâmica industrial de Sorocaba, frente ao processo de desconcentração industrial da capital paulista.

O capítulo em questão se fundamenta por meio de dados coletados do IBGE, da Fundação SEADE e do Município de Sorocaba que, ao serem analisados, mostram que essa dinâmica industrial local não ocorre isoladamente, relacionando-se com outras localidades. Essa dinâmica é percebida quando observamos o destino dos investimentos realizados, concentrando e privilegiando determinados tipos de atividades industriais, por exemplo, a automotiva, a de máquinas e equipamentos, material eletrônico, entre outras. Os investimentos em ampliação e implantação são os mais recorrentes, enquanto que os relacionados à modernização e em pesquisa e desenvolvimento tem menos investimento. Há de se destacar também que 
parte dos investimentos no setor industrial são provenientes de outros países, ou seja, as interferências externas são muito significativas, implicando em um determinado tipo de desenvolvimento produtivo.

Ao que tudo indica esse direcionamento concentrado nos investimentos em ampliação e implantação pretende atender a lógica capitalista e, junto a isso, se congrega uma indústria que atenda as demandas de mercado, uma indústria dentro dos princípios fordistas de produção.

No capítulo seguinte tratamos da análise do papel das indústrias presentes no bairro. Mesmo com as transformações que ao longo da história da cidade e do bairro foram realizadas, para a população local ainda há carências que se tornaram o mote para reivindicações emancipacionistas . As carências foram apresentadas por meio de uma lista de reivindicações para a Zona Industrial que possibilitariam, pelo menos na expectativa de parte da população local, melhorias significativas, caso fossem atendidas. Mas, o conjunto de reivindicações apresentado por parte de um grupo de trabalho composto por empresários locais e moradores, contribuíram em sua maior parte para a efetivação de projetos empresariais, postos em prática com a parceria do poder público. Sendo assim, concluímos que as ações públicoprivadas privilegiaram obras que colocassem em marcha os projetos de desenvolvimento industrial. De um lado, os empresários faziam propostas para melhorar o acesso e o entorno das empresas, visando ampliar seus negócios e do outro, os agentes públicos puderam "vender" a cidade a partir de uma imagem que sugere organização, com infraestruturas atrativas, proporcionando novos investimentos, principalmente industriais. 
Finalizamos nosso projeto com a análise da tentativa de emancipação do bairro do Éden, juntamente com outro bairro (o Cajurú) que compõem a Zona Industrial de Sorocaba. Nesse capítulo expusemos a insatisfação da população local entre o final da década de 1980 e o início de 1990, em parte demonstrando os motivos pelo qual surgem as reivindicações para a Zona Industrial, tratada no capítulo que o antecede.

As discussões que se desenrolam a partir da pretendida emancipação foram estimuladas pelo descaso da administração municipal, ao menos na visão de alguns dos moradores. A constituição de um grupo Pró-emancipação dos bairros do Éden e Cajurú do Sul (PROEMEC) que assumiu compromisso em defender os interesses locais e de todo o movimento de emancipação, está vinculada justamente ao suposto descaso que por vezes apresentamos durante o desenvolvimento do capítulo. O que se apresentou como elementos significativos e que motivou o processo de emancipação, foram as condições de vida que a população local vivia como, por exemplo, as deficiências no sistema de transporte, iluminação pública ausente ou precária, abastecimento de água irregular, atendimento médico precário, falta de vagas nas escolas públicas locais, entre outros.

Com base no contexto de um cenário de insatisfação articulado a brecha na lei estadual naquele momento, que permitia a emancipação, gerou expectativas em melhorar as condições locais, mesmo porque, com a arrecadação dos impostos das indústrias locais haveria, na concepção dos moradores que faziam parte do movimento emancipacionista, a possibilidade de promover as transformações sociais e infraestruturais pretendidas por parte da população local. 
Provavelmente, de acordo com as circunstâncias apresentadas naquele momento, a presença de indústria e a necessidade em melhorar a infraestrutura o bairro, seria algo positivo para os bairros do Éden e do Cajurú. Por outro lado, a cidade de Sorocaba que amargou na década de 1960 a emancipação do atual município de Votorantim, em hipótese alguma deixaria de articular situações que frustrassem a emancipação.

Concluímos então que, embora haja articulações de movimentos populares em promover transformações locais, as mudanças socioespaciais que prevalecem são as ligadas aos projetos de reprodução do capital. Para isso há uma relação de parceria entre os agentes públicos e privados atuando em várias escalas geográficas. A dinâmica posta no contexto atual, guardadas devidas proporções, envolvem articulações constantes entre o local e o global. 
Referências Bibliográficas

BAITZ, Ricardo. A implicação: Um novo sedimento a se explorar na Geografia? Boletim Paulista de Geografia, São Paulo, no84 - 2006.

BOTELHO, Adriano. Do fordismo à produção flexível: a produção do espaço num contexto de mudança das estratégias de acumulação do capital. São Paulo, 2000. 147 f. Dissertação (Mestrado em Geografia Humana) Faculdade de Filosofia, Letras e Ciências Humanas, Universidade São Paulo.

CARLOS, Ana Fani A . A cidade. 8aㅡ ed. São Paulo: Contexto, 2007. , Ana Fani A . Espaço e Indústria. 9ª ed. São Paulo: Contexto, 2001. , Ana Fani A. "São Paulo: do capital industrial ao capital financeiro" in CARLOS, Ana Fani A . e OLIVEIRA, Ariovaldo Umbelino (orgs).Geografias de São Paulo, vol 1 e vol 2. São Paulo: Contexto, 2004. Ana Fani A . O lugar no/do lugar. São Paulo: Hucitec, 1996.

CASTELLS. Manuel. A Sociedade em Rede - A era da informação: economia, sociedade e cultura, v.1. São Paulo: Terra e Paz, 1999.

CORRÊA, Roberto Lobato. Região e organização espacial. São Paulo: Ática, 1986.

GEORGE, Pierre. Geografia Industrial do Mundo. $7^{\text {a }}$ Ed. Rio de Janeiro: Bertrand Brasil, 2005.

HAESBAERT, Rogério. Blocos Internacionais de poder. 5a Ed. São Paulo: Contexto, 1996. 
HARVEY, David. Condição pós-moderna: uma pesquisa sobre as origens da mudança cultural. São Paulo: Edições Loyola, 2003.

LEFEBVRE, Henri. A Revolução Urbana. 3ª Ed. Belo Horizonte: UFMG. 2008. A Produção do Espaço (tradução do Núcleo de Geografia Urbana da UFMG) [s.d].

. La vida cotidiana en el mundo moderno. $3^{\text {a }}$ Ed. Madrid: Alianza Editorial, 1984.

. 0 direito à cidade. $5^{\mathrm{a}}$ Ed. São Paulo: Centáuro, 2008.

LENCIONI, Sandra. Reestruturação Urbana-Industrial no Estado de São Paulo: a região da Metrópole Desconcentrada. Espaço e Debates, São Paulo, № 38, p. 54-61, 1994.

PEREIRA NETO, Mario. Sorocaba Globalizada.Itu: Ottoni. 2005.

RIBEIRO. Emerson. Caminhos e descaminos: A ferrovia e a rodovia no bairro Barcelona em Sorocaba-SP- A produção espacial no proceso de industrialização e urbanização em Sorocaba. São Paulo, Annablume; Sorocaba: Prefeitura de Sorocaba, Linc, 2009.

SANTOS, Milton. e SILVEIRA, Maria Laura. O Brasil: Território e sociedade no início do século XXI. $2^{\mathrm{a}}$ ed. Rio de Janeiro: Record, 2001.

Metamorfoses do Espaço Habitado. $2^{\mathrm{a}}$ ed. São Paulo: Hucitec, 1991.

SEURB -Secretaria de Edificações e Urbanismo (SOROCABA-SP) PLANO DIRETOR - LEI № 8.181, DE 05 DE JUNHO DE 2007. (Revisão da Lei 7.122 de 04/6/2004) 
SILVA, Paulo Celso da. De novelo de linha a Manchester Paulista. Sorocaba: Projeto Linc, 2000.

SPÓSITO, Maria Encarnação Beltrão. Capitalismo e Urbanização. $7^{a}$ Ed. São Paulo: Contexto, 1996.

WERNECK, Braulio (Org). Almanach ilustrado de Sorocaba, 1914: repositório histórico, literário e recreativo, com ilustrações. Sorocaba: FacSimilar, 2006.

Prefeitura Municipal de Sorocaba. Termo de Referência do Parque Tecnológico Incentivado de Sorocaba - PTI - 2009.

Revista: Indústria News. 12a edição. 2009

Fascículos da série: Sorocaba 350 anos: Uma história ilustrada. $2^{\underline{a}}$ Ed. Jornal Cruzeiro do sul. 2004. Fundação Ubaldino do Amaral

Netgrafia

Banco Central do Brasil: www.bcb.gov.br

Fundação SEADE: www.seade.gov.br

Instituto Brasileiro de Geografia e Estatística (IBGE): www.ibge.gov.br Jornal Cruzeiro do Sul:

http://memoria.cruzeirodosul.inf.br/AcervoDigital WEB/AcervoPesquisa.jsf Prefeitura Municipal de Sorocaba: www.sorocaba.sp.gov.br 